\title{
The earliest evidence for Upper Paleolithic occupation in the Armenian Highlands at Aghitu-3 Cave
}

\author{
Andrew W. Kandel a, *, Boris Gasparyan b, Ethel Allué c, d, Gerlinde Bigga e, \\ Angela A. Bruch ${ }^{\mathrm{f}}$, Victoria L. Cullen ${ }^{\mathrm{g}}$, Ellery Frahm ${ }^{\mathrm{h}, \mathrm{i}}$, Robert Ghukasyan ${ }^{\mathrm{b}}$, \\ Ben Gruwier ${ }^{\mathrm{j}, \mathrm{k}}$, Firas Jabbour ${ }^{\mathrm{a}}$, Christopher E. Miller ${ }^{1}$, Andreas Taller ${ }^{\mathrm{m}}$, \\ Varduhi Vardazaryan ${ }^{\mathrm{m}}$, Davit Vasilyan ${ }^{\mathrm{e}, \mathrm{n}, \mathrm{o}}{ }^{\text {, Lior Weissbrod }}{ }^{\mathrm{p}}$
}

a The Role of Culture in Early Expansions of Humans, Heidelberg Academy of Sciences and Humanities at the University of Tübingen, Rümelinstr. 23, 72070 Tübingen, Germany

${ }^{\mathrm{b}}$ Institute of Archaeology and Ethnography, National Academy of Sciences, Charents St. 15, 0025 Yerevan, Armenia

c Institut Català de Paleoecologia Humana i Evolució Social, Zona educacional 4, Campus Sescelades URV (Edifici W3), 43007 Tarragona, Spain

d Àrea de Prehistòria, Universitat Rovira i Virgili, Av. Catalunya 35, 43002 Tarragona, Spain

e Department of Geology, University of Tübingen, Hölderlinstr. 12, 72074 Tübingen, Germany

${ }^{\mathrm{f}}$ The Role of Culture in Early Expansions of Humans, Heidelberg Academy of Sciences and Humanities at the Senckenberg Research Institute,

Senckenberganlage 25, 60325 Frankfurt, Germany

${ }^{g}$ University of Oxford, RLAHA, Dyson Perrins Building, Oxford, OX1 3QY, United Kingdom

h Yale Initiative for the Study of Ancient Pyrotechnology, Department of Anthropology, Yale University, 10 Sachem Street, New Haven, CT 06511, United States

${ }^{i}$ Department of Anthropology, Harvard University, Peabody Museum, 11 Divinity Avenue, Cambridge, MA 02138, United States

${ }^{\mathrm{j}}$ Department of Anthropology, Durham University, South Road, Durham, United Kingdom

${ }^{\mathrm{k}}$ Department of Experimental Anatomy, Vrije Universiteit Brussel, Laarbeeklaan 103, Jette, Belgium

${ }^{1}$ Department of Geoarchaeology, Institute of Archaeological Science, University of Tübingen, Rümelinstr. 23, 72070 Tübingen, Germany

${ }^{\mathrm{m}}$ Department of Early Prehistory and Quaternary Ecology, University of Tübingen, Schloss Hohentübingen, 72070 Tübingen, Germany

n JURASSICA Museum, Route de Fontenais 21, 2900 Porrentruy, Switzerland

${ }^{\circ}$ Department of Geosciences, University of Fribourg, Chemin du musée 6, 1700 Fribourg, Switzerland

${ }^{\mathrm{p}}$ Zinman Institute of Archaeology, University of Haifa, Mount Carmel, 31905, Israel

\begin{abstract}
With its well-preserved archaeological and environmental records, Aghitu-3 Cave permits us to examine the settlement patterns of the Upper Paleolithic (UP) people who inhabited the Armenian Highlands. We also test whether settlement of the region between $\sim 39-24,000$ cal BP relates to environmental variability. The earliest evidence occurs in archaeological horizon (AH) VII from $~ 39-36,000$ cal BP during a mild, moist climatic phase. AH VI shows periodic occupation as warm, humid conditions prevailed from $\sim 36-32,000$ cal BP. As the climate becomes cooler and drier at $\sim 32-29,000$ cal BP (AH V-IV), evidence for occupation is minimal. However, as cooling continues, the deposits of AH III demonstrate that people used the site more intensively from $\sim 29-24,000$ cal BP, leaving behind numerous stone artifacts, faunal remains, and complex combustion features. Despite the climatic fluctuations seen across this 15,000-year sequence, lithic technology remains attuned to one pattern: unidirectional reduction of small cores geared towards the production of bladelets for tool manufacture. Subsistence patterns also remain stable, focused on medium-sized prey such as ovids and caprids, as well as equids. AH III demonstrates an expansion of social networks to the northwest and southwest, as the transport distance of obsidian used to make stone artifacts increases. We also observe the addition of bone tools, including an eyed needle, and shell beads brought from the east, suggesting that these people manufactured complex clothing and wore ornaments. Remains of micromammals, birds, charcoal, pollen, and tephra relate the story of environmental variability. We hypothesize that UP behavior was linked to shifts in demographic pressures and climatic changes. Thus, by combining archaeological and environmental data, we gain a clearer picture about the first UP inhabitants of the Armenian Highlands.
\end{abstract}

\footnotetext{
* Corresponding author.

E-mail address: a.kandel@uni-tuebingen.de (A.W. Kandel).
} 


\section{Introduction}

Until recently, the Paleolithic record of the Armenian Highlands was scarcely known, so that questions relating to settlement patterns, demographic dynamics, and climatic background could not be answered. Over the last two decades, archaeological research in the Republic of Armenia has intensified thanks to the efforts of the Institute of Archaeology and Ethnography (IAE), National Academy of Sciences (Gasparyan and Arimura, 2014). Several international research groups have been working to gain new insights into the prehistory of the region. For example, a series of open-air sites document Lower and Middle Paleolithic occupations, especially in northern Armenia (e.g., Dolukhanov et al., 2004; Aslanian et al., 2006; Kolpakov, 2009; Egeland et al., 2010; Gasparyan et al., 2014a).

Much of the latest research focuses on the Middle Paleolithic (MP) settlement of the Armenian Highlands, providing well excavated and dated assemblages. These studies cover the earliest MP at Nor Geghi-1 open-air site (Adler et al., 2014), the middle MP at Hovk-1 Cave (Pinhasi et al., 2008; Bar-Oz et al., 2012); the late MP at Lusakert-1 Cave, Barozh-12 open-air site, and Angeghakot-1 Rockshelter (Liagre et al., 2006; Adler et al., 2012; Gasparyan et al., 2014b), and the latest MP at Kalavan-2 open-air site (Ghukasyan et al., 2011). Taken together, these projects provide a solid foundation for understanding the course of MP settlement in Armenia.

While the MP is comparatively well known, stratified Upper Paleolithic (UP) sequences are rare in the Armenian Highlands. Gasparyan et al. (2014c) determined that most UP sites mentioned in the Soviet literature in fact consist of Neolithic-Chalcolithic openair workshops located near obsidian sources. Until now, only one UP occupation dating to $18-16,000$ cal $\mathrm{BP}$-and designated as Epigravettian by the excavators-is documented at the Kalavan-1 openair site (Montoya et al., 2013; Tornero et al., 2016). Therefore, the discovery in 2009 of a UP sequence at Aghitu-3 Cave (Fig. 1a) sheds the first light on development of the UP in this region.

Immediately to the north, the Republic of Georgia remains a focus for research into the earliest settlement of hominins outside of Africa (Gabunia et al., 2002; Vekua et al., 2002; Lordkipanadze, 2005; Lordkipanadze et al., 2013). Georgia also provides important evidence regarding the demise of the Neanderthals and the advent of modern humans at cave sites such as Ortvale Klde, Dzudzuana, and Satsurblia (Nioradze and Otte, 2000; Bar-Oz and Adler, 2005; Bar-Yosef et al., 2006, 2011; Adler et al., 2008; Pinhasi et al., 2014). Adler et al. (2008) suggest the last Neanderthals survived at Ortvale Klde until about $43-42,000$ cal BP, while the first presumably modern humans entered the region between 42 and $39,000 \mathrm{cal}$ BP. Looking south and southwest to the Zagros and the Syrian desert, we draw attention to a growing body of research examining the early UP settlement of Iran, Iraq, and central Syria. At sites such as Yafteh, Ghar-e Boof, Garm Roud 2, Shanidar, and Umm el Tlel, researchers posit the presence of UP technology by 40-35,000 cal BP (Olszewski and Dibble, 1994; Boëda et al., 2006; Chevrier et al., 2006; Otte et al., 2011, 2012; Tsanova, 2013; Ghasidian, 2014).

In this paper, we present new data from archaeological, environmental, and geological analyses at Aghitu-3 Cave located in the Syunik Province of southern Armenia (Fig. 1b). We summarize the results of the 2009-2016 field seasons to provide a comprehensive framework for understanding the first UP occupation of the Armenia Highlands starting about 39,000 years ago. Additionally, we examine variations in the behavior of the earliest inhabitants of this region and their responses to environmental changes over the next 15,000 years. We then synthesize these results and compare them to contemporaneous sites in the region. This work fills a geographic gap in the record of expansion of UP technologies and complex human behaviors, within a key region for current research on modern human dispersal patterns.

\section{Background}

The Tübingen-Armenian Paleolithic Project (TAPP) began in 2008 as a joint endeavor between the IAE and the Heidelberg Academy of Sciences and Humanities at the University of Tübingen. TAPP's goal is to find and excavate Paleolithic sites in the Armenian Highlands along the Vorotan River. The SE-NW-oriented valley of the Vorotan represents a significant axis for movement through the region because the surrounding Zangezur and Syunik ranges rise to $3850 \mathrm{~m}$, channeling the movement of humans and game through this natural corridor. TAPP conducted its systematic surveys along the Vorotan, mapping onto a paleoenvironmental, geomorphological, and chronological framework for the region established by Ollivier et al. (2010).

The valley of the Vorotan River is situated within a topographically and climatologically diverse region between the maritime realm of Western Eurasia and the continental climate of Central Eurasia. The Vorotan River valley is influenced by both its high altitude and relatively eastern position. Thus, its modern-day climate is continental with considerable seasonality in temperatures. Monthly mean temperatures range from $20.2^{\circ} \mathrm{C}$ in summer to $-3.8^{\circ} \mathrm{C}$ in winter with an annual average of $8.5^{\circ} \mathrm{C}$. The meteorological station in the town of Sisian reports moderate annual precipitation of $532 \mathrm{~mm}$. Most of the rain falls during the spring, whereas summers are generally more dry (http://climate-data.org/ Climate-data.org, 2017). Based on the Köppen-Geiger system, the regional climate is classified as $\mathrm{Dfb}$-cold, without a dry season, and with warm summers (Peel et al., 2007). Vegetation in the valley is dominated by mountain meadows and steppes classified as "Preand Transcaucasian Stipa-steppes" according to the European Vegetation Map (Bohn et al., 2004). Only on north-facing slopes do small patches of East Transcaucasian altimontane oak forests (with Quercus macranthera) persist due to locally more humid microclimates.

During TAPP's first field season, the team conducted surveys near Sisian. In the nearby village of Aghitu, the team noted several caves at the base of a flat-topped, basalt massif that rises $25 \mathrm{~m}$ above the surrounding landscape (Fig. 2a). The massif covers $\sim 2$ ha and represents the distal end of a lava flow that erupted from Mt. Bugdatapa 126-111 ka (Ollivier et al., 2010). In test pits around the massif, a French team reported Medieval artifacts (Chataigner, 2003), while atop the massif, Kroll (2006) documented Middle Bronze Age, Hellenistic, and Medieval ceramics.

During our survey, we noted laminar artifacts and fossil bone fragments lying on the surface of the largest cave measuring $11 \mathrm{~m}$ deep, $18 \mathrm{~m}$ wide, and $6 \mathrm{~m}$ high (Fig. 2b). Located at an elevation of $1601 \mathrm{~m}, 115 \mathrm{~m}$ above the Vorotan River, we designated the site Aghitu-3 Cave (N 39.5138, E 46.0822) according to local convention. As we expanded and deepened a French test pit in June 2009, we discovered stratified deposits. We returned every year thereafter to excavate the site and analyze the finds. This paper summarizes the results of the Paleolithic excavations through the end of the 2016 season.

\subsection{Excavation methods}

After establishing a measuring grid with letters designating the $\mathrm{x}$-axis and numbers denoting the $\mathrm{y}$-axis (Fig. 3), we excavated the site in square meter units sub-divided into quarter meters, each with a volume of $10 \mathrm{~L}$. We piece-plotted all finds $>2 \mathrm{~cm}$ and charcoal pieces $>1 \mathrm{~cm}^{3}$ with a Leica total station, recording data on a field laptop using EDM for Windows (Dibble and McPherron, 1996). 
We dry-screened all excavated sediment using 5 and $2 \mathrm{~mm}$ sieves, adding $1 \mathrm{~mm}$ sieves for a selected column of microfaunal samples. This method allowed for optimal collection of small finds owing to the dry, friable nature of the silty sediments. The crew collected micromorphological sediment blocks and loose soil samples to gain geological information and recover botanical data for environmental reconstruction. We drew the main profiles at $2 \mathrm{~m}$ intervals.

The excavations inside the cave were enlarged in successive $2 \times 2 \mathrm{~m}$ blocks to create steps that facilitated access to the deepest part of the pit. As the excavations expanded beyond the dripline of the cave, we encountered an undisturbed late Hellenistic stone tomb containing seven individuals with grave goods and further stone constructions. At the end of the 2016 season, the Paleolithic excavation covered $40 \mathrm{~m}^{2}$ inside the cave, while the tomb excavation encompassed more than $60 \mathrm{~m}^{2}$ outside.

\subsection{Stratigraphy}

Based on our excavation of more than $5.5 \mathrm{~m}$ of deposits, we identified 12 geological horizons $(\mathrm{GH})$ that contain seven archaeological horizons (AH). Since Kandel et al. (2014) describe the stratigraphic sequence down to $\mathrm{AH} \mathrm{VI}$, we provide an overview here (Table 1; Fig. 4). The surface horizon AH I (GH 1) is unconsolidated brownish-gray ashy silt, containing plentiful modern debris and Middle Bronze Age, Hellenistic, and Medieval ceramics as well as Paleolithic artifacts and mineralized faunal remains (Kandel et al., 2011). AH II (GH 2) is a compact gray silt with noticeably fewer finds of the types mentioned in AH I. Starting with AH III (GH 3), evidence for UP occupation is clear. The sediment is a compact yellowish brown silt, intercalated with variable amounts of horizontal lying, platy basalt. Four largely continuous bands (AH IIIa-d), each about 2-5 cm thick, contain abundant lithics, fauna, and charcoal. Large, well-preserved combustion features are clearly visible. For the purpose of this paper, we consider layers AH IV (GH 4-7) and AH V ( GH 8) sterile because they yielded so few finds. GH 8 is notable for two $2-10 \mathrm{~cm}$ thick volcanic ash layers, an upper gray tephra (GH 8a/AH Va) and a lower black tephra (GH 8d/AH Ve), both with sharp contacts. GH 9 is a massive rock fall that appears to have acted as a trap, allowing the overlying sedimentary sequence to accumulate inside the cave without eroding out. $\mathrm{AH} \mathrm{VI} \mathrm{(GH} \mathrm{10)} \mathrm{is}$ a brown clayey silt with very little basalt debris. This layer contains isolated clusters of lithics, fauna, and charcoal concentrated around small, intact combustion features. AH VII (GH 11) coarsens with depth, grading from clayey silt to silty sand, while cobbles and boulders become more frequent. This layer yielded scattered lithic and faunal remains with occasional pieces of charcoal. An archaeologically sterile lag deposit at the base of AH VII is rich in microvertebrates, including micromammals, birds, and fish. Finally, GH 12 appears to be sterile volcanoclastic sediment, marking the base of the excavated sequence. We interpret the deepest geological layer as the paleo-landscape surface before basalt covered it 126-111,000 years ago (Ollivier et al., 2010).

\subsection{Dating}

We sent 33 samples ( 12 bone and 21 charcoal) from the Paleolithic horizons to the Leibniz Laboratory in Kiel (KIA) and the Curt Engelhorn Centre for Archaeometry in Mannheim (MAMS) for AMS radiocarbon dating. Results are presented in Table 2 and calibrated using OxCal version 4.2.4 (Bronk Ramsey, 2013; Reimer et al., 2013). The results date the AH VII occupation from about 39 to $36,000 \mathrm{cal}$ $\mathrm{BP}$, while AH VI ranges from about 36 to $32,000 \mathrm{cal} \mathrm{BP}$. The mostly sterile AH V and IV date between 32 and 29,000 cal BP, and AH III yields ages from 29 to 24,000 cal BP (Fig. 5). The number of radiocarbon dates and their consistency across a $5.5 \mathrm{~m}$ stratigraphic
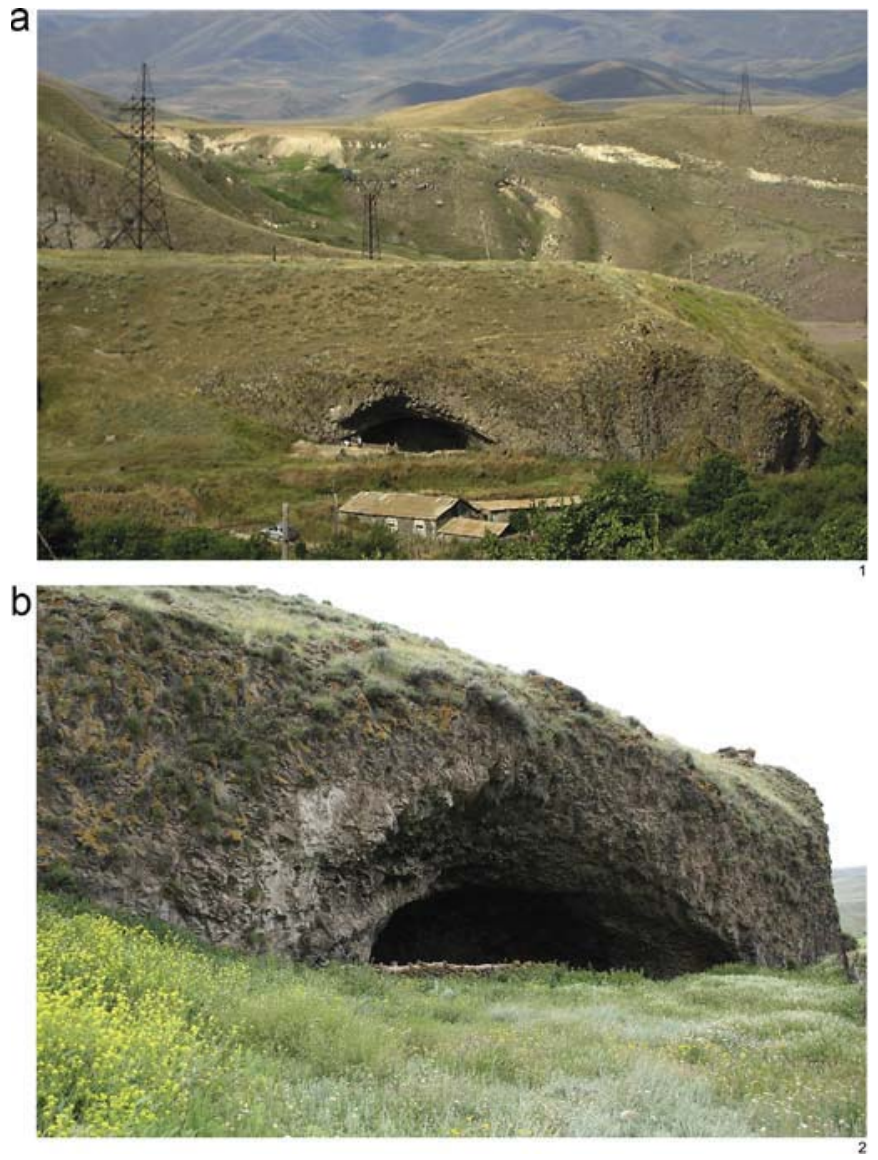

Figure 2. Photos of Aghitu-3 showing: a) basalt massif, looking SW; b) cave entrance, looking W. (Photos: A. Kandel).

sequence suggest a fine-grained chronometry that can be used to examine human activities and their relationship to environmental change.

\section{Micromorphology and site formation}

To investigate site formation processes at Aghitu-3, we collected 18 block samples for micromorphological analysis. The blocks were indurated in a polyester resin and then sliced into $3 \times 5 \mathrm{~cm}$ chips for thin sectioning. The thin sections were examined using the naked eye and petrographic microscopes under plane polarized light (PPL), cross-polarized light (XPL), oblique incident light (OIL), and blue-light fluorescence at magnifications ranging from $20-200 \times$, following descriptive and analytical guidelines established by Bullock et al. (1985), Courty et al. (1989), and Stoops (2003).

Through petrographic analyses of thin sections, we are able to determine not only the composition of sedimentary components but also the spatial and stratigraphic relationship between grains, aggregates, voids, and post-depositional features. Micromorphology allows us to identify the varying roles that humans, animals, and geological forces played in the accumulation of sediments at the site, as well as the processes that acted to modify these deposits following their accumulation. A micromorphological approach is especially informative at Aghitu-3 because of the cave's basaltic nature. The site expands our knowledge of formation processes within caves and rockshelters beyond those found in limestone or sandstone contexts.

The coarse fraction of the sediments at Aghitu-3, here defined as $>5 \mu \mathrm{m}$, is largely dominated by rock fragments of volcanic origin. 
PLAN OF AGHITU-3 CAVE (1:100)
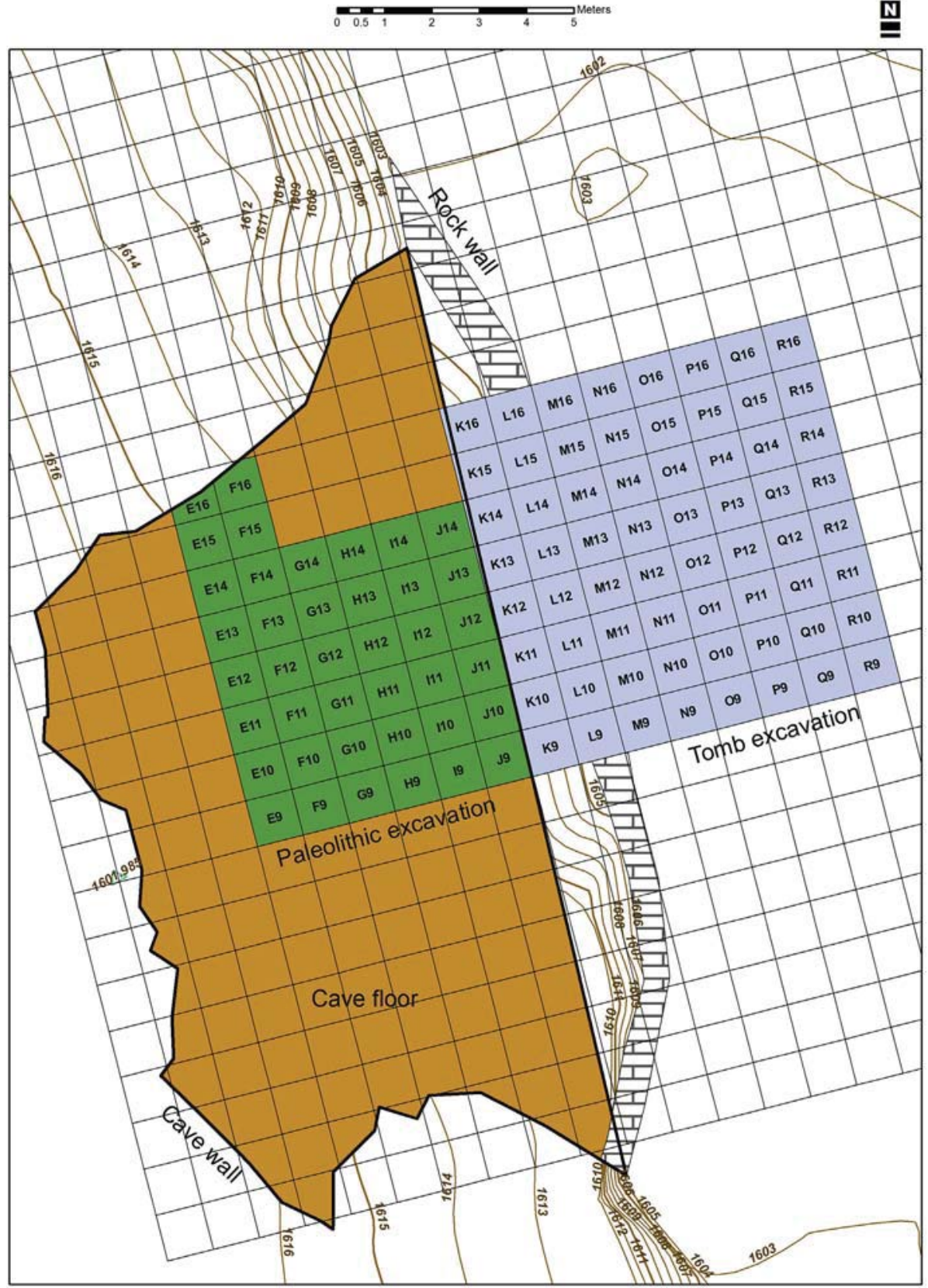

Figure 3. Plan of Aghitu-3 showing the Paleolithic excavation in green and the tomb excavation in light blue. (Illustration: D. Arakelyan). (For interpretation of the references to colour in this figure legend, the reader is referred to the web versionof this article).

These include angular, platy clasts of basalt, originating from the cave ceiling and walls (i.e., éboulis), and rounded gravel-sized clasts of pumice, some of which appear weathered. While the basaltic éboulis is found throughout the stratigraphic sequence, it is particularly common in AH III, where it appears horizontally to subhorizontally oriented. The silt-sized fraction is composed of rare quartz grains as well as crystallitic tephra, which are common in $\mathrm{AH}$ Va and Ve.

The fine fraction is largely composed of a highly birefringent clay, likely derived from the weathering of the local basaltic bedrock. Some of the fine fraction appears calcareous, which may ultimately derive from local lacustrine deposits (Ollivier et al., 2010); however, the presence of a rounded fragment of tufa and calcareous crusts, some of which adhere to basaltic fragments of bedrock, suggest that the carbonate may have formed within or very near the cave, possibly within a spring. The fine fraction exhibits graded bedding in some samples, particularly in AH V and below, suggesting that the fine fraction entered the cave from the entrance through low-energy, surface flow. In other samples, fine sedimentary structures appear to have been destroyed by bioturbation, as suggested by the presence of channel voids. Other deposits indicate laminar sheet flow across the site, which gently deposited fine sediments into the cave. The graded bedding is masked by the development of a lenticular microstructure, which is likely related to freeze-thaw processes (van Vliet-Lanoë et al., 1984). 
Table 1

Summary of archaeological $(\mathrm{AH})$ and geological $(\mathrm{GH})$ horizons listing sediment descriptions, archaeological attributions and age ranges.

\begin{tabular}{|c|c|c|c|c|c|c|c|}
\hline $\mathrm{AH}$ & GH & Sub-layers & $\begin{array}{l}\text { Area } \\
\text { excavated } \\
\left(\mathrm{m}^{2}\right)\end{array}$ & $\begin{array}{l}\text { Thickness } \\
\quad(\mathrm{cm})\end{array}$ & Sediment description & Archaeological materials & Age (cal BP) \\
\hline I & 1 & - & 40 & $10-20$ & $\begin{array}{l}\text { Gray, fine-grained ashy deposits with dung } \\
\text { layers }\end{array}$ & $\begin{array}{l}\text { Modern debris, ceramics from Middle Bronze } \\
\text { Age, Hellenistic and Medieval periods, includes } \\
\text { UP lithics and mineralized faunal remains }\end{array}$ & $<4000$ \\
\hline II & 2 & - & 40 & $10-20$ & Gray, fine-grained ashy deposits & Noticeably fewer modern finds than AH I & $<4000$ \\
\hline III & 3 & $a-d$ & 40 & $50-100$ & $\begin{array}{l}\text { Brown, fine-grained sediment with much platy } \\
\text { basalt }\end{array}$ & Plentiful UP lithics, fauna and charcoal & $29-24,000$ \\
\hline IV & $\begin{array}{l}4 \\
5 \\
6 \\
7\end{array}$ & $\begin{array}{l}- \\
- \\
- \\
\mathrm{a}-\mathrm{c}\end{array}$ & 12 & $\begin{array}{l}20-35 \\
10-20 \\
5-15 \\
20-30\end{array}$ & $\begin{array}{l}\text { Light brown, coarse-grained deposits with } \\
\text { many rockfalls and much platy basalt }\end{array}$ & Almost sterile & $30-29,000$ \\
\hline V & 8 & $\mathrm{a}-\mathrm{e}$ & 12 & $20-30$ & $\begin{array}{l}\text { Brown, fine-grained sediments with two (gray } \\
\text { and black) tephra sub-layers (8a, 8e) }\end{array}$ & Almost sterile & $32-30,000$ \\
\hline- & 9 & - & 12 & $0-150$ & Massive rockfall & Sterile & - \\
\hline VI & 10 & - & 12 & $200-250$ & $\begin{array}{l}\text { Brown, fine-grained with very little basalt } \\
\text { debris }\end{array}$ & Concentrations of UP lithics, fauna and charcoal & $36-32,000$ \\
\hline VII & 11 & $a-b$ & 6 & $100-150$ & Reddish-brown, coarse-grained sediments & Scattered finds of UP lithics, fauna and charcoal & $39-36,000$ \\
\hline- & 12 & - & 1 & $>20$ & Purple coarse-grained volcanoclastic sediments & Sterile & $>126,000$ \\
\hline
\end{tabular}

Anthropogenic input to the sediments at Aghitu-3 is largely represented by several features, likely related to human use of fire. Micromorphological analysis has so far identified three types of features, seemingly related to varying states of preservation. Type 1 exhibits the classic association of a reddened substrate overlain by charcoal and ash and likely represents an intact combustion feature, for example, in AH VI. Type 2 is composed of a reddened substrate but lacks any overlying ash or charcoal, most common in AH III. It is possible that the reddening relates to heat alteration, but both charcoal and ash were eroded away. Type 3 consists of relatively thin $(\leq 1 \mathrm{~cm})$ layers of charcoal without any associated reddened substrate, seen mainly in AH III. This type of feature likely formed as geological or anthropogenic processes laterally displaced charcoal from a hearth.

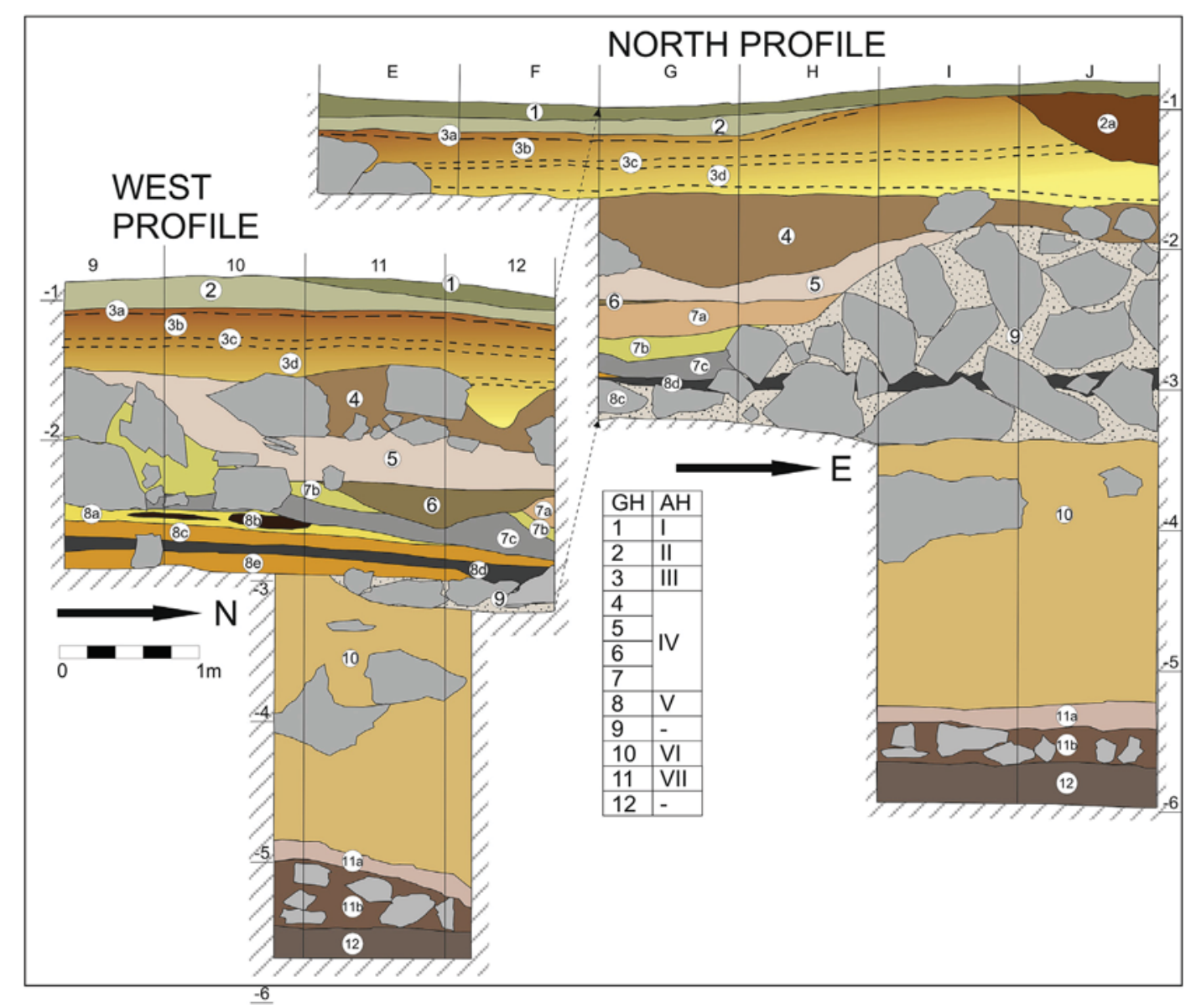

Figure 4. Drawings of the W and N profiles of Aghitu-3 showing relationship of geological (GH) and archaeological horizons (AH). (Illustration: A. Kandel). 
Table 2

Summary of radiocarbon dating results from Kiel and Mannheim calibrated using OxCal 4.2.4 (Bronk Ramsey, 2013; Reimer et al., 2013) sorted first by AH and then by depth.

\begin{tabular}{|c|c|c|c|c|c|c|c|c|c|c|c|}
\hline Lab ID & Material & Age BP & + StDev & -StDev & cal BP $(1 \sigma)$ & cal BP $(2 \sigma)$ & Square & Find & $\mathrm{AH}$ & $\mathrm{Z}(\mathrm{m})$ & Identification \\
\hline KIA-48939 & Charcoal & 20450 & 100 & 100 & $24794-24399$ & $25005-24275$ & $\mathrm{H} 14$ & 64 & IIIa & -1.10 & Betula \\
\hline KIA-48938 & Bone & 20540 & 90 & 90 & $24909-24533$ & $25095-24401$ & $\mathrm{H} 13$ & 68 & IIIa & -1.10 & medium-large (sc3), long bone \\
\hline KIA-43242 & Charcoal & 22900 & 180 & 180 & $27433-27080$ & $27577-26759$ & $\mathrm{~F} 11$ & 283 & IIIb & -1.09 & Salix \\
\hline KIA-43241 & Charcoal & 22630 & 300 & 300 & $27275-26600$ & $27493-26236$ & E12 & 262 & IIIb & -1.19 & Populus/Salix \\
\hline KIA-46653 & Charcoal & 24060 & 120 & 120 & $28244-27912$ & $28433-27798$ & E9 & 19 & IIIb & -1.23 & Hippophae rhamnoides \\
\hline KIA-43238 & Bone & 23140 & 130 & 130 & $27557-27321$ & $27670-27185$ & F12 & 425 & IIIc & -1.31 & Ovis/Capra, metatarsal \\
\hline KIA-46652 & Charcoal & 23490 & 170 & 170 & $27776-27526$ & $27904-27390$ & E10 & 43 & IIIC & -1.42 & Salix \\
\hline KIA-43243 & Charcoal & 23880 & 150 & 150 & $28070-27764$ & $28305-27664$ & F12 & 311 & IIId & -1.37 & deciduous, indet \\
\hline KIA-43240 & Bone & 23960 & 120 & 120 & $28125-27830$ & $28328-27733$ & F12 & 623 & IIId & -1.48 & Equus, radius $\mathrm{R}$ \\
\hline KIA-46654 & Charcoal & 24840 & 140 & 140 & $29025-28694$ & $29265-28550$ & E11 & 59 & IIId & -1.53 & Hippophae rhamnoides \\
\hline KIA-48945 & Bone & 23690 & 135 & 135 & $27885-27665$ & $28034-27548$ & $\mathrm{H} 14$ & 360 & IIId & -1.85 & Equus, rib \\
\hline KIA-48941 & Charcoal & 24420 & 150 & 150 & 28659-28296 & 28789-28076 & H14 & 376 & IIId & -1.90 & Hippophae rhamnoides \\
\hline KIA-39640 & Charcoal & 27110 & 170 & 160 & $31222-30999$ & $31334-30874$ & G11 & 91 & $\mathrm{Vb}$ & -2.38 & Salix \\
\hline MAMS-23306 & Bone & 25760 & 90 & 90 & $30176-29745$ & $30351-29563$ & $\mathrm{I} 12$ & 234 & Ve & -2.76 & Canis, cranium \\
\hline KIA-39642 & Bone & 27120 & 170 & 170 & $31227-31003$ & $31340-30879$ & G11 & 98 & Ve & -2.77 & Canis, radius L prox \\
\hline MAMS-23057 & Bone & 27680 & 110 & 110 & $31516-31296$ & $31649-31181$ & $\mathrm{~J} 12$ & 355 & VI & -3.10 & Canis, humerus \\
\hline KIA-39643 & Bone & 28680 & 200 & 200 & $33165-32456$ & $33430-31987$ & G11 & 129 & VI & -3.50 & Ovis, femur \\
\hline KIA-46655 & Charcoal & 30380 & 590 & 550 & $34894-33890$ & $35667-33485$ & $\mathrm{I} 10$ & 38 & VI & -3.73 & ring-porous, indet \\
\hline KIA-46656 & Charcoal & 30120 & 280 & 270 & $34421-33926$ & $34680-33739$ & H11 & 58 & VI & -3.81 & Hippophae rhamnoides \\
\hline KIA-46657 & Charcoal & 30250 & 220 & 210 & $34485-34059$ & $34689-33885$ & H11 & 66 & VI & -3.88 & Hippophae rhamnoides \\
\hline KIA-39641 & Charcoal & 30210 & 180 & 170 & $34421-34043$ & $34613-33895$ & G10 & 124 & VI & -4.04 & Betula \\
\hline KIA-46658 & Charcoal & 31330 & 260 & 250 & $35495-34924$ & $35811-34696$ & G10 & 32 & VI & -4.41 & Populus/Salix \\
\hline KIA-50267 & Charcoal & 31800 & 270 & 270 & $36030-35405$ & $36267-35087$ & H11 & 207 & VI & -4.87 & Hippophae rhamnoides \\
\hline KIA-50266 & Charcoal & 31540 & 190 & 190 & $35650-35165$ & $35913-34954$ & H11 & 200 & VI & -4.88 & Hippophae rhamnoides \\
\hline KIA-50263 & Bone & 33780 & 870 & 790 & $39122-36901$ & $40307-36145$ & G10 & 199 & VII & -4.70 & medium (sc2), long bone \\
\hline KIA-50268 & Bone & 30630 & 720 & 660 & $35785-34374$ & $36724-33809$ & $\mathrm{H} 11$ & 305 & VII & -5.22 & medium ( $\mathrm{sc} 2$ ), long bone \\
\hline KIA-50272 & Charcoal & 33900 & 370 & 370 & $38831-37878$ & $39266-37117$ & H11 & 350 & VII & -5.32 & Hippophae rhamnoides \\
\hline KIA-50270 & Charcoal & 33600 & 470 & 470 & $38572-37262$ & $39021-36553$ & H11 & 341 & VII & -5.38 & Hippophae rhamnoides \\
\hline KIA-50269 & Charcoal & 34220 & 320 & 320 & $39073-38400$ & $39587-38032$ & $\mathrm{H} 11$ & 334 & VII & -5.40 & Nitraria \\
\hline KIA-50271 & Bone & 33260 & 860 & 780 & $38500-36436$ & $39721-35626$ & H11 & 347 & VII & -5.46 & Ovis, tibia \\
\hline KIA-50265 & Bone & 33990 & 890 & 800 & $39508-37208$ & $40576-36291$ & G11 & 202 & VII & -5.48 & Ovis/Capra, metapodial \\
\hline KIA-50274 & Charcoal & 32890 & 280 & 280 & $37385-36441$ & $37998-36234$ & H11 & 377 & VII & -5.58 & Hippophae rhamnoides \\
\hline KIA-50273 & Charcoal & 31360 & 270 & 270 & $35535-34942$ & $35865-34709$ & $\mathrm{H} 11$ & 371 & VII & -5.59 & Hippophae rhamnoides \\
\hline
\end{tabular}

\section{Tephra}

Two samples, the upper gray tephra (sample AG3-8A) and the lower black tephra (sample AG3-8D), were sieved through $25 \mu \mathrm{m}$ mesh and density-separated, dried, and mounted in epoxy resin blocks. Prior to elemental analysis, the blocks were ground and polished to expose flat surfaces and carbon-coated. Shards from each sample were analyzed with a four-spectrometer JEOL-8600 electron microprobe, housed at the University of Oxford's Research Laboratory for Archaeology and the History of Art, using a $15 \mathrm{kV}$, $6 \mathrm{nA}, 10 \mu \mathrm{m}$ beam. The instrument was calibrated for 11 elements using a suite of mineral standards. Reference glasses (MPI-DING; Jochum et al., 2006) were analyzed with the tephra samples to assess and monitor precision and accuracy.

In both tephra deposits, the shards range from $\sim 40-120 \mu \mathrm{m}$ and are rich in microcrystals. The shards are irregular in form and contain expanded vesicles. Despite the color differences observed in the profile, the glass shards from both tephra layers are predominantly trachy-andesite and similar in appearance and composition. The shards have $55.95-61.06 \mathrm{wt}$. \% $\mathrm{SiO}_{2}$ and are high in $\mathrm{MgO}$ (1.38-6.91 wt. \%) and $\mathrm{FeO}$ (3.95-8.29 wt. \%) ( $n=15$ for each sample; Fig. 6). As the tephra deposits are relatively thick $(2-10 \mathrm{~cm})$, it seems unlikely that they traveled far. The most likely source is from local volcanoes of the Syunik Highlands. Thus, the presence of these two visible tephra layers in AH V suggests that explosive volcanic activity occurred in the region $\sim 31,000 \mathrm{cal} B P$, based on the radiocarbon dating of charcoal in $\mathrm{AH} \mathrm{Vb}$ (Table 2). While trachy-andesitic volcanic products are also known from the Gegham volcanic range in central Armenia, $150 \mathrm{~km} \mathrm{NW}$ (Arutyunyan et al., 2007; Lebedev et al., 2011), the glass chemistry of the proximal deposits remains uncharacterized and cannot be correlated to known eruptions.

\section{Overview of archaeological finds}

In the following sections, we present results from the Paleolithic excavations of Aghitu-3 but exclude finds from mixed or uncertain stratigraphic provenience (Table 3 ). This study is based on the analysis of 4980 chipped stone artifacts and 2291 larger mammal remains. It includes 2543 micromammal remains, 261 bird bones, 49 fish and other small vertebrates, and 2073 charcoal samples. The analysis incorporates 171 soil samples for geological testing and 62 soil samples for palynological evaluation.

\subsection{Lithic artifacts}

We conducted attribute analysis of 4980 knapped lithic artifacts $>5 \mathrm{~mm}$ at the IAE laboratories in Yerevan following methods and definitions outlined in Auffermann et al. (1990) and Hahn (1993). Overall AH III represents $89 \%(n=4452)$ of the analyzed assemblage, while $7 \%(n=355)$ of the finds come from AH VI and $3 \%$ $(n=155)$ come from AH VII (Table 3$)$. Since the artifacts from AH V and IV represent $0.4 \%(n=18)$ of the assemblage, we exclude these layers from further discussion but present relevant data in the tables. It is also important to keep the sheer numerical dominance of $\mathrm{AH}$ III in mind when ascribing significance to the behavioral patterns we describe.

Obsidian dominates the lithic assemblage (Table 4) with about $84 \%(n=4211)$, followed by chert with $15 \%(n=751)$. The few remaining pieces $(0.4 \%)$ are igneous in origin, mainly dacite $(n=16)$ and basalt $(n=2)$. The distribution of raw materials differs among the layers, with AH VI showing the lowest share of obsidian ( $n=246)$ at $69 \%$. The most common macroscopic variant of obsidian is translucent to smoky gray, glassy, and often banded or speckled. Other macroscopic varieties of obsidian include gray 


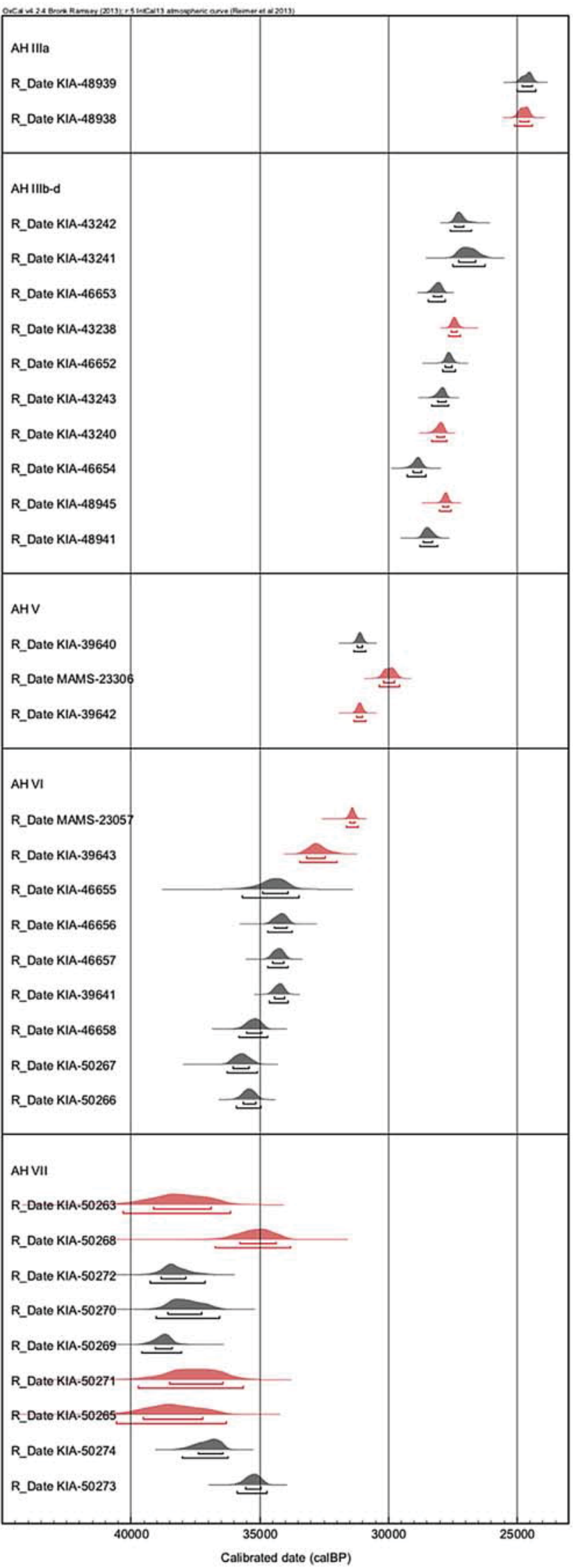

Figure 5. Plot of the calibrated radiocarbon ages from Table 2 using OxCal 4.2.4 (Bronk Ramsey, 2013; Reimer et al., 2013). Listed first by $\mathrm{AH}$ and then by depth. (Black $=$ charcoal; red $=$ bone). (For interpretation of the references to colour in this figure legend, the reader is referred to the web versionof this article).

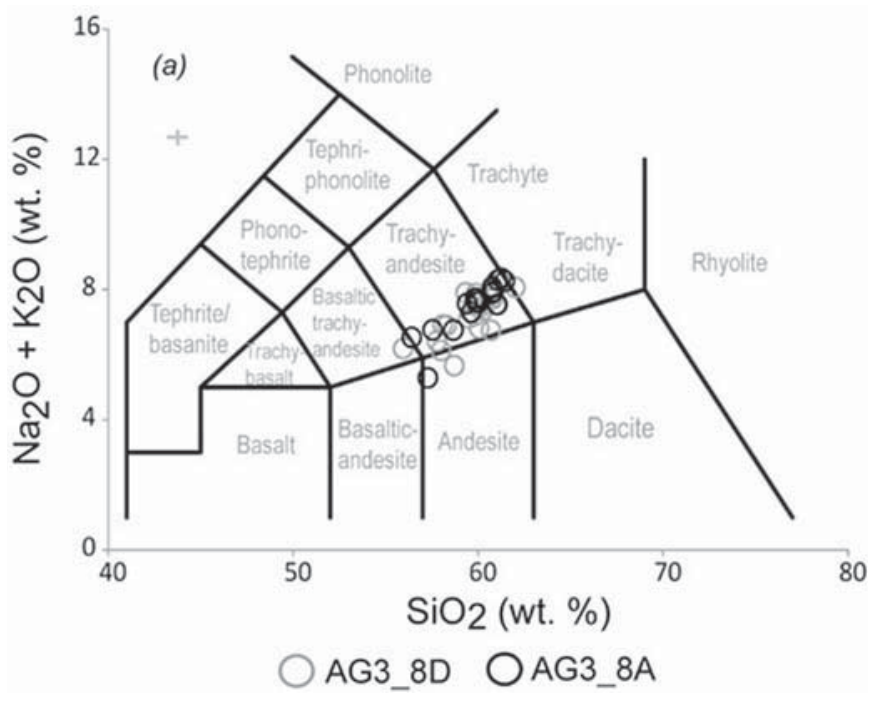

Figure 6. Glass compositions of visible tephra samples from Aghitu-3 layers AH Va (GH 8a) and $\mathrm{AH}$ Ve (GH 8d). Glasses are trachy-andesite in composition with both tephra layers showing the same compositional range. Circles represent error of $2 \sigma$.

Table 3

Summary of find categories reported in this paper, listed by $\mathrm{AH}$.

\begin{tabular}{lcccccc}
\hline Find category & AH III & AH IV & AH V & AH VI & AH VII & TOTAL \\
\hline Lithics & 4452 & 5 & 13 & 355 & 155 & 4980 \\
Macromammals & 1749 & 27 & 15 & 398 & 102 & 2291 \\
Micromammals & 456 & 162 & 96 & 898 & 931 & 2543 \\
Birds & 37 & 2 & 11 & 52 & 159 & 261 \\
Reptiles & 1 & - & - & - & - & 1 \\
Amphibians & 4 & - & - & - & 4 & 8 \\
Fish & 18 & - & - & - & 22 & 40 \\
Charcoal & 1655 & - & - & 283 & 135 & 2073 \\
Block samples & 11 & - & 1 & 5 & 1 & 18 \\
Soil samples & 103 & 7 & 8 & 28 & 25 & 171 \\
Pollen samples & 4 & 9 & 3 & 29 & 17 & 62 \\
\hline
\end{tabular}

matte and red-and-black banded opaque. However, the macroscopic traits of obsidian are poor indicators of their volcanic source (Frahm et al., 2014, Table 1). Thus, we used X-ray fluorescence (XRF) to chemically identify the various sources of obsidian, as presented in the next section.

After obsidian, chert is the other common lithic material at Aghitu (Table 4). The chert is of excellent knapping quality, very fine-grained, and comprising a broad spectrum of colors including brown, red, pink, yellow, gray, and white. Chert is most frequent in AH VI at 31\% ( $n=109)$. Geological maps indicate sources of chert near Brnakot, $9 \mathrm{~km}$ to the west, and near Goris, $22 \mathrm{~km}$ to the east. Our field surveys identified chert of poor quality in Brnakot, but it is dissimilar to that found at Aghitu-3. We did not find any chert cobbles in the gravel deposits along the Vorotan.

Table 4

Distribution of raw materials, showing percentage of obsidian and chert compared to the entire assemblage.

\begin{tabular}{lcccccc}
\hline Raw material & AH III & AH IV & AH V & AH VI & AH VII & TOTAL \\
\hline Obsidian & 3799 & 5 & 12 & 246 & 149 & 4211 \\
Chert & 637 & - & 1 & 109 & 4 & 751 \\
Volcanics (dacite, basalt) & 16 & - & - & - & 2 & 18 \\
TOTAL & 4452 & 5 & 13 & 355 & 155 & 4980 \\
\% Obsidian & $85 \%$ & $100 \%$ & $92 \%$ & $69 \%$ & $96 \%$ & $85 \%$ \\
$\%$ Chert & $14 \%$ & - & $8 \%$ & $31 \%$ & $3 \%$ & $15 \%$ \\
\hline
\end{tabular}


About 13\% ( $n=617)$ of all blanks show traces of cortex (Table 5), suggesting that people collected some of their raw materials from water-worn pebbles and cobbles. We assessed the degree to which the dorsal surface and butt of the blanks were covered in cortex, measured in increments of $10 \%$. The large sample size of AH III $(n=4199)$ affords the clearest picture, where $86 \%(n=3598)$ of the blanks show no cortex at all. While $14 \%(n=601)$ of blanks show some cortex, more than half of those pieces $(n=322)$ have low cortical coverage between 0 and 20\%. This trend is mirrored in the other layers as well. Thus the overwhelming majority of blanks are considered to represent a stage of reduction after the initial preparation of a cobble, likely during blank production. The low percentage of cortex also suggests that people maximized their use of lithic materials. Additionally, $4 \%$ of blanks exhibit naturally weathered fracture planes, which we associate with procurement directly from the outcrops. The relatively low prevalence of cortex and weathered fracture planes indicates that the assemblage is highly reduced. However, cortex and fracture planes provide just a glimpse of the story about which procurement strategies people preferred. This question can be better answered using other techniques (Frahm et al., 2016 and see below).

The assemblage (Table 6$)$ consists of $17 \%$ tools $(n=842)$, while cores comprise $2 \%(n=117)$. This disparity is clearest in AH III and VI, but less so in AH VII, where the low piece count clouds the interpretation. Laminar blanks (Table 7) comprise half of the entire assemblage $(n=2394)$, and about three-quarters of those are bladelets $(n=1742)$. Laminar blanks are at least twice as long as they are wide and have parallel sides (Inizan et al., 1999). Blades are defined as $\geq 10 \mathrm{~mm}$ in width, while bladelets are $<10 \mathrm{~mm}$ in width (see Hahn, 1977; Floss, 2013). No length criteria were imposed here. The trend toward laminar blanks is visible in all horizons, as is the

Table 5

Percentage of cortex coverage on the dorsal surface and butt of blanks measured in increments of $10 \%$. Percentage of cortical pieces indicates the proportion of blanks with cortical cover.

\begin{tabular}{lcccccc}
\hline $\begin{array}{l}\text { \% Cortex } \\
\text { coverage }\end{array}$ & AH III & AH IV & AH V & AH VI & AH VII & TOTAL \\
\hline 0 & 3598 & 4 & 13 & 328 & 140 & 4083 \\
$0-10$ & 212 & 1 & - & 3 & 1 & 217 \\
$10-20$ & 110 & - & - & 3 & 1 & 114 \\
$20-30$ & 80 & - & - & 1 & 2 & 83 \\
$30-40$ & 71 & - & - & - & 3 & 74 \\
$40-50$ & 54 & - & - & - & - & 54 \\
$50-60$ & 15 & - & - & - & - & 15 \\
$60-70$ & 13 & - & - & - & 1 & 14 \\
$70-80$ & 13 & - & - & - & - & 13 \\
$80-90$ & 9 & - & - & - & - & 9 \\
$90-100$ & 18 & - & - & - & - & 18 \\
100 & 6 & - & - & - & - & 6 \\
Total cortical & 601 & 1 & 0 & 7 & 8 & 617 \\
$\quad$ pieces & & & & & & \\
Total blanks & 4199 & 5 & 13 & 335 & 148 & 4700 \\
$\%$ Cortical pieces & $14.3 \%$ & $20.0 \%$ & $0.0 \%$ & $2.1 \%$ & $5.4 \%$ & $13.1 \%$ \\
\hline
\end{tabular}

Table 6

Distribution of lithic categories, showing percentage of tools and cores compared to the entire assemblage. For AH IV and V, percentages are omitted due to the small sample sizes. See text for further descriptions.

\begin{tabular}{lcccccc}
\hline Lithic category & AH III & AH IV & AH V & AH VI & AH VII & TOTAL \\
\hline Blanks (unretouched) & 3454 & 2 & 9 & 259 & 134 & 3858 \\
Tools & 745 & 3 & 4 & 76 & 14 & 842 \\
Cores & 110 & - & - & 3 & 4 & 117 \\
Angular debris & 143 & - & - & 17 & 3 & 163 \\
TOTAL & 4452 & 5 & 13 & 355 & 155 & 4980 \\
\% Tool & $17 \%$ & - & - & $21 \%$ & $9 \%$ & $17 \%$ \\
$\%$ Core & $2 \%$ & - & - & $1 \%$ & $3 \%$ & $2 \%$ \\
\hline
\end{tabular}

Table 7

Distribution of blank categories, showing ratio of bladelets to blades.

\begin{tabular}{lcccccc}
\hline Blank category & AH III & AH IV & AH V & AH VI & AH VII & TOTAL \\
\hline Flakes & 2139 & 1 & 6 & 106 & 54 & 2306 \\
Blades & 599 & 2 & 3 & 25 & 23 & 652 \\
Bladelets & 1461 & 2 & 4 & 204 & 71 & 1742 \\
Sub-total laminar & 2060 & 4 & 7 & 229 & 94 & 2394 \\
TOTAL & 4199 & 5 & 13 & 335 & 148 & 4700 \\
Bladelets: Blades & 2.4 & 1.0 & 1.3 & 8.2 & 3.1 & 2.7 \\
\hline
\end{tabular}

emphasis on bladelet production, suggesting that these products played an important role throughout the sequence (Figs. 7-9).

An analysis of the dimensions of complete bladelets (Table 8) highlights their small size. Average length decreases over time from $33.1 \pm 18.8 \mathrm{~mm}$ in AH VII to $25.7 \pm 11.7 \mathrm{~mm}$ in AH III. The average width shows no trend, ranging from $7.0 \pm 2.9 \mathrm{~mm}$ in $\mathrm{AH}$ VI to $9.0 \pm 4.4 \mathrm{~mm}$ in AH III. In fact the range of the standard deviation is greater than the magnitude of the observed changes. Furthermore, the median value does not vary in accordance with the average, suggesting that the numerical decrease in length is not a robust trend.

The selection of laminar blanks (Figs. 7-9) used in tool production (Table 9$)$ is high at $68 \%(n=570)$, supporting that these were the intended products, and bladelets dominate $(n=488)$. Even more striking, two categories of tools, laterally retouched and backed bladelets, together represent $92 \%(n=448)$ of the bladelet toolkit. Laterally retouched bladelets $(n=299)$ show fine, non-invasive retouch on more than half of at least one lateral edge. Abruptly (invasively) retouched and fully backed bladelets $(n=149)$ constitute the next most important category of bladelet tools. We are investigating whether these bladelet tools represent a spectrum ranging from finely retouched to fully backed bladelets. The next most common tool types are burins, scrapers, and denticulated pieces. Although these tools are usually associated with flakes, they are far less common than the laterally retouched and backed bladelets. This trend is clearest in AH III, but also seems to apply to the other layers where the sample numbers are smaller.

Cores have a minimum of three blank removals (Figs. 7-9), with the exception of initial cores, which are tested pieces. Core fragments are broken cores showing a degree of organization, while angular debris consists of shatter or chunks $\geq 10 \mathrm{~mm}$ lacking a clearly recognizable dorsal and ventral surface. While the proportion of cores is low, their technological signature is clear (Table 10). In AH III, unidirectional platform cores predominate $(n=66)$, followed by bidirectional $(n=19)$ and multidirectional $(n=6)$ cores with three or more platforms. In cases where more than one platform is present, unidirectional logic prevails, implying that blank production was consistent and standardized.

The unidirectional cores are mostly small and highly reduced, with an average length of $24.9 \pm 8.4 \mathrm{~mm}$. Compared to the average length of the bladelets, the cores are smaller than their products. This observation further supports the idea that the cores are highly reduced and that raw material was conserved. We recorded technical pieces, such as crested blades and bladelets as well as core tablets and overshots, all of which indicate that cores were actively shaped and rejuvenated on site. These findings are consistent with the maintenance of a primary mode of reduction aimed at the manufacture of bladelets for tool production. This mode of production is remarkable in that its presence begins in $\mathrm{AH}$ VII and continues through AH III.

We note one important exception in the lowest layer, AH VII (Fig. 9), with the caveat of its low find count and few diagnostic pieces. Based on two cores, we observe evidence for 

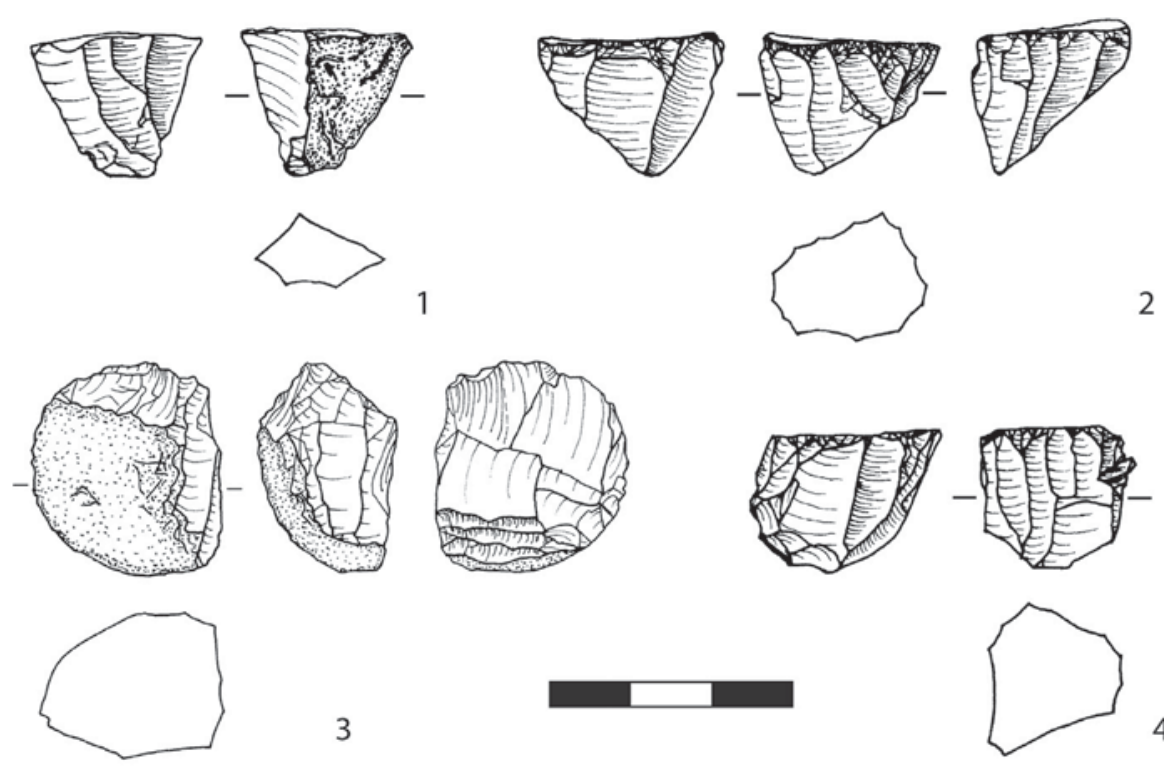

\section{3}
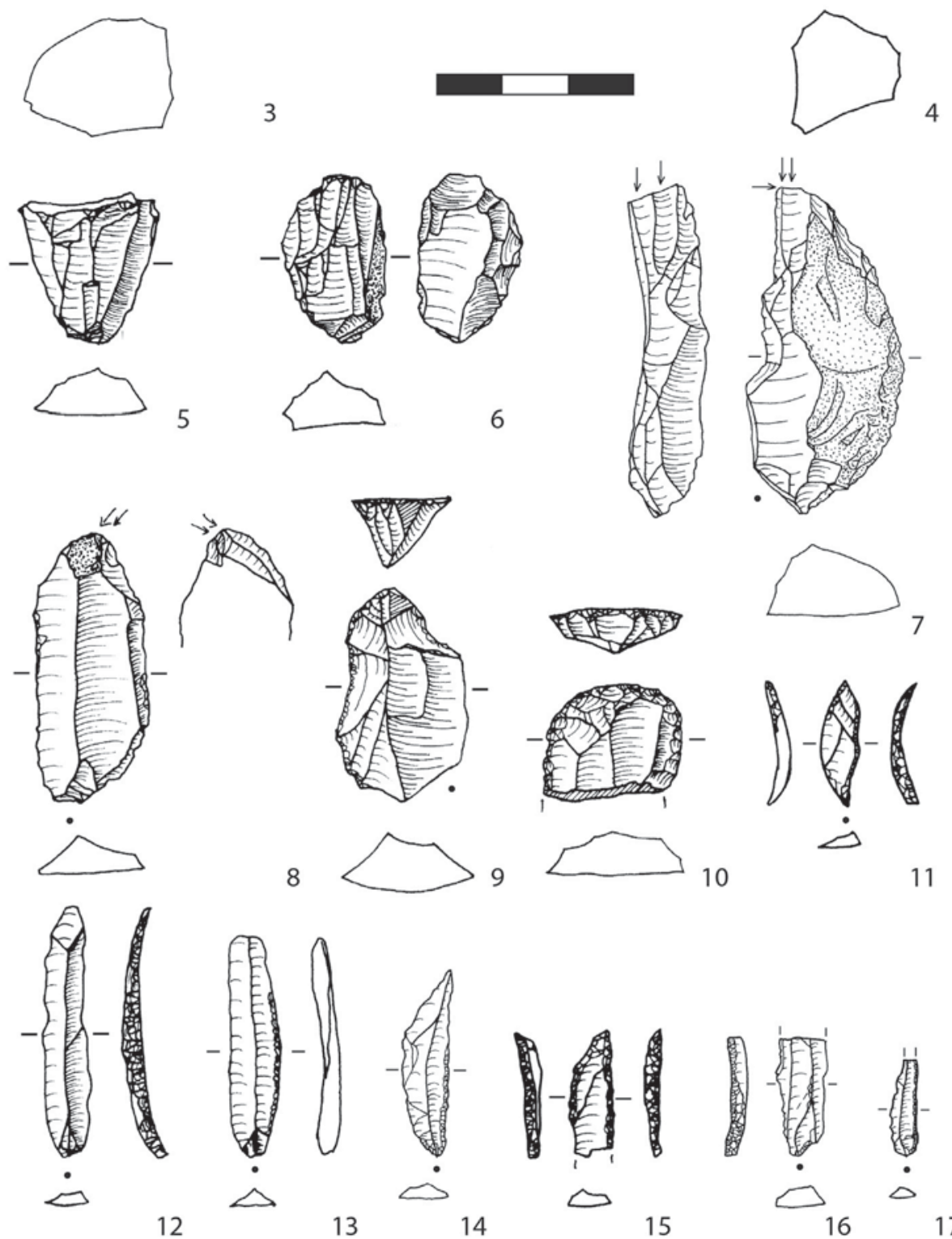

Figure 7. Selected artifacts from AH III, including unidirectional (1-5) and bidirectional cores (6), burins $(7,8)$, end scrapers (9, 10), backed point (11), backed bladelets $(12,15,16)$, and laterally retouched bladelets $(13,14,17)$. Scale is $3 \mathrm{~cm}$. Obsidian $(1-4,6-9,11-17$, chert $(5,10)$. (Illustration: E. Ghasidian). 

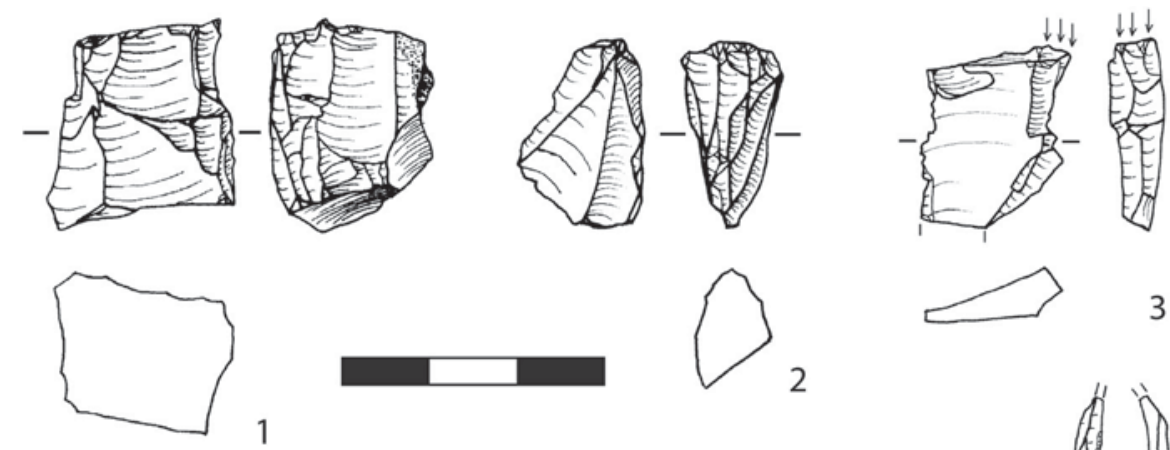

3
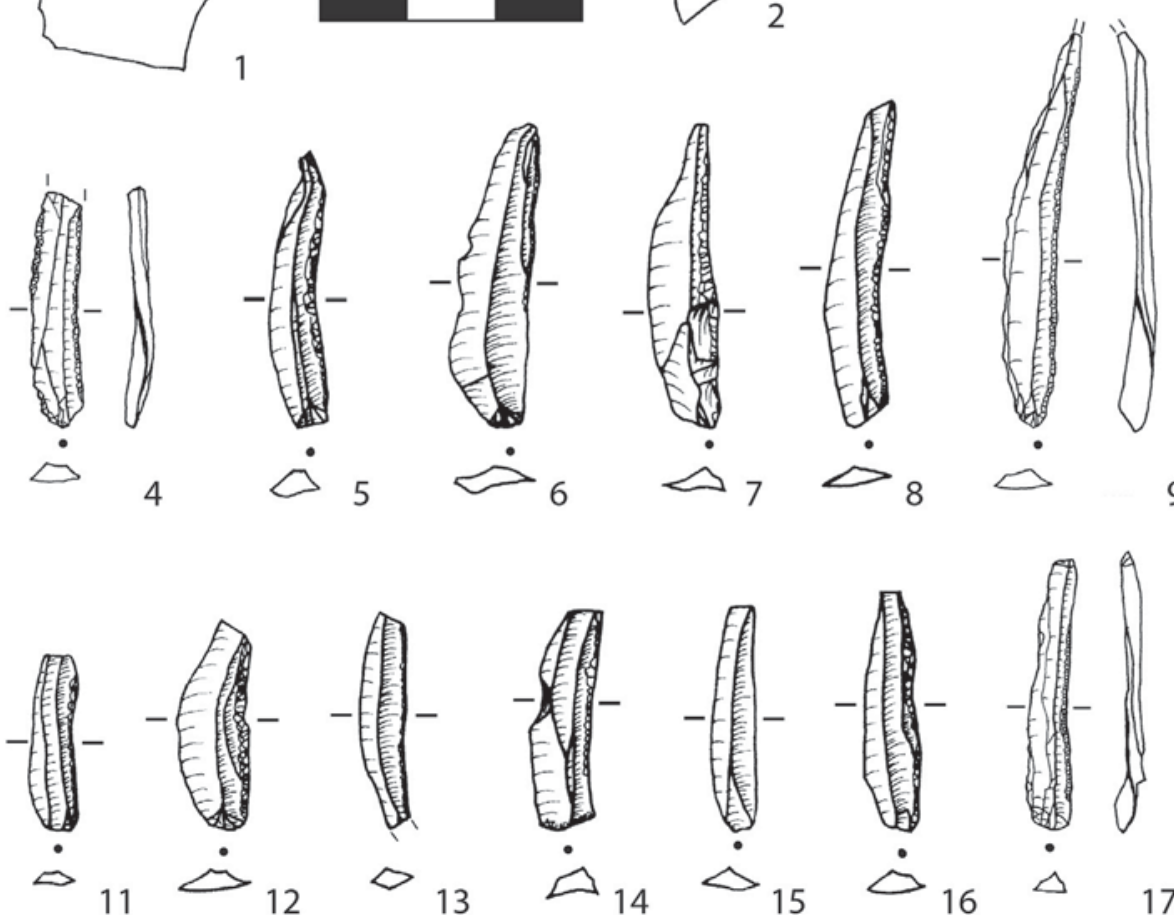

Figure 8. Selected artifacts from AH VI, including unidirectional cores (1-2), burin (3), laterally retouched bladelets (4-14, 16, 17), and an unretouched bladelet (15). Scale is 3 cm. Obsidian $(2-4,6,9-11,13,17)$, chert $(1,5,7,8,12,14-16)$. (Illustration: E. Ghasidian).

bidirectional knapping of blades along one removal surface. While no unidirectional cores were recorded, four bladelets attest to a mode of production more typical for AH VI and III. Thus we see evidence in AH VII for two production chains. AH VII is also unusual in that flakes and laminar blanks are present in equal proportions. As for the tools, five laterally retouched laminar blanks and five burins are present, while backed pieces are lacking. These results contrast with those of the overlying layers. The presence of a bidirectional knapping strategy, more flakes, and a greater focus on burin technology may suggest that the earliest phase of occupation at Aghitu-3 differs from those that followed.

\subsection{Obsidian sourcing and surveys}

We conducted field reconnaissance of the Syunik volcanic complexes to assess the availability of obsidian on the landscape. The volcanoes of Bazenk, Satanakar, and Sevkar are found $30-40 \mathrm{~km} \mathrm{NW}$ of Aghitu at altitudes of 2500-3000 m. Large blocks of obsidian are easy to find at the outcrops and on large scree deposits trailing down the slopes. Water-worn cobbles $(\sim 10-25 \mathrm{~cm})$ of obsidian litter the upper tributaries of the Vorotan near the sources. Our surveys also identified occasional water-worn pebbles $(\sim 3-5 \mathrm{~cm})$ of obsidian along the steep slopes of the Vorotan valley near Sisian and Aghitu.
To identify the preferred volcanic sources, we analyzed almost a quarter of the obsidian artifacts $(n=1121)$ using portable X-ray fluorescence (pXRF). XRF has frequently been used for obsidian artifact sourcing since the 1960s, and pXRF has become an established tool for such analyses in recent years (see Frahm and Feinberg, 2015 and references therein). Our initial artifact analyses in $2012(n=76)$ used a Thermo Scientific Niton XL2 500 instrument, while our subsequent analyses of artifacts in 2013 and 2015 ( $n=677$ and 368, respectively) and of geological source specimens used a Niton XL3t 950 GOLDD + instrument. Our procedures followed those detailed in Frahm (2014). Figure 10 illustrates matches between our artifacts and their source data, normalized to a particular element ( $\mathrm{Zr}$ or $\mathrm{Fe}$ ), as a means to minimize effects from variability due to artifact size and shape (Davis et al., 2011; Frahm, 2016). Our source attributions principally rely on the so-called "mid-Z" elements (e.g., $\mathrm{Nb}, \mathrm{Rb}, \mathrm{Sr}, \mathrm{Zr}$ ), which are well measured by XRF techniques even for irregular or curved artifacts (Davis et al., 2011; Forster et al., 2011). However, we used different elements ( $\mathrm{Fe}$ and $\mathrm{Mn}$ ) for our source assignments with the 2012 dataset because transparent fingernail polish applied to protect the artifacts' labels contained sufficient $\mathrm{Nb}$ and $\mathrm{Zr}$ to interfere with their reliable measurement. Only three artifacts from 2012 were not confidently matched to their sources, likely a result of interference from the fingernail polish. Fully calibrated elemental data and their ratios for these artifacts and their volcanic sources 

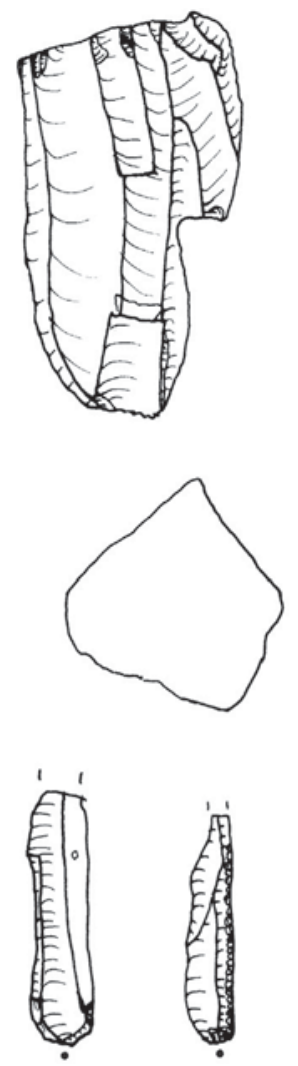

6

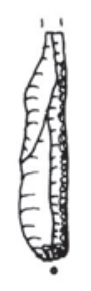

7
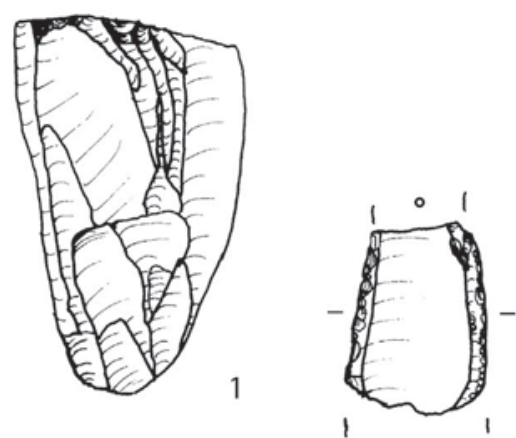

2
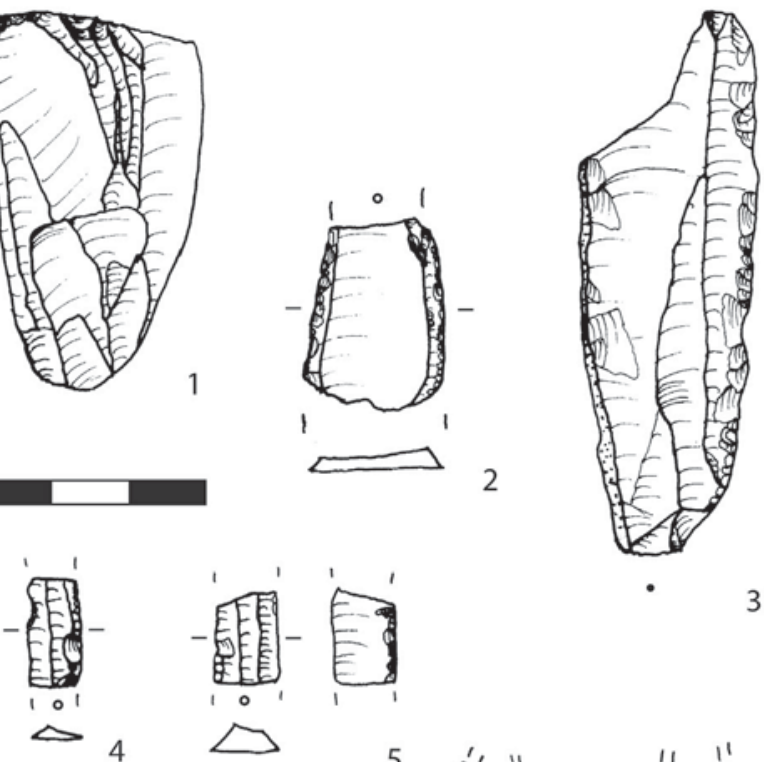

5
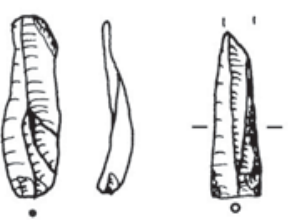

8

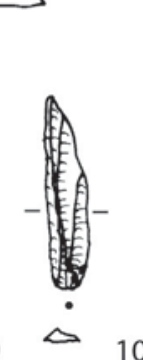

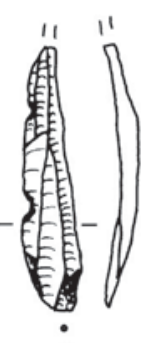

11
12

Figure 9. Selected artifacts from AH VII, including bidirectional core (1), laterally retouched blades (2, 3), laterally retouched bladelets (4, 5, 7, 9, 11), and unretouched bladelets (6, 8, $10,12)$. Scale is $3 \mathrm{~cm}$. Obsidian $(1-6,8-10,12)$, chert $(7,11)$. (Illustration: V. Vardazaryan).

Table 8

Statistical data for the lengths and widths of complete bladelets.

\begin{tabular}{lccc}
\hline Length & AH III & AH VI & AH VII \\
\hline Average & 25.7 & 29.6 & 33.1 \\
St. Dev. & 11.7 & 9.8 & 18.8 \\
Median & 23.8 & 29.4 & 27.0 \\
Count & 700 & 83 & 31 \\
\hline Width & AH III & AH VI & AH VII \\
\hline Average & 9.0 & 7.0 & 7.8 \\
St. Dev. & 4.4 & 2.9 & 4.7 \\
Median & 8.0 & 6.4 & 6.6 \\
Count & 700 & 83 & 31 \\
\hline
\end{tabular}

are presented in the Supplementary Online Material (SOM) Table S1.

Table 11 summarizes the source attributions of the 1121 artifacts, while Figure 11 shows the locations of these obsidian sources relative to Aghitu-3. In AH VII and VI, almost all of the artifacts (98-99\%) originate from two of the Syunik sources, Satanakar and Sevkar. However, three artifacts were attributed to distant sources-Geghasar 1, Gutansar, and Hatis-located 150-180 km NW. The low number of artifacts sampled from AH VII and VI reflects a decrease in artifact density with depth rather than sampling bias.

AH III accounts for three-quarters $(n=840)$ of the sourced artifacts and contains the greatest variety of obsidian from the most distant sources. While Syunik sources still dominate with 92\%, six additional Armenian obsidian sources were identified. These lie northwest of the cave in river basins not linked to the Vorotan, meaning only human transport can explain the occurrence of the materials at Aghitu-3. Five of the sources-Geghasar 1 and 2, Gutansar, Hatis, and Damlik (one of the Tsaghkunyats sources)-are located $\sim 110-180 \mathrm{~km}$ to the northwest. The sixth source-Pokr Arteni-is $\sim 220 \mathrm{~km}$ from Aghitu-3, but on foot, even the most direct path is $\sim 270 \mathrm{~km}$. The last and most distant obsidian source is Meydan Dağ in eastern Turkey, 250 km linearly. Until now, Meydan Dağ obsidian has only been documented in Armenia as an uncommon temper in Chalcolithic pottery at Aratashen (Palumbi et al., 2014).

We also considered which artifact types people brought to Aghitu-3 from which sources. In Table 6 we noted that tools represent $17 \%$ and cores $2 \%$ for all raw materials. In Table 12 we note similar proportions of tools $(15 \%)$ and cores $(1 \%)$ for the regionally sourced obsidian artifacts. This is not surprising because obsidian is the dominant raw material, and most of it originates from regional sources. We then examined only the distant artifacts, as we expected that far-traveled artifacts would include more tools and cores; however, we did not observe this effect among artifacts imported from distant sources. In Table 13 we see that tools (18\%) and cores $(3 \%)$ are present in ratios similar to the distributions mentioned above. Hence, we see no tendency toward the preference of distant obsidian sources for tools and cores.

In addition to artifact type, we examined the maximum dimension of artifacts brought to the site. The largest piece from the regional sources was $86 \mathrm{~mm}$, but the mean was $20.3 \pm 8.9 \mathrm{~mm}$. For the distant sources, the largest piece was $35 \mathrm{~mm}$; however, the mean was $17.5 \pm 6.1 \mathrm{~mm}$. Thus, the average sizes overlap within one standard deviation and are not significantly different.

We also examined what kinds of artifacts were manufactured from the distant sources. For example, laterally retouched bladelets 
Table 9

Distribution of tool types, separated into blank categories, showing percentage of each blank type compared to the total number of tools.

\begin{tabular}{|c|c|c|c|c|c|c|}
\hline Tool type & AH III & AH IV & $\mathrm{AH} \mathrm{V}$ & $\mathrm{AH} \mathrm{VI}$ & AH VII & TOTAL \\
\hline \multicolumn{7}{|l|}{ Bladelets } \\
\hline Lateral retouch & 228 & 1 & 4 & 62 & 4 & 299 \\
\hline Backed pieces & 144 & 1 & - & 4 & - & 149 \\
\hline End retouch & 9 & - & - & - & - & 9 \\
\hline Burins & 6 & - & - & - & 1 & 7 \\
\hline Drills & 2 & - & - & - & - & 2 \\
\hline Notches/denticulates & 2 & - & - & - & - & 2 \\
\hline Retouched pieces & 19 & - & - & 1 & - & 20 \\
\hline Sub-total bladelets & 410 & 2 & 4 & 67 & 5 & 488 \\
\hline \% Bladelets & $55 \%$ & $67 \%$ & $100 \%$ & $88 \%$ & $36 \%$ & $58 \%$ \\
\hline \multicolumn{7}{|l|}{ Blades } \\
\hline Lateral retouch & 30 & - & - & - & 1 & 31 \\
\hline Backed pieces & 3 & - & - & - & - & 3 \\
\hline End retouch & 5 & - & - & - & - & 5 \\
\hline Burins & 19 & - & - & - & 1 & 20 \\
\hline Drills & 3 & - & - & - & - & 3 \\
\hline Notches/denticulates & 7 & - & - & 1 & - & 8 \\
\hline Retouched pieces & 11 & 1 & - & - & - & 12 \\
\hline Sub-total blades & 78 & 1 & 0 & 1 & 2 & 82 \\
\hline \% Blades & $10 \%$ & $33 \%$ & $0 \%$ & $1 \%$ & $14 \%$ & $10 \%$ \\
\hline \multicolumn{7}{|l|}{ Flakes } \\
\hline Lateral retouch & 103 & - & - & 3 & 2 & 108 \\
\hline Backed pieces & 27 & - & - & 1 & - & 28 \\
\hline Side scrapers & 16 & - & - & & - & 16 \\
\hline End scrapers & 30 & - & - & 1 & - & 31 \\
\hline Burins & 20 & - & - & 1 & 3 & 24 \\
\hline Drills & 1 & - & - & - & 1 & 2 \\
\hline Notches/denticulates & 13 & - & - & - & - & 13 \\
\hline Splintered pieces & 7 & - & - & 1 & - & 8 \\
\hline Retouched pieces & 40 & - & - & 1 & 1 & 42 \\
\hline Sub-total flakes & 257 & 0 & 0 & 8 & 7 & 272 \\
\hline \% Flakes & $34 \%$ & $0 \%$ & $0 \%$ & $11 \%$ & $50 \%$ & $32 \%$ \\
\hline TOTAL & 745 & 3 & 4 & 76 & 14 & 842 \\
\hline
\end{tabular}

Table 10

Distribution of core types. See text for further descriptions.

\begin{tabular}{lcccccc}
\hline Core type & AH III & AH IV & AH V & AH VI & AH VII & TOTAL \\
\hline Unidirectional & 66 & - & - & 2 & - & 68 \\
Bidirectional & 19 & - & - & - & 2 & 21 \\
Multidirectional & 6 & - & - & - & - & 6 \\
Radial & 1 & - & - & - & - & 1 \\
Cores on flakes & 5 & - & - & 1 & 2 & 8 \\
Initial & 6 & - & - & - & - & 6 \\
Indeterminate core fragments & 7 & - & - & - & - & 7 \\
TOTAL & 110 & 0 & 0 & 3 & 4 & 117 \\
\hline
\end{tabular}

and backed bladelets are among the distant pieces from AH III, as are two small bidirectional cores. But so too are a splintered piece and a core tablet, as well as debitage. In other words, we do not observe a relationship between the source-to-site distances and either artifact type, size, or even the pieces themselves. Further work will be needed to assess if the obsidian arrived at Aghitu-3 more often as ready-made tools, pre-shaped blanks, or unworked cobbles. Additional source testing will also be needed to expand the sample sizes.

Keeping in mind the difference in assemblage size, we conclude that distant sources of obsidian are rare in AH VII and VI and occur more frequently in AH III. The increase in distant sources from $1 \%$ in AH VII and VI to $8 \%$ in AH III is statistically significant (Fisher's exact test, AH III vs. VII: $p<0.01$; AH III vs. VI: $p<0.01$ ). These results provide clear evidence that UP people transported obsidian over long distances and that this phenomenon increased over the course of the UP. At present, we cannot specify whether the obsidian entered the site as a result of direct procurement via mobility and/ or exchange through long-distance social networks. Nor can we assert in what form the obsidian arrived on-site. Nonetheless, pXRF analyses reveal the movement of obsidian in multiple directions from many sources. Future studies will include additional surveying and geo-referenced sampling of the Syunik obsidian sources to interpret our artifact data more precisely. This will allow us to understand the compositional variability of the Syunik obsidians and their expression across the landscape. Our goal is to interpret the data in terms of mobility and use of the landscape at these times and to understand how UP populations optimized their use of the environment.

\subsection{Large mammalian remains}

We analyzed the large mammalian remains $(n=2291)$, calculating the number of identified specimens (NISP) and the minimum number of individuals ( $\mathrm{MNI}$ ) based on the most frequent elements, taking into account side and age. Overall we identified 65\% $(\mathrm{NISP}=1499)$ of the finds to at least the level of genus (Table 14). Most of the fauna comes from AH III (76\%, NISP = 1749), followed by AH VI $(17 \%$, NISP $=398)$. We categorized the remaining specimens into four size classes based on live weight following Brain (1974) and Klein et al. (1991). The smallest and least common size class $1(5-20 \mathrm{~kg}$ ) is represented mainly by hare (Lepus capensis), followed by the dominant size class $2(20-100 \mathrm{~kg})$ which includes wild sheep (Ovis sp.) and wild goat (Capra sp.). Size class 3 $(100-300 \mathrm{~kg})$ consists mainly of equids (Equus sp.) and a few cervids (Cervus elaphus), while the largest size class 4 (300-1000 kg) includes bovids (Bos/Bison). Microvertebrate remains including micromammals are tallied separately and discussed later.

Comparing the two layers with the most fauna, we see that the share of the dominant genera, Ovis and Capra combined, varies from $83 \%(\mathrm{NISP}=195, \mathrm{MNI}=10)$ in $\mathrm{AH}$ VI, to $54 \%(\mathrm{NISP}=628$, $\mathrm{MNI}=6)$ in $\mathrm{AH}$ III. Conversely equids in $\mathrm{AH}$ VI account for $6 \%$ $(\mathrm{NISP}=13, \mathrm{MNI}=1)$ compared to $37 \%(\mathrm{NISP}=427, \mathrm{MNI}=3)$ in $\mathrm{AH}$ III. Together these taxa represent about $90 \%$ of the fauna in each layer. The distribution of fauna identified to size classes 2 and 3 mirrors the dominance of these mid-sized animals. One interesting note is that the high NISP observed in AH III does not translate into greater MNI. This likely results from the high degree of fragmentation, especially in AH III, which hinders the identifiability of the faunal remains. AH III yielded the highest NISP and shows a greater diversity of species, followed by AH VI. Carnivores, including wolf and fox, comprise just $1 \%$ of the entire assemblage, while hares are present overall at $3 \%$.

The general and surface preservation of fauna in AH III ranges from good to excellent, and the bones are on average well mineralized. We observed anthropogenic modifications such as cut marks, spiral breaks, and burning on 132 bones, while 24 show evidence of modification by carnivores (Table 15). However, the bones in AH VI are generally not as well preserved, and are less mineralized. In AH VI, anthropogenic modifications were observed on only one bone, with three modified by carnivores (Table 15). No modifications were observed on the bones from AH VII. Of the $7 \%$ of bones from AH III that show signs of modification, about half are related to burning. Anthropogenic modifications in AH III clearly outnumber those related to carnivore activity. Several factors further support humans as the primary accumulators of the AH III assemblage, including the direct association of diverse, mediumsized game with lithic and organic artifacts, plentiful combustion features, the rare presence of carnivore remains, and the lack of coprolites. While these factors also apply to AH VI and VII, the assemblages are much smaller, and the taphonomic observations far fewer. Thus, the connection between the lithics and fauna in AH VI and VII is less clear, and these accumulations of fauna cannot be conclusively tied to human activity. 

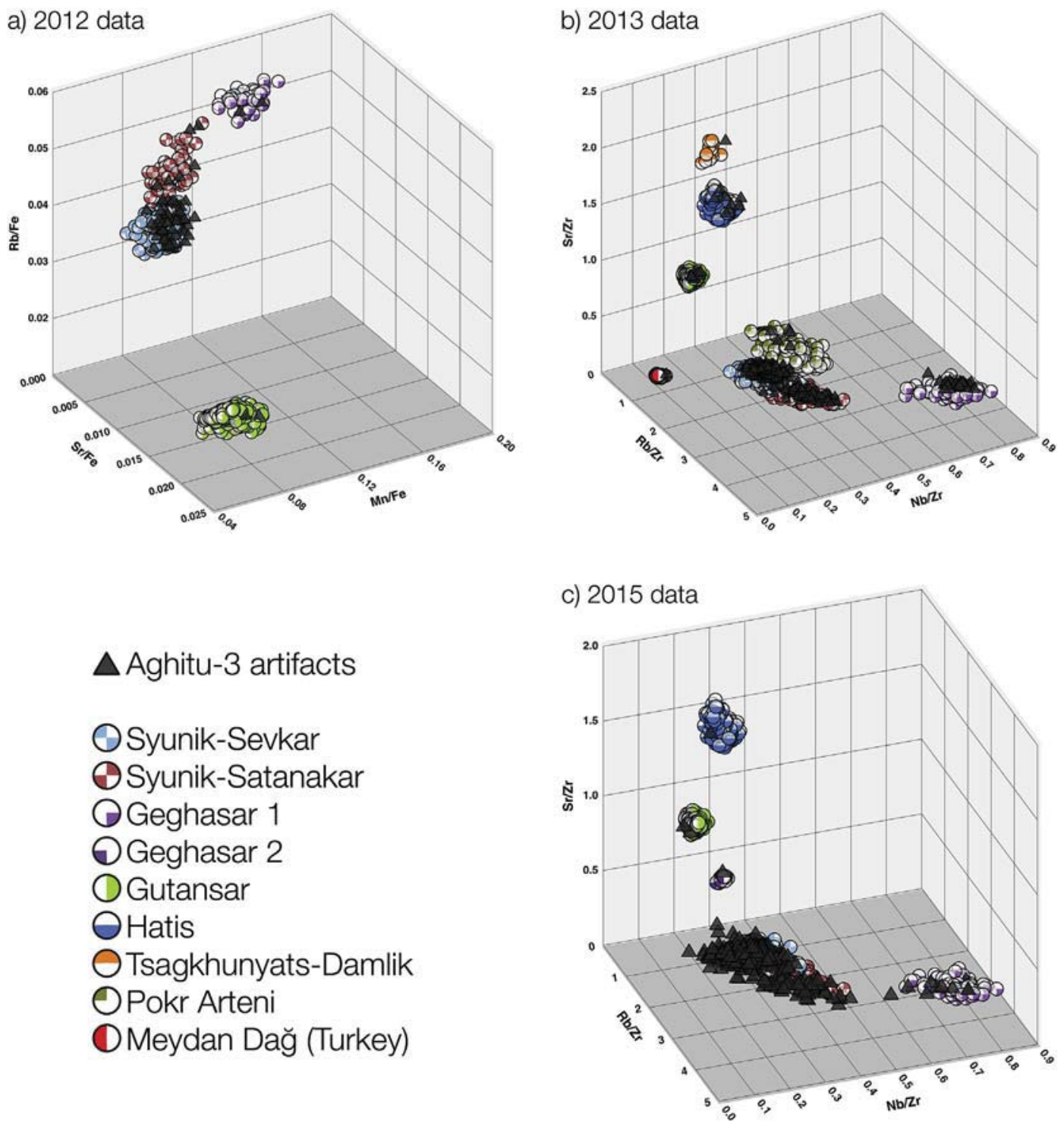

Figure 10. Scatterplots showing concentrations for obsidian artifacts from Aghitu-3 and their corresponding sources: a) Rb/Fe, $\mathrm{Sr} / \mathrm{Fe}$, and $\mathrm{Mn} / \mathrm{Fe}$ from the 2012 exploratory analyses $(n=80) ; \mathrm{b}-\mathrm{c}) \mathrm{Rb} / \mathrm{Zr}, \mathrm{Sr} / \mathrm{Zr}$, and Nb/Zr from the $2013(n=677)$ and $2015(n=383)$ analyses. Ratioing concentrations to a particular element (e.g., Fe, Zr) is an established approach to minimize variability due to artifact size and shape.

\subsection{Organic artifacts}

Rare bone tools and shell beads count among the archaeological remains recovered from AH III. Three bone tools were discovered in the lower part of $\mathrm{AH}$ III. The first is a fragment of a thin glossy needle with a broken eye and a blunt tip from AH IIId (Fig. 12a). The second is a very sharp, highly polished, complete bone point from AH IIIc (Fig. 12b), and the third is a polished awl from AH IIId with both ends incomplete (Fig. 12c). While all three tools are made from long bones, they are highly modified and preclude identification to taxa.

Furthermore, eight perforated shells about $6 \mathrm{~mm}$ long and $5 \mathrm{~mm}$ wide (Fig. 13) were recovered during the screening of AH III: three from AH IIIa; two from AH IIIc; and three from AH IIId. The perforations vary in size, but are similarly located on the body whorl behind the aperture. Two shells show traces of ocher and one of these shows longitudinal striations near the aperture, suggesting this bead was strung. Using the collection of the Zoological Institute of the Armenian National Academy of Sciences, we identified the shells as Theodoxus pallasi. This neritid gastropod is widely distributed in brackish waters of the Caspian Sea region but may also live in inland lakes and rivers (Akramovski, 1976). Most importantly, the shell beads reveal an eastward connection, complementing our findings regarding obsidian transport from the northwest and southwest.

\section{Microvertebrate remains}

\subsection{Micromammals}

We analyzed variation in the micromammalian assemblage by examining changes in taxonomic and taphonomic patterns along the stratigraphic profile. Taxonomic composition was determined using comparative collections of the Naturhistorisches Museum Wien and the Zoological Institute of the Armenian National Academy of Sciences. Where possible, taxonomic designations at the species level are based on modern distributions retrieved from online databases of the IUCN Red List (2015) and WWF Wild Finder 
Table 11

Number and proportion of obsidian artifacts sampled from each obsidian source.

\begin{tabular}{|c|c|c|c|c|c|c|c|c|c|c|c|c|}
\hline \multirow[t]{2}{*}{ Obsidian source/Volcanic complex } & \multicolumn{2}{|c|}{ AH III } & \multicolumn{2}{|c|}{ AH IV } & \multicolumn{2}{|c|}{$\mathrm{AH} \mathrm{V}$} & \multicolumn{2}{|c|}{ AH VI } & \multicolumn{2}{|c|}{ AH VII } & \multicolumn{2}{|c|}{ TOTAL } \\
\hline & $n$ & $\%$ & $n$ & $\%$ & $n$ & $\%$ & $n$ & $\%$ & $n$ & $\%$ & $n$ & $\%$ \\
\hline \multicolumn{13}{|l|}{ Regional $(<50 \mathrm{~km})$} \\
\hline Syunik-Sevkar & 579 & $69 \%$ & 5 & $100 \%$ & 10 & $100 \%$ & 150 & $90 \%$ & 74 & $75 \%$ & 818 & $73 \%$ \\
\hline Syunik-Satanakar & 169 & $20 \%$ & - & - & - & - & 10 & $6 \%$ & 23 & $23 \%$ & 202 & $18 \%$ \\
\hline Syunik-undifferentiated & 23 & $3 \%$ & - & - & - & - & 4 & $2 \%$ & 1 & $1 \%$ & 28 & $2 \%$ \\
\hline Total Regional & 771 & $92 \%$ & 5 & $100 \%$ & 10 & $100 \%$ & 164 & $98 \%$ & 98 & $99 \%$ & 1048 & $93 \%$ \\
\hline \multicolumn{13}{|l|}{ Distant $(100-200 \mathrm{~km})$} \\
\hline Geghasar 1 & 39 & $4.6 \%$ & - & - & - & - & 1 & $0.6 \%$ & - & - & 40 & $3.6 \%$ \\
\hline Geghasar 2 & 1 & $0.1 \%$ & - & - & - & - & - & - & - & - & 1 & $0.1 \%$ \\
\hline Gutansar & 12 & $1.4 \%$ & - & - & - & - & - & - & 1 & $1 \%$ & 13 & $1.2 \%$ \\
\hline Hatis & 8 & $1 \%$ & - & - & - & - & 1 & $0.6 \%$ & - & - & 9 & $0.8 \%$ \\
\hline Tsaghkunyats-Damlik & 1 & $0.1 \%$ & - & - & - & - & - & - & - & - & 1 & $0.1 \%$ \\
\hline Total Distant & 61 & $7.3 \%$ & - & - & - & - & 2 & $1.2 \%$ & 1 & $1 \%$ & 64 & $5.7 \%$ \\
\hline \multicolumn{13}{|l|}{ Long-distance $(>200 \mathrm{~km})$} \\
\hline Pokr Arteni & 5 & $0.6 \%$ & - & - & - & - & - & - & - & - & 5 & $0.4 \%$ \\
\hline Meydan Dağ (Turkey) & 1 & $0.1 \%$ & - & - & - & - & - & - & - & - & 1 & $0.1 \%$ \\
\hline Total Long-distance & 6 & $0.7 \%$ & - & - & - & - & - & - & - & - & 6 & $0.5 \%$ \\
\hline Sources unidentified & 2 & $0.2 \%$ & - & - & - & - & 1 & $0.6 \%$ & - & - & 3 & $0.3 \%$ \\
\hline TOTAL & 840 & $75 \%$ & 5 & $0.4 \%$ & 10 & $1 \%$ & 167 & $15 \%$ & 99 & $9 \%$ & 1121 & $100 \%$ \\
\hline
\end{tabular}

(2006). Issues related to assemblage formation and preservation were assessed by reference to the composition and completeness of skeletal elements and evidence for predator digestion.

For this analysis, we screened about $13 \mathrm{~m}^{3}$ of sediment using a $1 \mathrm{~mm}$ mesh from a vertical column spanning the entire profile. The sample yielded 2543 cranial and post-cranial specimens of micromammals from AH VII-III, mainly members of the orders Rodentia and Lagomorpha, and a single find of Eulipotyphla. We subdivided AH III into an upper (AH IIIa-b) and lower (AH IIIc-d) portion. The overall assemblage demonstrates an exceptionally good state of preservation, a moderate abundance of remains, and a moderate level of taxonomic diversity. The abundance varies considerably along the stratigraphic sequence.

The taxonomic analysis of the assemblage is based on the NISP and MNI obtained from $578 \mathrm{M}$ teeth (Table 16). Of the 10 taxa identified in the assemblage, the three most abundant occur throughout the stratigraphic sequence. These include two rodents, the field vole (Microtus spp.) and Brandt's hamster (Mesocricetus brandti), and one lagomorph, the Afghan pika (Ochotona rufescens). While the patchy occurrence of rarer taxa along the stratigraphic sequence may be an artifact of sampling, the Transcaucasian mole vole (Ellobius lutescens) is present in only $\mathrm{AH}$ VII. Because southern Armenia now forms the northern edge of this species' range, its presence indicates climatic conditions at the base of the sequence that were similar to those at present. Nine of the 10 taxa present have modern distributions which encompass the Aghitu area. The one exception is the Afghan pika, which currently shows a highly fragmented distribution south of Armenia, present in parts of eastern Turkey and Iran (Čermák et al., 2006). Its retreat and range fragmentation may have resulted from Holocene warming as documented in the North American pika (Galbreath et al., 2009).

To assess vertical changes in taxonomic abundances, we standardized NISP data to the different thicknesses of the stratigraphic units by computing relative abundance of taxa and their percentage occurrence in each unit. Percentage occurrence for each taxon in each of the excavation units was obtained by dividing the number of excavation spits containing that taxon by the total number of spits for each unit. The results of a principal component (PC) analysis are shown in two scatterplots (Fig. 14). For percentage occurrence data, PC1 (87.15\% of variation) separates AH V and IV, which show a high percentage, from all other stratigraphic units
(Fig. 14a). In AH V and IV, high rates of deposition of micromammal remains are associated with a reduced presence of humans in the cave. Lower rates of micromammal accumulation are seen in AH VI and especially $\mathrm{AH}$ III, both of which correspond to times when human use of the cave increased. In a second scatterplot for the relative abundance data, PC3 (5.24\%) separates AH VII and VI, which show relatively high frequencies of the Brandt's hamster, from other units where the Afghan pika tends to be more abundant (Fig. 14b).

Moving up the sequence at Aghitu-3, we see a gradual cooling trend as indicated by an increase in the Afghan pika and a corresponding decrease in Brandt's hamsters. The presence of the Transcaucasian mole vole within only AH VII indicates nearmodern climatic conditions at that time. This species was documented in UP and Holocene deposits of Hovk Cave but was absent in its earlier Late Pleistocene layers (Pinhasi et al., 2011). In the lowland Imereti region of Georgia, this species was associated mainly with layers dated to $\sim 24-22,000$ cal BP and showed reduced frequencies in layers dated to $\sim 17-16,000$ cal BP (Pinhasi et al., 2014). The mean combined frequency of all species of voles (Microtus spp., Chionomys sp., Arvicola amphibious and E. lutescens) among the layers of Aghitu-3 is $61.9 \pm 12.1 \%$, which fits with our assessment of a colder climate and higher altitude. In a series of recent micromammalian assemblages from Armenia ( $n=7$; described in Vereshchagin, 1967) vole frequencies $>50 \%$ occur at altitudes above $2000 \mathrm{~m}$, but drop below 40\% at lower altitudes.

Taphonomic indices suggest a consistency in the mechanism of accumulation active in the cave throughout the sequence (Table 17). Numbers of specimens showing signs of digestion remains low in all units. Variation in skeletal element representation along the sequence is likely due to post-depositional fragmentation, which appears to be low in AH V and IV but more evident in AH VII, VI, and III. A scatterplot (Fig. 15) depicts skeletal element composition based on the calculation of minimum number of elements (MNE) (Table 17). PC1 (83.72\%) separates these two groups of units. Along PC2 (7.54\%), fragile cranial, pelvic, and pectoral elements are more abundant in lower AH III than in upper AH III, whereas all other units occupy an intermediate position. An index of skeletal element completeness shows that AH V and IV contain a relatively high proportion of intact cranial elements, especially mandibles: $60-70 \%$ of complete elements in AH V and IV compared 


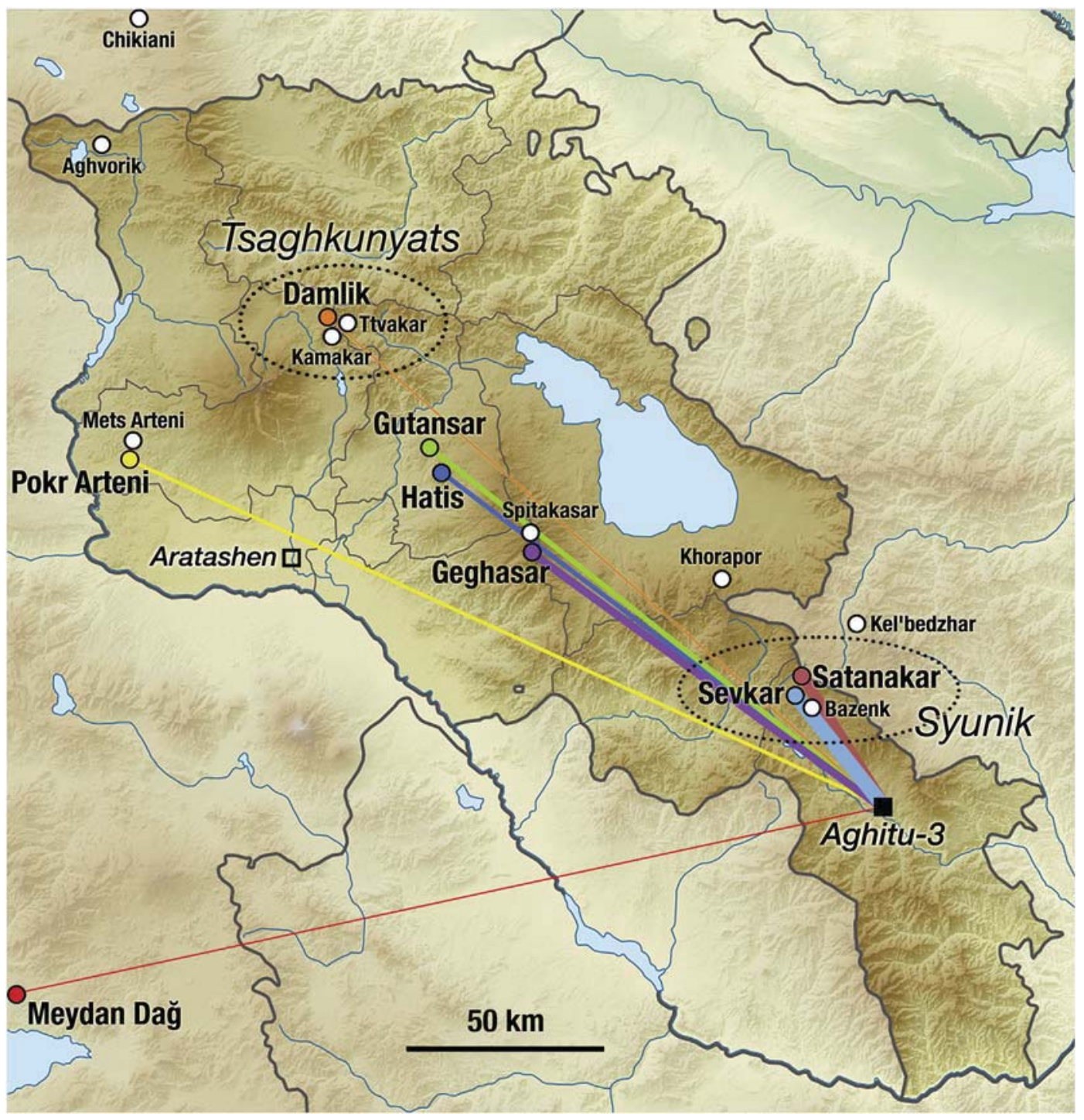

Figure 11. Map showing locations of obsidian sources in the Armenian Highlands relative to Aghitu-3. Colored circles with larger labels are sources identified among the Aghitu-3 obsidian artifacts. White circles with smaller labels are sources that are not represented. The thicknesses of the lines between the sources and Aghitu are proportional (log scale) to their abundance in the cave. These lines are symbolic and intended as neither literal paths nor indicators of direct procurement excursions. Obsidian localities with different names but indistinguishable chemical compositions are represented by a single circle, and no effort is made here to represent the entire primary and secondary distributions of the obsidians. An open square denotes an archaeological site discussed in the text. Digital elevation data from SRTM3. (For interpretation of the references to colour in this figure legend, the reader is referred to the web versionof this article).

Table 12

Breakdown of sourced obsidian artifacts by lithic category.

\begin{tabular}{|c|c|c|c|c|c|c|c|c|c|c|c|c|}
\hline \multirow{2}{*}{$\begin{array}{l}\text { Lithic category } \\
\text { Blanks }\end{array}$} & \multicolumn{2}{|c|}{ AH III } & \multicolumn{2}{|c|}{ AH IV } & \multicolumn{2}{|c|}{$\mathrm{AH} \mathrm{V}$} & \multicolumn{2}{|c|}{ AH VI } & \multicolumn{2}{|c|}{ AH VII } & \multicolumn{2}{|c|}{ TOTAL } \\
\hline & 666 & $79 \%$ & 5 & $100 \%$ & 10 & $100 \%$ & 151 & $90 \%$ & 96 & $97 \%$ & 928 & $83 \%$ \\
\hline Tools & 158 & $19 \%$ & - & - & - & - & 11 & $7 \%$ & 3 & $3 \%$ & 172 & $15 \%$ \\
\hline Cores & 13 & $2 \%$ & - & - & - & - & - & - & - & - & 13 & $1 \%$ \\
\hline Angular debris & 3 & $0.4 \%$ & - & - & - & - & 5 & $3 \%$ & - & - & 8 & $1 \%$ \\
\hline TOTAL & 840 & $100 \%$ & 5 & $100 \%$ & 10 & $100 \%$ & 167 & $100 \%$ & 99 & $100 \%$ & 1121 & $100 \%$ \\
\hline
\end{tabular}

to $<30 \%$ in all other units (Table 18 ). Less variation is observed in frequencies of fragmented specimens of the cranial and major limb elements.

\subsection{Fish, amphibians, and reptiles}

Ectothermic vertebrate fauna were recovered from the screened sediments of Aghitu-3 and derive from two layers, the lag deposit at the base of AH VII and III (Table 19). It is interesting to note the lack of fish, amphibians, and reptiles in the other horizons. In AH VII and III, vertebrae of trout (Salmo sp.) are most abundant, though one mandible was also identified. The vertebrae are identified as a riverine form of the brown trout, a species widely distributed in the streams and rivers of this mountainous region. The closest source of the trout would be the Vorotan River.

Based on the size of the vertebrae, we estimate an average body length of about $30 \mathrm{~cm}$, although some individuals in AH III range up to $40 \mathrm{~cm}$ long. While the sample is small, we note larger-bodied fish 
Table 13

Breakdown of distant obsidian artifacts from AH III by lithic category.

\begin{tabular}{|c|c|c|c|c|c|c|c|c|c|c|c|c|c|c|}
\hline \multirow{3}{*}{$\begin{array}{l}\frac{\text { Obsidian source }}{\text { AH III }} \\
\text { Blanks }\end{array}$} & \multicolumn{8}{|c|}{ Distant } & \multicolumn{4}{|c|}{ Long distance } & \multicolumn{2}{|c|}{ TOTAL } \\
\hline & \multicolumn{2}{|c|}{ Geghasar } & \multicolumn{2}{|c|}{ Gutanasar } & \multicolumn{2}{|c|}{ Hatis } & \multicolumn{2}{|c|}{ T-Damlik } & \multicolumn{2}{|c|}{ Meydan Dag } & \multicolumn{2}{|c|}{ Pokr Arteni } & \multirow[b]{2}{*}{54} & \multirow[b]{2}{*}{$79 \%$} \\
\hline & 35 & $85 \%$ & 8 & $67 \%$ & 6 & $75 \%$ & - & - & 1 & $100 \%$ & 4 & $80 \%$ & & \\
\hline Tools & 4 & $10 \%$ & 4 & $33 \%$ & 2 & $25 \%$ & 1 & $100 \%$ & - & - & 1 & $20 \%$ & 12 & $18 \%$ \\
\hline Cores & 2 & $5 \%$ & - & - & - & - & - & - & - & - & - & - & 2 & $3 \%$ \\
\hline Angular debris & - & - & - & - & - & - & - & - & - & - & - & - & - & - \\
\hline TOTAL & 41 & $100 \%$ & 12 & $100 \%$ & 8 & $100 \%$ & 1 & $100 \%$ & 1 & $100 \%$ & 5 & $100 \%$ & 68 & $100 \%$ \\
\hline
\end{tabular}

Table 14

NISP showing proportion of fauna and MNI. Taxa identified to genus and/or species are listed first, followed by general size class groups. See text for further descriptions.

\begin{tabular}{|c|c|c|c|c|c|c|c|c|c|c|c|c|c|c|c|c|c|}
\hline \multirow[t]{2}{*}{ Identified taxa } & \multicolumn{3}{|c|}{ AH III } & \multicolumn{3}{|c|}{ AH IV } & \multicolumn{3}{|c|}{$\mathrm{AH} \mathrm{V}$} & \multicolumn{3}{|c|}{ AH VI } & \multicolumn{3}{|c|}{ AH VII } & \multicolumn{2}{|c|}{ TOTAL } \\
\hline & $n$ & $\%$ & MNI & $n$ & $\%$ & MNI & $n$ & $\%$ & $\overline{\mathrm{MNI}}$ & $n$ & $\%$ & MNI & $n$ & $\%$ & MNI & $n$ & $\%$ \\
\hline Vulpes vulpes & 1 & $0.1 \%$ & 1 & - & - & - & - & - & - & - & - & - & 1 & $1 \%$ & 1 & 2 & $0.1 \%$ \\
\hline Canis lupus & 2 & $0.2 \%$ & 1 & 2 & $13 \%$ & 2 & 2 & $29 \%$ & 2 & 7 & $3 \%$ & 2 & 2 & $2 \%$ & 1 & 15 & $1 \%$ \\
\hline Lepus capensis & 19 & $2 \%$ & 2 & 4 & $25 \%$ & 1 & - & - & & 16 & $7 \%$ & 2 & 5 & $6 \%$ & 1 & 44 & $3 \%$ \\
\hline Equus sp. & 427 & $37 \%$ & 3 & 3 & $19 \%$ & 1 & - & - & & 13 & $6 \%$ & 1 & 18 & $22 \%$ & 1 & 461 & $31 \%$ \\
\hline Sus scrofa & 1 & $0.1 \%$ & 1 & - & - & - & - & - & - & - & - & - & - & - & - & 1 & $0.1 \%$ \\
\hline Cervus elaphus & 14 & $1 \%$ & 2 & - & - & - & - & - & - & 1 & $0.4 \%$ & 1 & - & - & - & 15 & $1 \%$ \\
\hline Ovis sp. & 82 & $7 \%$ & 2 & 1 & $6 \%$ & 1 & 1 & $14 \%$ & 1 & 41 & $17 \%$ & 4 & 20 & $25 \%$ & 2 & 145 & $10 \%$ \\
\hline Capra sp. & 9 & $1 \%$ & 1 & 1 & $6 \%$ & 1 & - & - & - & 9 & $4 \%$ & 3 & - & - & - & 19 & $1 \%$ \\
\hline Ovis/Capra & 537 & $46 \%$ & 3 & 5 & $31 \%$ & 2 & 3 & $43 \%$ & 1 & 145 & $62 \%$ & 3 & 35 & $43 \%$ & 2 & 725 & $48 \%$ \\
\hline Bos/Bison & 68 & $6 \%$ & 1 & - & - & - & 1 & $14 \%$ & 1 & 3 & $1 \%$ & 1 & - & - & - & 72 & $5 \%$ \\
\hline Subtotal identified & 1160 & $100 \%$ & & 16 & $100 \%$ & & 7 & $100 \%$ & & 235 & $100 \%$ & & 81 & $100 \%$ & & 1499 & $100 \%$ \\
\hline Small mammals (sc1) & 15 & $3 \%$ & & 1 & $9 \%$ & & 1 & $13 \%$ & & 28 & $17 \%$ & & - & - & & 45 & $6 \%$ \\
\hline Small medium mammals (sc2) & 272 & $46 \%$ & & 6 & $55 \%$ & & 4 & $50 \%$ & & 101 & $62 \%$ & & 10 & $48 \%$ & & 393 & $50 \%$ \\
\hline Large medium mammals (sc3) & 178 & $30 \%$ & & 4 & $36 \%$ & & 3 & $38 \%$ & & 26 & $16 \%$ & & 5 & $24 \%$ & & 216 & $27 \%$ \\
\hline Large mammals (sc4) & 117 & $20 \%$ & & - & - & & - & - & & 7 & $4 \%$ & & 5 & $24 \%$ & & 129 & $16 \%$ \\
\hline Indeterminate & 7 & $1 \%$ & & - & - & & - & - & & 1 & $1 \%$ & & 1 & $5 \%$ & & 9 & $1 \%$ \\
\hline Subtotal size classes & 589 & $100 \%$ & & 11 & $100 \%$ & & 8 & $100 \%$ & & 163 & $100 \%$ & & 21 & $100 \%$ & & 792 & $100 \%$ \\
\hline TOTAL Macrofauna & 1749 & - & & 27 & - & & 15 & - & & 398 & - & & 102 & - & & 2291 & - \\
\hline
\end{tabular}

Table 15

Summary of modifications to the faunal assemblage.

\begin{tabular}{lcc}
\hline Bone modification & AH III & AH VI \\
\hline Cut marks & 32 & - \\
Possibly worked & 2 & - \\
Spiral breaks & 25 & - \\
Burned & 73 & 1 \\
TOTAL (anthropogenically modified) & 132 & 1 \\
Bite or chew & 24 & 3 \\
TOTAL (all modified) & 156 & 4 \\
\hline
\end{tabular}

during the more intensive occupation in AH III, which might result from people selecting larger fish. Most of the fish vertebrae show good preservation and no traces of cutting or burning. The basal horizon of AH VII contains the remains of ectothermic animals, especially Salmo sp., a few bones of amphibians and reptiles, and large numbers of micromammals and birds. The base of AH VII is a natural deposit not associated with human activity and possibly accumulated by other predators. It contrasts with the clear anthropogenic nature of AH III. The herpetofaunal assemblages of AH VII and III includes taxa that inhabit open and dry areas, mountainous steppe and rocky areas, all of which can be found near Aghitu today.

\subsection{Avian fauna}

Most of the avian fauna was recovered during the picking of the fine sediments. While birds are present in all layers, the majority come from AH VII and VI. Of the 261 bird bones examined, 185 were identified at least to their taxonomic order (Table 20). All layers show a predominance of small and medium-sized perching birds
(Passeriformes), but due to the inherent difficulty in identifying this group, only nine specimens could be attributed to specific genera (Hirundinidae, cf. Fringilidae, Alaudidae, cf. Alaudidae, Alauda cf. arvensis, Corvus corax). The remaining bird bones belong to the orders Galliformes, Anseriformes, Charadriiformes, Apodiformes, Gruiformes, and Falconiformes. So far, we see no evidence that human modification of the bird bones occurred.

Although Laroulandie (2000) urges caution when comparing the relative abundance of avian skeletal elements, such data still provide a clue about the taphonomic agents involved in the accumulation of the assemblages (Mourer-Chauviré, 1983; Ericson, 1987). For example, an analysis of the 'wing-to-leg' ratio of Passeriformes indicates a predominance of wing bones in AH VII (74\%), VI (61\%) and III (61\%) (Fig. 16). Elements of the axial skeleton, cranium and shoulder girdle are underrepresented in all layers. Ericson (1987) and Laroulandie (2002) note such a pattern of predominantly unfragmented wing bones in their taphonomic studies of the prey remains of certain birds of prey.

Since we found no evidence for anthropogenic accumulation of the bird bones, a scenario of predator accumulation seems most likely. This would explain the presence of such families of birds as Anatidae, Phasianidae and Charadriidae/Scolopacidae, which are not generally associated with caves. They are, however, common prey of large raptors and owls. On the other hand, the remains of common swift (Apus apus) and swallow (Hirundinidae) are more likely related to birds that nested within protected areas of the cave walls.

All bird species identified in Aghitu-3 are present in Armenia today (Adamian and Klem, 1997). Some taxa, such as Aythya cf. fuligula, Anatidae cf. Tadorna sp., Porzana porzana and Anas crecca, are known as winter visitors or passage migrants. Whether this was also the case during the Pleistocene is not known. Due to small sample sizes and the absence of diagnostic species from layers $\mathrm{AH}$ 

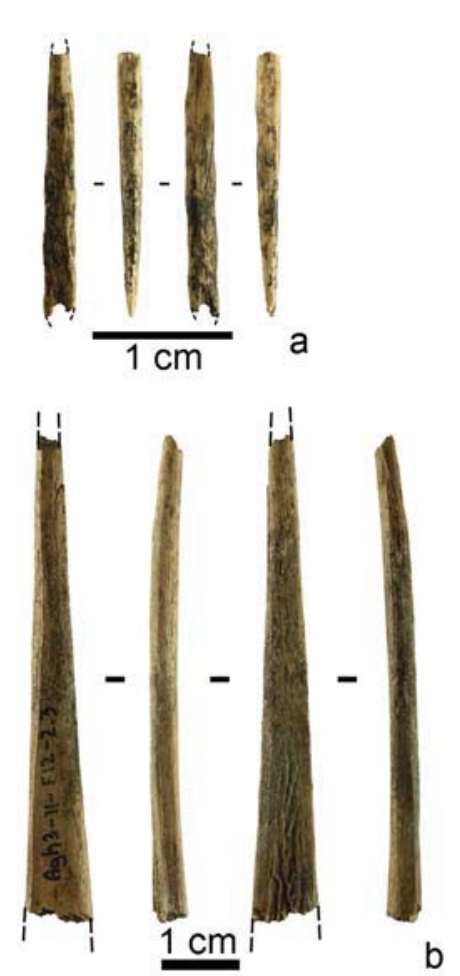
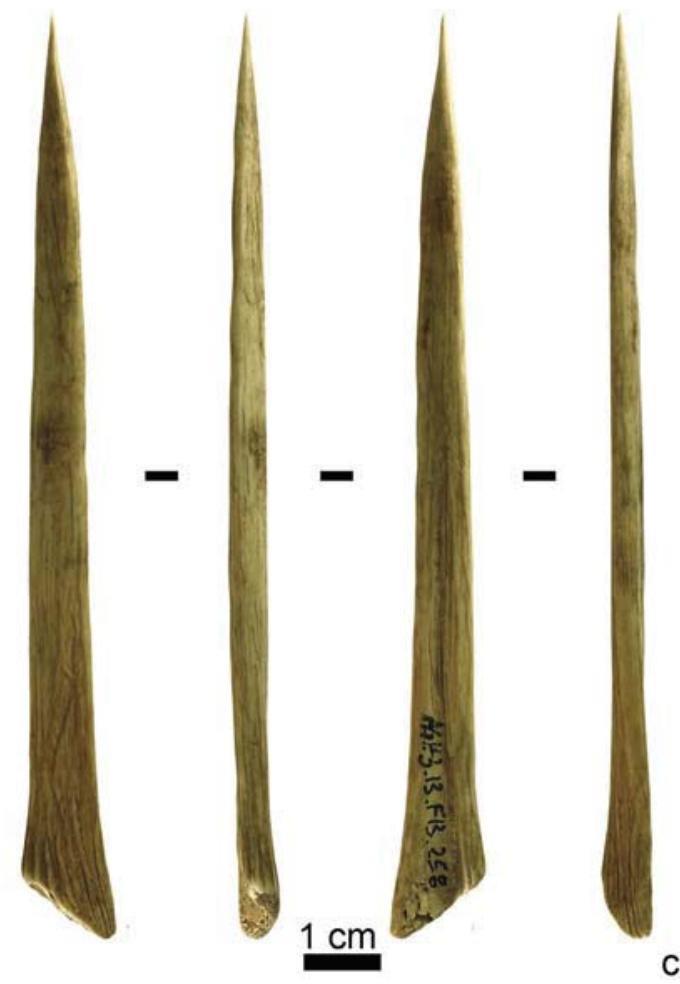

Figure 12. Organic tools from Aghitu-3: a) bone needle from AH IIId with truncated tip (top) and broken perforated end (bottom); b) bone awl from AH IIId with broken base and tip; c) complete bone point from AH IIIc showing highly polished and striated surfaces. (Photos: D. Arakelyan).

V-III, no paleoecological interpretations are given for these assemblages. However, larger samples from AH VII and VI provide more insight into the conditions that were present around the site. The Chukar partridge (Alectoris chukar) is a species with a Southern Palearctic distribution that prefers dry, rocky outcrops and sparse shrub vegetation (Stuart Baker, 1922; Watson, 1961; Naeem Awan et al., 2006). The grey partridge (Perdix perdix) is also associated with rather open environments but has a somewhat higher tolerance for cold weather and humidity than Alectoris sp. (Meriggi et al., 1991). The occurrence of larks (Alaudidae) and a possible Eurasian skylark (Alauda cf. arvensis) also suggests a relatively open landscape (Kuiper et al., 2013). On the other hand, the remains of several ducks (A. crecca, Anas platyrhynchos, Aythya sp., Aythya cf. fuligula and Anatidae cf. Tadorna sp.), a fragment of a spotted crake (Porzana porzana) and a number of waders (Scolopacidae/Charadriidae and Scolopacidae cf. Gallinago sp.) indicate the existence of shallow fresh water in the vicinity of the site (Svenson and Grant, 1999). The marsh harrier (Circus aeruginosus) is a species strongly associated with wetlands, especially reed beds, which tends to avoid woodland (Takacsova, 2007).

In sum, the avian remains suggest a temperate, open environment with the presence of some shrub, and a fresh water reservoir with riparian vegetation in the proximity of the site. A good candidate would be the Vorotan and its smaller tributaries. No significant differences were observed between AH VII and VI, while the sample sizes of the other stratigraphical units were too small for comparison.

\section{Botanical remains}

Charcoal was the most frequent botanical remain found in the archaeological horizons. The charcoal likely came from the three types of combustion features described in the section on micromorphology. Additionally the botanical remains included one piece of well-preserved, unburned wood. From sediment samples taken along the profile walls, we extracted small quantities of pollen and non-pollen palynomorphs (NPPs).

\subsection{Anthracology}

Anthracological analysis helps identify charcoal remains and characterize the nature of wood forests near a site. The analysis of the stratigraphic sequence allows us to describe taxonomic changes in woody plants and determine the local environment (Chabal et al., 1999; Asouti and Austin, 2005). In addition, charcoal remains provide for the specific characterization of available woody plants used by hunter-gatherers for fuel acquisition as well as selection patterns and recurrent practices (Asouti and Austin, 2005).

The majority of charcoal remains from Aghitu-3 were recovered during excavation as single finds. Additional samples were picked from the buckets, which were dry screened using $2 \mathrm{~mm}$ sieves. In the field, samples were wrapped in small pouches of aluminum foil for protection, then air-dried and repackaged in glass vials in the laboratory. This study is based on the analysis of 2073 charcoal fragments from $\mathrm{AH}$ VII, VI, and III. We subdivided AH III into an upper (AH IIIa-b) and lower (AH IIIc-d) portion, similar to the microfauna. Charcoal was less frequent in $\mathrm{AH} \mathrm{V}$ and IV and is excluded from this analysis.

Identification was accomplished with an optical microscope under reflected light (Olympus BX41) using 50,100, 200, and 500× magnifications. Images were taken using a scanning electron microscope (JEOL-6000) at the University Rovira i Virgili (Fig. 17). To support the identifications, we referenced several sources: 1) wood anatomy atlases (Fahn et al., 1986; Schweingruber, 1990; Benkova and Schweingruber, 2004; Schweingruber et al., 2011); 2) online databases (InsideWood, 2004; Schweingruber and 

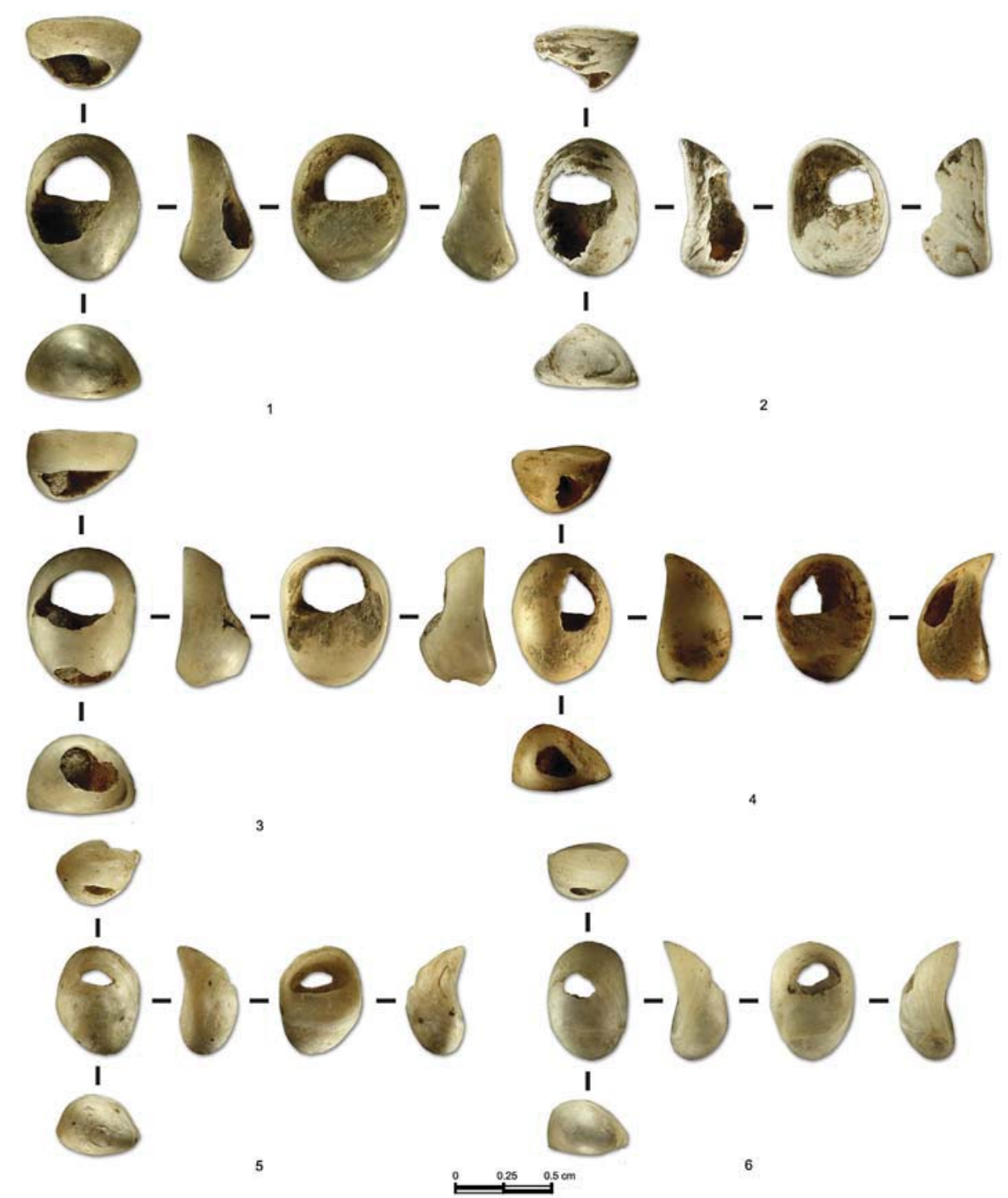

Figure 13. Six of the shell beads from Aghitu-3 (AH IIIa, IIIc, IIId) identified as the neritid gastropod Theodoxus pallasi. Shells 3 and 4 show macroscopic traces of ocher pigment, while shell 4 has several striations near the aperture. (Photos: D. Arakelyan).

Table 16

Taxonomic composition of the microfauna according to NISP and MNI.

\begin{tabular}{|c|c|c|c|c|c|c|c|c|c|c|c|c|}
\hline \multirow[t]{2}{*}{ Taxa } & \multicolumn{2}{|c|}{ AH III-upper } & \multicolumn{2}{|c|}{ AH III-lower } & \multicolumn{2}{|c|}{ AH IV } & \multicolumn{2}{|c|}{$\mathrm{AH} \mathrm{V}$} & \multicolumn{2}{|c|}{$\mathrm{AH} \mathrm{VI}$} & \multicolumn{2}{|c|}{ AH VII } \\
\hline & NISP & MNI & NISP & MNI & NISP & MNI & NISP & MNI & NISP & MNI & NISP & MNI \\
\hline \multicolumn{13}{|l|}{ Rodentia } \\
\hline Allactaga sp. & - & - & 2 & 1 & - & - & - & - & - & - & 4 & 2 \\
\hline Cricetulus migratorius & 1 & 1 & 2 & 1 & - & - & 2 & 1 & 3 & 1 & 8 & 3 \\
\hline Ellobius lutescens & - & - & - & - & - & - & - & - & - & - & 14 & 6 \\
\hline Mesocricetus brandti & 1 & 1 & 9 & 4 & 10 & 4 & 11 & 4 & 32 & 13 & 59 & 20 \\
\hline \multicolumn{13}{|l|}{ Arvicolinae } \\
\hline Arvicola amphibius & - & - & 2 & 1 & 3 & 1 & 2 & 1 & 1 & 1 & 7 & 4 \\
\hline Chionomys/Microtus & 4 & - & 42 & - & 34 & - & 16 & - & 121 & - & 96 & \\
\hline Chionomys sp. & - & - & - & 8 & - & 3 & - & 1 & - & 13 & - & 8 \\
\hline Microtus spp. & - & 3 & - & 20 & - & 11 & - & 6 & - & 39 & - & 34 \\
\hline \multicolumn{13}{|l|}{ Lagomorpha } \\
\hline Ochotona rufescens & 1 & - & 26 & 4 & 13 & 4 & 7 & 4 & 7 & 2 & 37 & 11 \\
\hline \multicolumn{13}{|l|}{ Eulipotyphla } \\
\hline Soricidae & - & - & - & - & - & - & - & - & 1 & 1 & - & - \\
\hline TOTAL & 7 & 5 & 83 & 39 & 60 & 23 & 38 & 17 & 165 & 70 & 225 & 88 \\
\hline
\end{tabular}



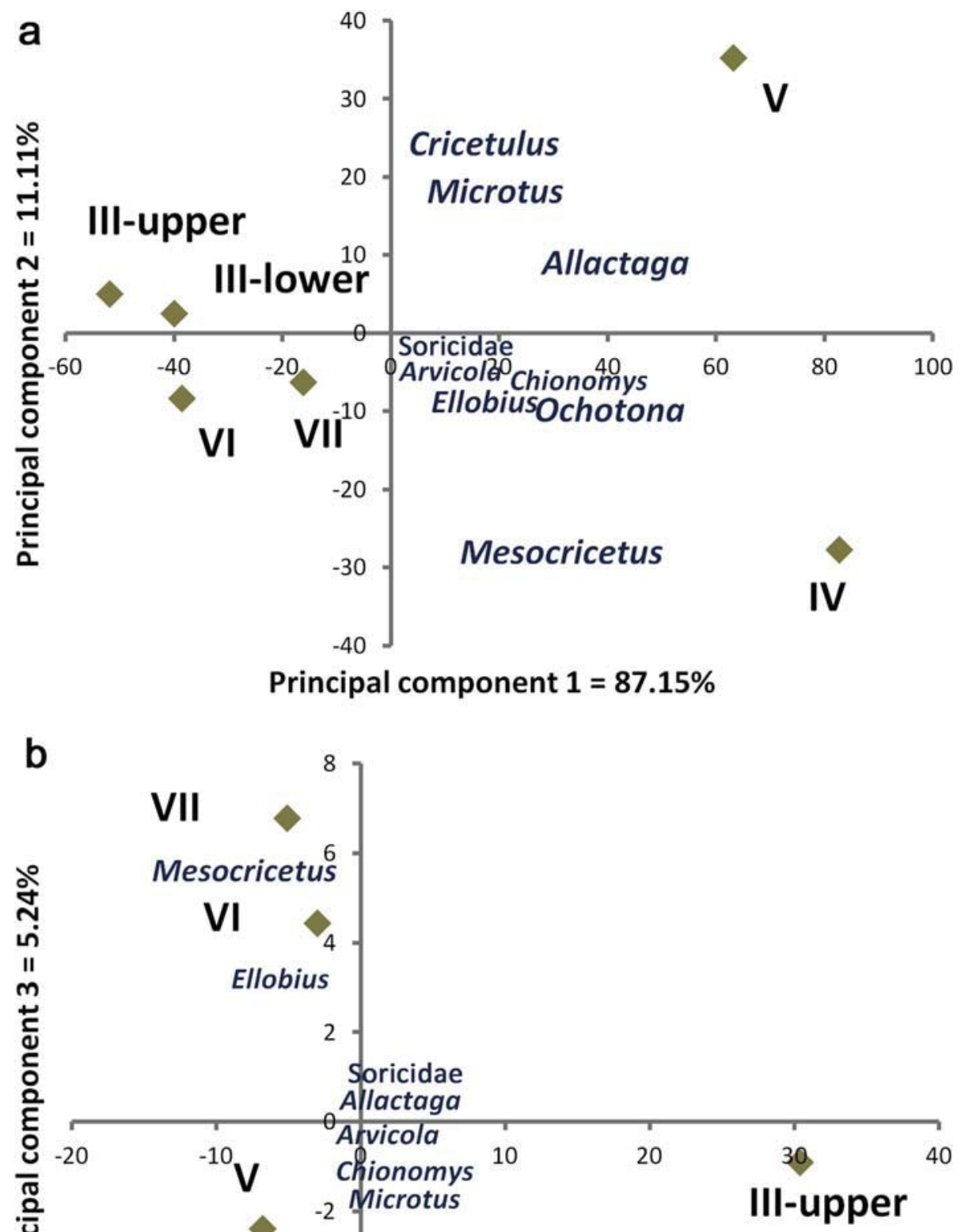

relative abundance.

Landolt, 2005; Wheeler, 2011); 3) other publications (Jansen et al., 2000; Zhang et al., 2007; Yang et al., 2010); and 4) wood slides and charcoal reference collection of the Institute of Archaeology at University College London. Each charcoal piece was fragmented by hand to obtain the three anatomical sections that permit identification of different categories including family, genus, species, or group of species. Quantification was based on the number of fragments, and relative values excluded indeterminate fragments.

The charcoal assemblage is very well preserved with low values of undetermined specimens $(2-4 \%)$ and undetermined angiosperms (4-19\%). The indeterminate fraction is affected by different types of alteration related to combustion and postdepositional processes, as well as fragmentation. While many pieces of charcoal were large, the small size of some hindered observation of the anatomical characteristics used for identification. Micro-charcoal was also observed in the palynological analysis.

The most significant taxa identified are Hippophae rhamnoides (sea-buckthorn), followed by Salix (willow), Tamarix (tamarisk), and Nitraria (nitre bush) (Fig. 18). With the exception of upper AH 
Table 17

Skeletal element composition of the microfauna according to minimum number of elements (MNE) and numbers of digested specimens.

\begin{tabular}{|c|c|c|c|c|c|c|c|c|c|c|c|c|}
\hline \multirow[t]{2}{*}{ Skeletal elements } & \multicolumn{2}{|c|}{ AH III-upper } & \multicolumn{2}{|c|}{ AH III-lower } & \multicolumn{2}{|c|}{ AH IV } & \multicolumn{2}{|c|}{$\mathrm{AH} \mathrm{V}$} & \multicolumn{2}{|c|}{$\mathrm{AH} \mathrm{VI}$} & \multicolumn{2}{|c|}{ AH VII } \\
\hline & total & digested & total & digested & total & digested & total & digested & total & digested & total & digested \\
\hline Maxilla & 5 & - & 35 & - & 10 & - & 6 & - & 36 & - & 36 & - \\
\hline Mandible & 7 & - & 55 & - & 20 & - & 13 & - & 79 & 1 & 113 & - \\
\hline Incisor & 11 & - & 50 & - & 29 & 1 & 12 & - & 108 & - & 114 & - \\
\hline Molar & 7 & - & 56 & - & 60 & 8 & 38 & 5 & 164 & 8 & 226 & 3 \\
\hline Humerus & 12 & 2 & 55 & 2 & 9 & 1 & 6 & - & 139 & 3 & 94 & - \\
\hline Radius & 2 & - & 4 & - & 1 & - & 1 & - & 14 & - & 20 & - \\
\hline Ulna & 4 & - & 6 & 1 & 1 & - & 4 & - & 41 & - & 36 & - \\
\hline Femur & 12 & - & 43 & 3 & 16 & 6 & 7 & - & 149 & 12 & 125 & 3 \\
\hline Tibia & 5 & - & 47 & 1 & 9 & - & 6 & - & 116 & 1 & 92 & - \\
\hline Scapula & 1 & - & 13 & - & 1 & - & - & - & 7 & - & 12 & - \\
\hline Pelvis & 3 & - & 23 & - & 6 & - & 3 & - & 45 & - & 63 & - \\
\hline TOTAL & 69 & 2 & 387 & 7 & 162 & 16 & 96 & 5 & 898 & 25 & 931 & 6 \\
\hline
\end{tabular}

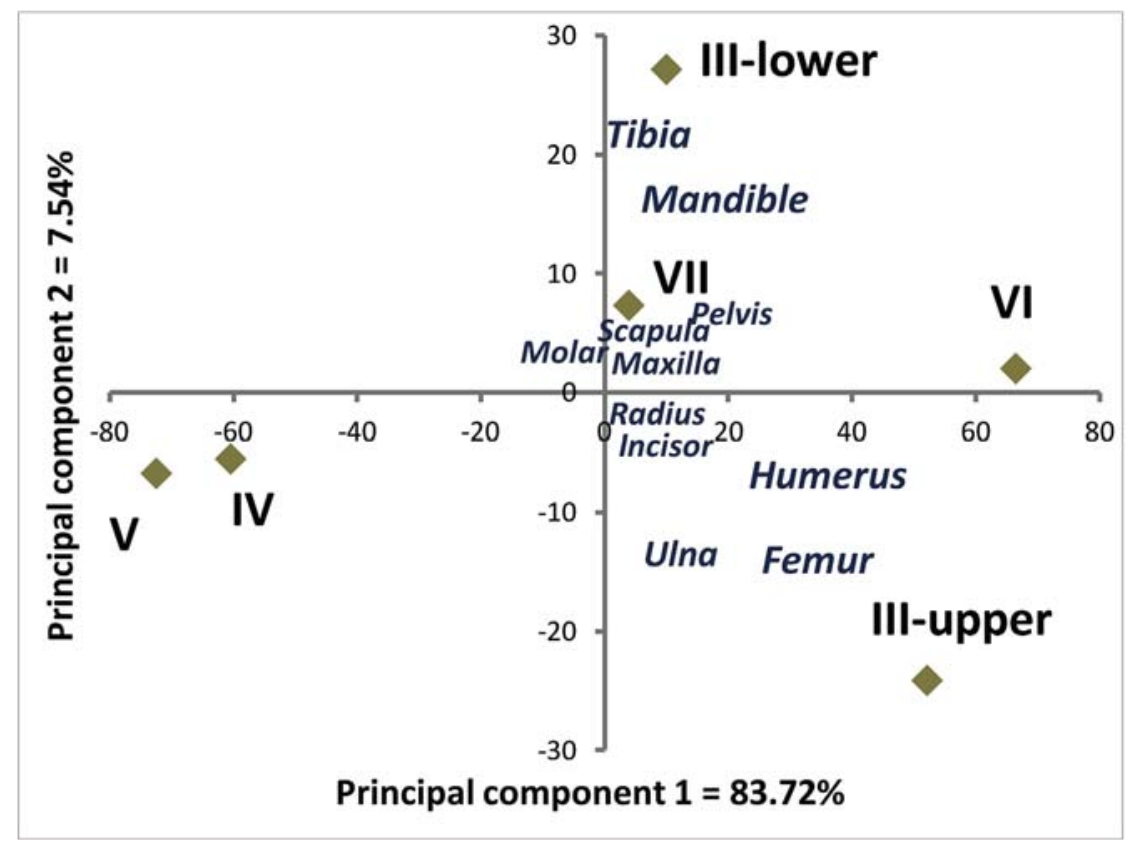

Figure 15. Skeletal element composition of micromammals in the different stratigraphic units as shown in a principal component scatterplot based on percent MNE (for method of calculation see Andrews, 1990).

Table 18

Proportions of complete elements and the smallest fragments thereof for the major skull and post-cranial elements of the microfauna. Definition of completeness: i) mandible - stages A-B (Andrews, 1990, Fig. 3.12); ii) maxilla - stages C-D (Andrews, 1990, Fig. 3.11); iii) post-crania - complete element. Definition of fragmentation: i) mandible $\sim 1 / 3$ of alveolar region; ii) maxilla $\sim 1 / 3$ of alveolar region; and iii) postcrania $\sim 1 / 4$ of element.

\begin{tabular}{lcccccc}
\hline \% Completeness & AH III & AH IV & AH V & AH VI & AH VII & St. Dev. \\
\hline Maxilla & 15 & 40 & - & 25 & 42 & 17 \\
Mandible & 17 & 60 & 69 & 28 & 18 & 25 \\
Humerus & 46 & - & - & 9 & 41 & 23 \\
Radius & 100 & - & - & - & 25 & 43 \\
Ulna & 27 & - & - & 2 & 17 & 12 \\
Femur & 26 & - & - & 12 & 38 & 17 \\
Tibia & 17 & - & - & 3 & 20 & 10 \\
\hline \% Fragmentation & AH III & AH IV & AH V & AH VI & AH VII & St. Dev. \\
\hline Maxilla & 24 & 20 & 50 & 33 & 22 & 12 \\
Mandible & 9 & 5 & 8 & 11 & 10 & 2 \\
Humerus & 9 & - & - & 1 & 5 & 4 \\
Radius & - & - & - & 14 & 10 & 7 \\
Ulna & - & - & - & 5 & 6 & 3 \\
Femur & 13 & - & - & 3 & 11 & 6 \\
Tibia & 9 & - & - & 8 & 11 & 5 \\
\hline
\end{tabular}

III, $H$. rhamnoides shows the highest values throughout the sequence, up to $80 \%$ in AH VI. Salix is also present in all layers, increasing from $8 \%$ in $\mathrm{AH}$ VII to $30 \%$ in upper AH III. Tamarix is absent from AH VII and VI and then increases from $10 \%$ in AH IIId to $22 \%$ in upper AH III. Finally, Nitraria is mainly present in AH VII and VI, showing values up to $31 \%$. In summary, $H$. rhamnoides and Nitraria decrease moving up the sequence, while Salix, Tamarix, and "other taxa", including Betula/Alnus, Quercus sp. deciduous and Maloideae, increase.

Table 19

NISP of identified fish, amphibians and reptiles.

\begin{tabular}{llllc}
\hline Microfauna & \multicolumn{1}{c}{ Taxa } & Common name & AH III & AH VII \\
\hline Fish & Salmo sp. & Brown trout & 18 & 22 \\
Amphibians & Rana macrocnemis & Brown frog & - & 2 \\
& Ranidae indet. & Brown or green & 1 & - \\
& (Rana vel. Pelophylax) & frog & & \\
& Bufotes variabilis & Green toad & 1 & - \\
\multirow{5}{*}{ Reptiles } & Anura indet. & Frog indet. & 2 & 2 \\
& Lacertilia indet. & Lizard indet. & 1 & - \\
& & TOTAL & 23 & 26
\end{tabular}


Table 20

NISP of identified avian taxa. Size category I = approximately size of starling (Sturnus vulgaris), size category II = approximately size of sparrow (Passer domesticus), size category III = approximately size of robin (Erithacus rubecula).

\begin{tabular}{|c|c|c|c|c|c|c|c|c|c|c|c|}
\hline \multirow[t]{2}{*}{ Common name } & \multirow[t]{2}{*}{ Taxon/Order/Family } & \multicolumn{2}{|c|}{ AH III } & \multicolumn{2}{|c|}{ AH IV } & \multicolumn{2}{|c|}{$\mathrm{AH} \mathrm{V}$} & \multicolumn{2}{|c|}{ AH VI } & \multicolumn{2}{|c|}{ AH VII } \\
\hline & & $n$ & $\%$ & $n$ & $\%$ & $n$ & $\%$ & $n$ & $\%$ & $n$ & $\%$ \\
\hline Perching bird & Passeriformes & & & & & 1 & $9 \%$ & 12 & $23 \%$ & 9 & $6 \%$ \\
\hline Perching bird - size category I & Passeriformes & & & & & & & 3 & $6 \%$ & 8 & $5 \%$ \\
\hline Perching bird - size category II & Passeriformes & 29 & $78 \%$ & 2 & $100 \%$ & 8 & $73 \%$ & 8 & $15 \%$ & 36 & $23 \%$ \\
\hline Perching bird - size category III & Passeriformes & 7 & $19 \%$ & & & & & 3 & $6 \%$ & 6 & $4 \%$ \\
\hline Finch? & cf. Fringilidae & & & & & & & & & 4 & $3 \%$ \\
\hline Swallow & Hirundinidae & & & & & & & & & 1 & $0.6 \%$ \\
\hline Lark & Alaudidae & & & & & & & & & 1 & $0.6 \%$ \\
\hline Lark? & cf. Alaudidae & & & & & & & 1 & $2 \%$ & & \\
\hline Eurasian skylark? & Alauda cf. arvensis & & & & & 1 & $9 \%$ & & & & \\
\hline Raven & Corvus corax & & & & & & & & & 1 & $0.6 \%$ \\
\hline Grey partridge & Perdix perdix & & & & & & & & & 1 & $0.6 \%$ \\
\hline Chukar partridge & Alectoris chukar & & & & & & & & & 2 & $1.3 \%$ \\
\hline Partridge & Alectoris sp. & & & & & & & & & 1 & $0.6 \%$ \\
\hline Partridge & Alectoris sp./Perdix sp. & & & & & & & 1 & $2 \%$ & 2 & $1.3 \%$ \\
\hline Gamefowl - approx. partridge size & Galliformes & & & & & & & & & 1 & $0.6 \%$ \\
\hline Gamefowl - approx. pheasant size & Galliformes & & & & & & & 1 & $2 \%$ & 3 & $2 \%$ \\
\hline Diving duck & Aythya sp. & & & & & & & & & 1 & $0.6 \%$ \\
\hline Tufted duck? & Aythya cf. fuligula & & & & & & & & & 1 & $0.6 \%$ \\
\hline Teal & Anas crecca & & & & & & & 1 & $2 \%$ & 1 & $0.6 \%$ \\
\hline Mallard & Anas platyrhynchos & & & & & & & & & 1 & $0.6 \%$ \\
\hline Mallard? & Anas cf. platyrhynchos & & & & & & & & & 1 & $0.6 \%$ \\
\hline Shelduck? & Anatidae cf. Tadorna sp. & & & & & & & & & 1 & $0.6 \%$ \\
\hline Duck & Anatidae & & & & & & & & & 2 & $1.3 \%$ \\
\hline Marsh harrier & Circus aeruginosus & & & & & & & & & 1 & $0.6 \%$ \\
\hline Raptor - approx. Buzzard size & Accipitridae & & & & & & & & & 1 & $0.6 \%$ \\
\hline Spotted crake & Porzana porzana & & & & & & & & & 1 & $0.6 \%$ \\
\hline Wader & Scolopacidae or Charadriidae & & & & & & & 1 & $2 \%$ & 8 & $5 \%$ \\
\hline Snipe? & Scolopacidae cf. Galinago sp. & & & & & & & 2 & $4 \%$ & 4 & $3 \%$ \\
\hline Common swift & Apus apus & & & & & & & 5 & $10 \%$ & & \\
\hline Indeterminate bird & Aves indet. & 1 & $3 \%$ & & & 1 & $9 \%$ & 14 & $27 \%$ & 60 & $38 \%$ \\
\hline TOTAL & & 37 & $100 \%$ & 2 & $100 \%$ & 11 & $100 \%$ & 52 & $100 \%$ & 159 & $100 \%$ \\
\hline
\end{tabular}

H. rhamnoides, Nitraria, and Tamarix are shrubs or small trees that grow in semi-arid or sub-humid (xeric) environments and tolerate salty soils. $H$. rhamnoides and Tamarix as well as Salix grow close to water sources. $H$. rhamnoides is a cold-tolerant, heliophytic species common in the European UP during MIS 2 (29-14,000 BP) and is frequently associated with a landscape dominated by conifers (Vernet, 1997; Willis et al., 2000; González-Sampériz et al., 2010; Uzquiano, 2014). The nearest long pollen sequence

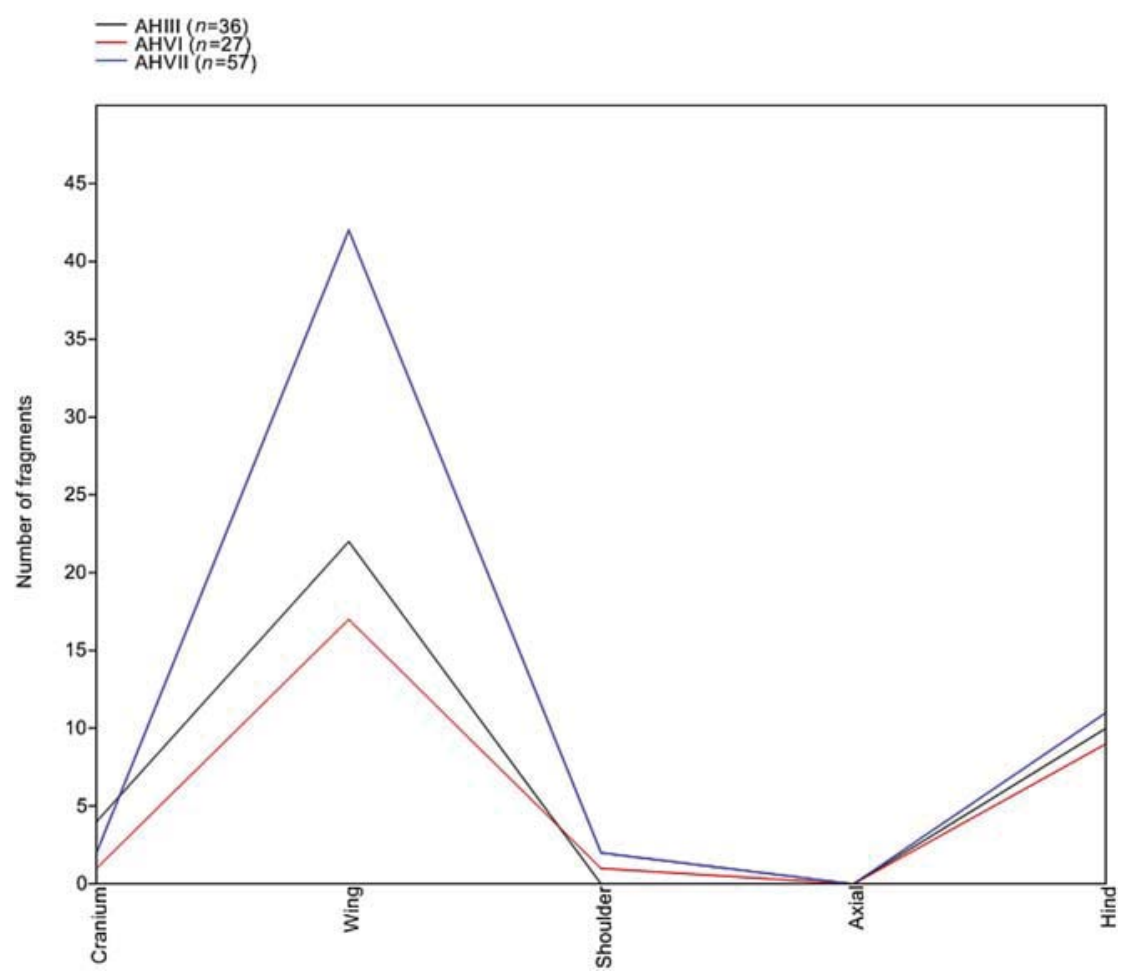

Figure 16. Relative abundance of avian skeletal elements by anatomical region in perching birds: shoulder $=$ shoulder girdle; axial $=$ axial skeleton; hind $=$ hind limb. 


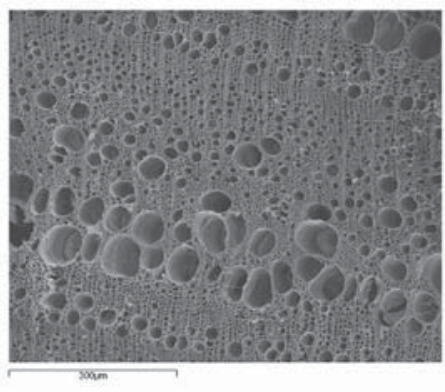

a

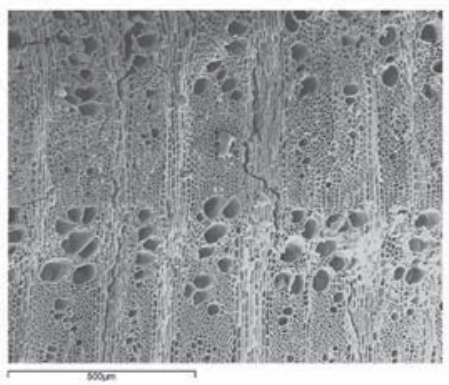

C

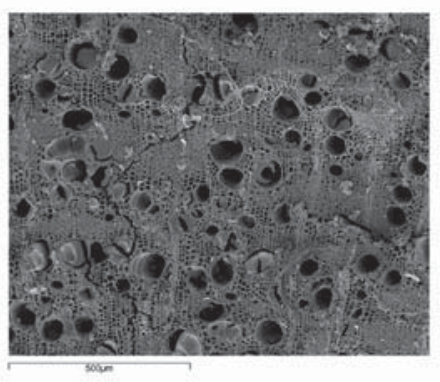

e

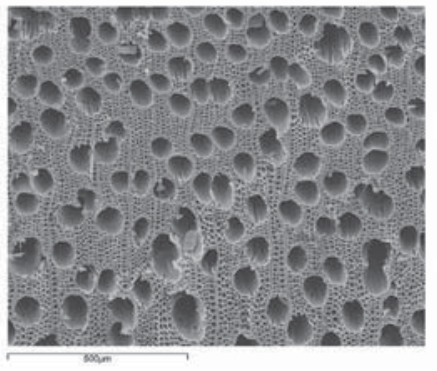

g

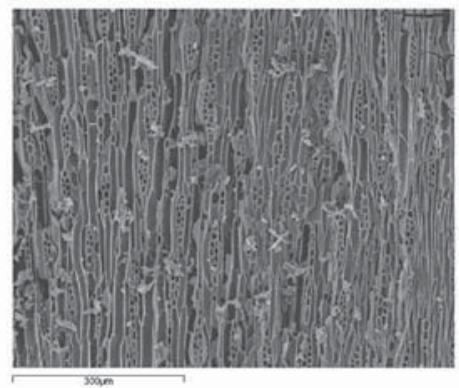

b

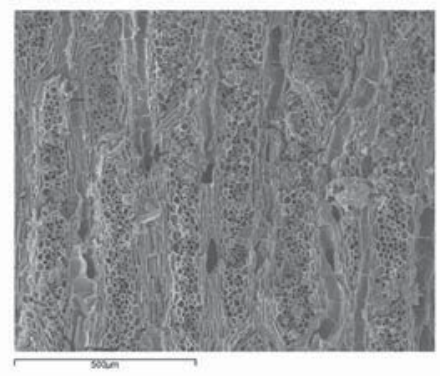

d

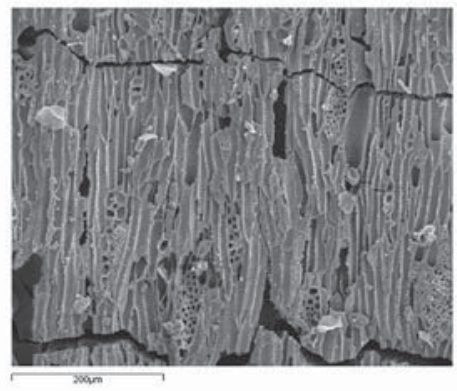

f

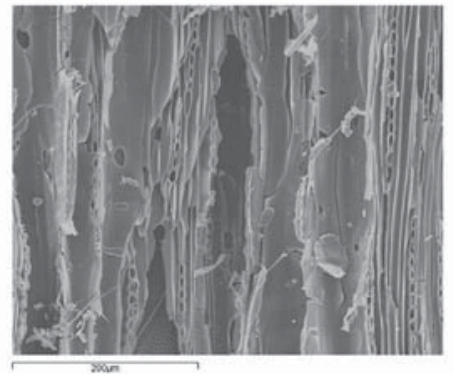

h

Figure 17. SEM of the most common varieties of charcoal identified at Aghitu-3: Hippophae rhamnoides - a) transversal section showing ring porous distribution; b) tangential section showing bi-seriated storied rays; Tamarix - c) transversal section showing ring porous distribution; d) tangential section showing multi-seriated large rays; Nitraria - e) transversal section showing vessel distribution in dendritic pattern and paratracheal parenchyma; f) tangential section showing bi-seriated heterogeneous rays with occasional sheath cells; Salix - g) transversal section showing diffuse pore distribution; h) tangential section showing uni-seriated heterogeneous rays. (Photos: E. Allué). 


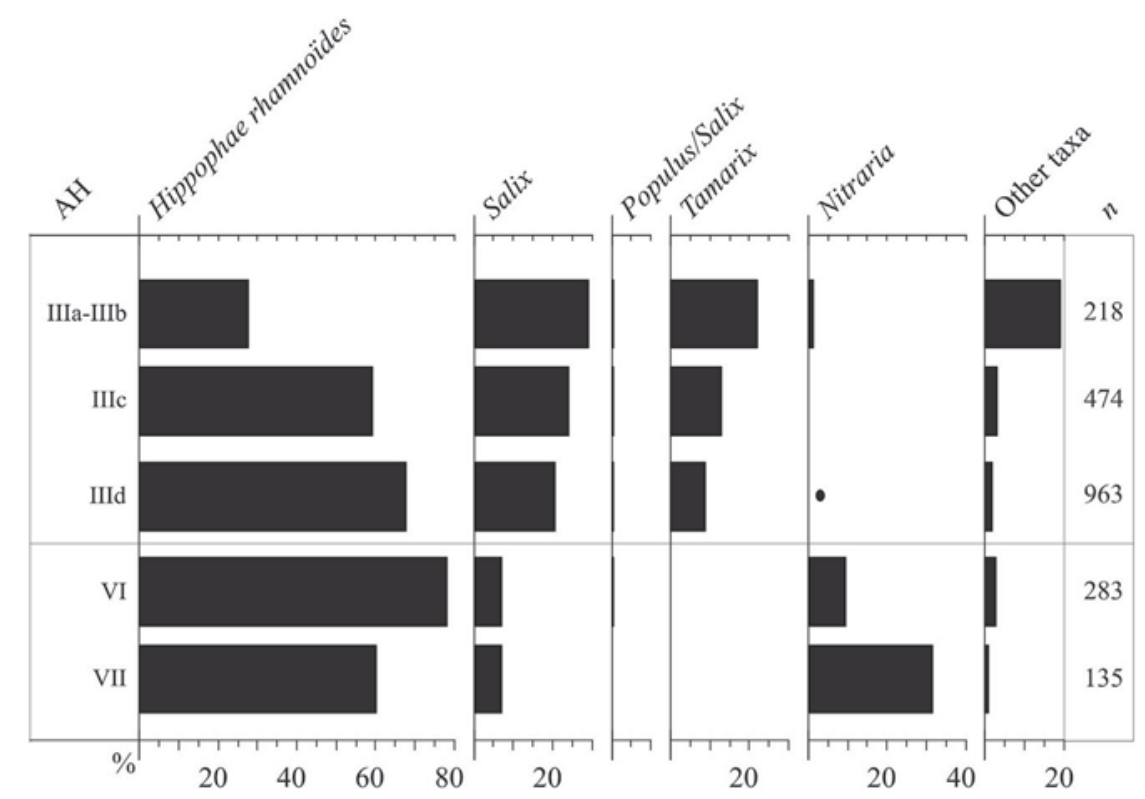

Figure 18. Graph of anthracological results for the main layers of Aghitu-3 showing percentages of charcoal based on the total number of identified taxa ( $n$ ). "Other taxa" includes Betula/Alnus, Quercus sp. deciduous and Maloideae.

providing comparable data comes from Lake Urmia in Iran, about 200 km SW of Aghitu-3 (Djamali et al., 2008). Deposits from Lake Urmia attest to the predominance of a desert-like or semi-desert environment from about 60 to 20,000 BP. The authors report that the high proportion of $H$. rhamnoides in the region around Lake Urmia was accompanied by other semi-desert herbaceous plants. These results suggest that temperatures were generally colder than today and that soil erosion increased, perhaps due to fluvial activity. In the Vorotan valley, the vegetation recorded in the charcoal assemblage of Aghitu-3 suggests that $H$. rhamnoides served as a pioneer taxon in an open shrubby landscape influenced by cold semi-desert conditions.

The increase of Salix and Tamarix and corresponding decrease of Nitraria in AH III might also suggest environmental change characterized by a modification of the fluvial regime. This could result from local environmental variation, for example, changes in water flow or temperature of the Vorotan, or competition between Tamarix and Nitraria within the same ecotone related to soil salinity (Liu and Zhao, 2009). Changes in fuel acquisition patterns could also explain this trend, but the recurrent use of $H$. rhamnoides throughout the sequence indicates that people generally preferred this species over other woody resources. The overall predominance of $H$. rhamnoides suggests that it was always the most abundant and available species, even in upper AH III where its proportion is lowest.

Firewood selection patterns among Paleolithic groups are usually based on collection of the most abundant species available closest to a site (Théry-Parisot, 2001; Asouti and Austin, 2005). Wood is chosen as a major fuel when plentiful, whereas other types of fuel (e.g., bone or grass) are used when wood is scarce or set aside for other purposes, such as to provide light (Marquer et al., 2010; Allué et al., 2012). In general, trees and shrubs with a high rate of dead wood production are more available for immediate use (Allué et al., 2012; Solé et al., 2013). H. rhamnoides is clearly the most dominant species at Aghitu-3, and served as fuel over the entire period of occupation, but it also produces edible fruit, as discussed below. Thus, people may have exploited sea-buckthorn for multiple purposes.

The use of Salix as fuel is well recorded in areas where wood is available only in riverside forests, as is the case at some European
Paleolithic sites (Théry-Parisot and Texier, 2006; Uzquiano, 2014). On the other hand, even at sites where Salix is present, other types of wood such as conifer are preferentially selected for fuel when available (Théry-Parisot and Texier, 2006; Allué et al., 2012, 2017). Therefore, the increased use of riverside species such as Salix or Tamarix in AH III might be interpreted as a response to the reduced availability of other types of wood.

In addition to charcoal remains, near the top of $\mathrm{AH}$ VI we discovered an unburned piece of wood $(4.9 \mathrm{~cm})$ which we identified as the inner bark of $H$. rhamnoides. This corresponds with the results of the anthracological analysis. The soft bast fibers of the inner bark of sea-buckthorn can be used in the manufacture of rope or burlap. Furthermore, the fruits of this species are rich in linoleic fatty acid and vitamin C (app. $900 \mathrm{mg} / 100 \mathrm{~g}$ ), both of which are essential for human metabolism. The fruits ripen in September and hang on the bush through winter, though they taste less acidic when frozen or cooked (Bickel-Sandkötter and Kiefer, 2001). Twigs and leaves contain tannins, which are astringent and vermifuge (Chiej, 1984). Finally, oil from the fruits can alleviate skin diseases. Thus, the presence of charcoal and inner bark supports the idea that H. rhamnoides had many uses at Aghitu-3.

\subsection{Palynology including non-pollen palynomorphs (NPPs)}

The investigation of NPPs combined with pollen analysis helps describe general environmental conditions at the time of sediment deposition (cf. van Geel, 2006) and may illuminate human activities in archaeological contexts (e.g., Kvavadze et al., 2009; Kvavadze and Kakhiani, 2010). NPPs are categorized into groups such as plant remains (e.g., pollen, spores, charred and uncharred wood, plant epidermis), algal and fungal remains, and zoomorphs (e.g., insect parts, coprolites of insects). Minerals remaining after chemical treatment are not considered.

For NPP and pollen analysis of the samples collected from Aghitu-3, we processed $50 \mathrm{~g}$ of sediment because we anticipated low concentrations. The material was crushed, weighed, and treated with $\mathrm{HCl}$ and $\mathrm{HF}$ to remove carbonates and silica. Lycopodium (clubmoss) tablets were added as control spikes for the calculation of absolute NPP and pollen concentrations. After 
treatment with these acids, the residues were cleaned by sieving through a $6 \mu \mathrm{m}$ nylon mesh and centrifuged with a heavy liquid (polytungstate). Two strew mounted slides were prepared from each residue with glycerin gelatin as a mounting medium. Concentrations per gram of sediment were calculated based on the counted spikes and visualized with TILIA and TG View 2.0.2 software (Grimm, 2004). For statistical purposes, NPP and pollen analyses aimed for a minimum count of 200 palynomorph grains. For NPPs, we notice a strong anthropogenic influence based on increased amounts of micro-charcoal in most archaeological layers (Fig. 19). For pollen, only one sample had >200 grains, but we present the other data to provide qualitative information about vegetation (Fig. 20).

In $\mathrm{AH} \mathrm{VI}$, increased amounts of plant remains and freshwater palynomorphs indicate humid conditions. Sample AB11/08/27-41 (AH VI; $-436 \mathrm{~cm}$ ) yielded $>200$ pollen grains with equal proportions of deciduous forest, steppic vegetation, and the herbaceous family Asteraceae. This trend is mirrored by samples $A B 11 /$ 08/27-40 (AH VI; $-428 \mathrm{~cm}$ ) and AB11/08/27-20 (AH VI; $-318 \mathrm{~cm}$ ) and suggests a temperate and fairly humid climate. A high proportion of riparian vegetation with reeds (Phragmites), cattails (Typha), calamus (Acorus), and other freshwater NPPs indicate a small lake or gently flowing river near the cave.

In $\mathrm{AH} \mathrm{V}$ and IV, low numbers of palynomorphs make it more difficult to interpret the results. The NPP signal, especially based on freshwater algae, shows the fluctuating influence of humidity. This trend relates less likely to global climatic changes and more likely to local water availability. We note a difference in pollen samples AB11/ 08/27-15 (AH Vc; -252 cm) and AB11/08/27-06 (AH IV; -185 cm), as compared to the deeper samples. Despite their low counts, both samples show a predominance of pine (Pinus), indicating a cooler but still humid climate regionally, alongside deciduous forest and steppic elements. Pollen sample AB11/08/27-05 (AH IV; -166 cm) shows a high proportion of Asteraceae, which indicates an open landscape. However, in this case, we interpret the signal to reflect the selective preservation of these resistant pollen grains.

Near the top of AH IV, increased amounts of freshwater algae among the NPPs point to high humidity close to the cave, perhaps a nearby stream or swampy area, while high values of plant and insect remains may indicate somewhat milder conditions. As the deposition of AH III commences, indicators of humidity disappear, which suggests a climatic shift with noticeably drier conditions.

\section{Synthesis and discussion}

Aghitu-3 Cave documents the first appearance of the UP in the Armenian Highlands and is coupled with a detailed paleoenvironment record. The site shows no indication of MP occupation, although occasional Mousterian artifacts are found scattered across the surrounding landscape. Based on the presence of a distinctly UP set of artifacts coupled with radiocarbon dating results, we interpret the evidence from Aghitu-3 as the first occurrence of Homo sapiens in the Armenian Highlands. The 5.5-m-thick sequence allows us to examine variation in the behavior of the huntergatherers who inhabited the region starting 39,000 years ago and to observe their response to environmental change over the following 15,000 years. In the next sections, we synthesize the results and compare our data to contemporaneous sites in neighboring regions. It is suggested that climate change played an important role in stimulating UP settlement of this region, albeit in complex and indirect ways.

The deepest layer is AH VII and dates to $39-36,000$ cal BP. A basal lag deposit provides ample remains of microfauna but no evidence of human occupation. Above this lag deposit, we observe the earliest evidence of human occupation at Aghitu-3, as evinced by two modes of lithic production. The first employs unidirectional reduction to create bladelets, while the second makes use of a bidirectional concept to produce blades from a single removal surface. The low number of artifacts in this horizon makes it difficult to assess lithic production in greater detail. Lithic raw material was obtained predominantly from regional volcanic sources, representing $99 \%$ of the obsidian. Chert artifacts are rare, comprising just $3 \%$ of the lithic assemblage.

Fauna and charcoal are sparse in AH VII, and no combustion features are preserved. The fauna consists mainly of Ovis/Capra and equids, but clear indicators of human activity such as burning or cut marks are lacking. Based on the micromammals, we note climatic conditions that are near-modern, as indicated by the brief presence of mole voles (E. lutescens) and relatively high abundance of Brandt's hamsters ( $M$. brandti). Avian remains attest to a mosaic of landforms in the vicinity, while fish remains point to the nearby Vorotan River. Charcoal shows that the percentage of Nitraria peaks in this layer, while Salix is lowest. Nonetheless, Hippophae is the type of wood people most often selected for burning. Pollen and NPPs are not abundant.

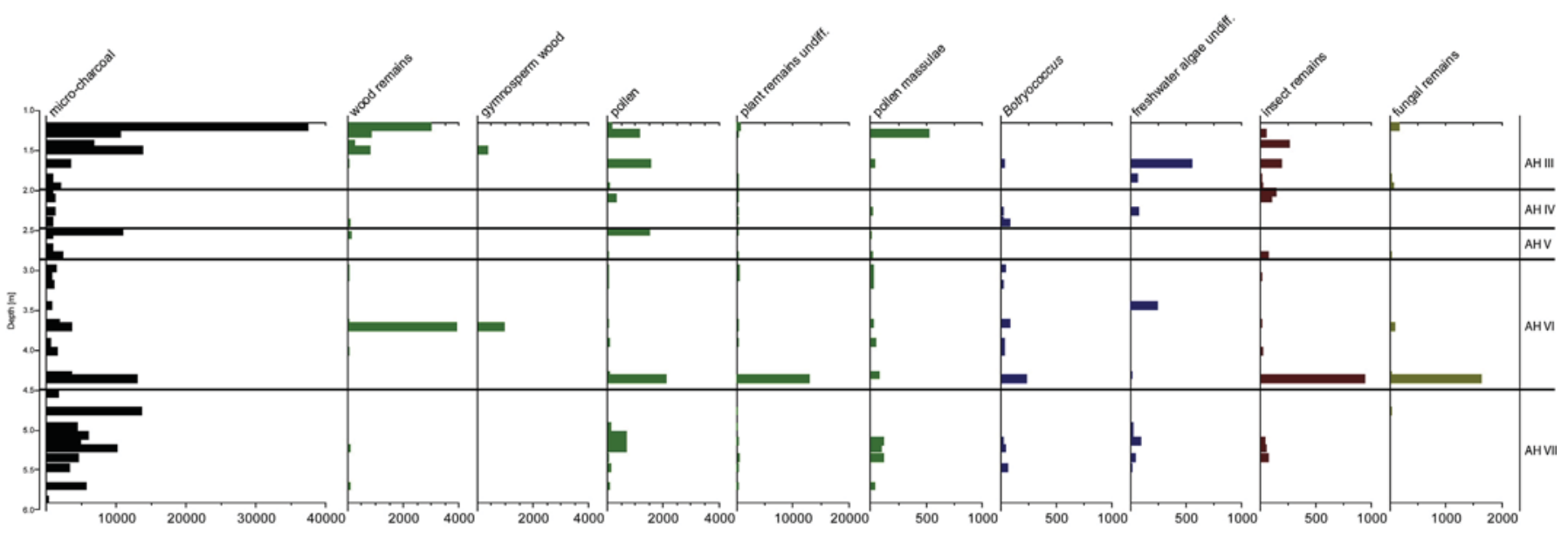

NPP concentrations [grains per gram sediment]

Figure 19. Concentrations of NPPs and pollen with respect to depth. NPP concentrations show highest values for micro-charcoal (black) in AH VII and III. Plant remains (green) and freshwater NPPs (blue) indicate more humid conditions for AH VI and IV. (For interpretation of the references to colour in this figure legend, the reader is referred to the web version of this article). 


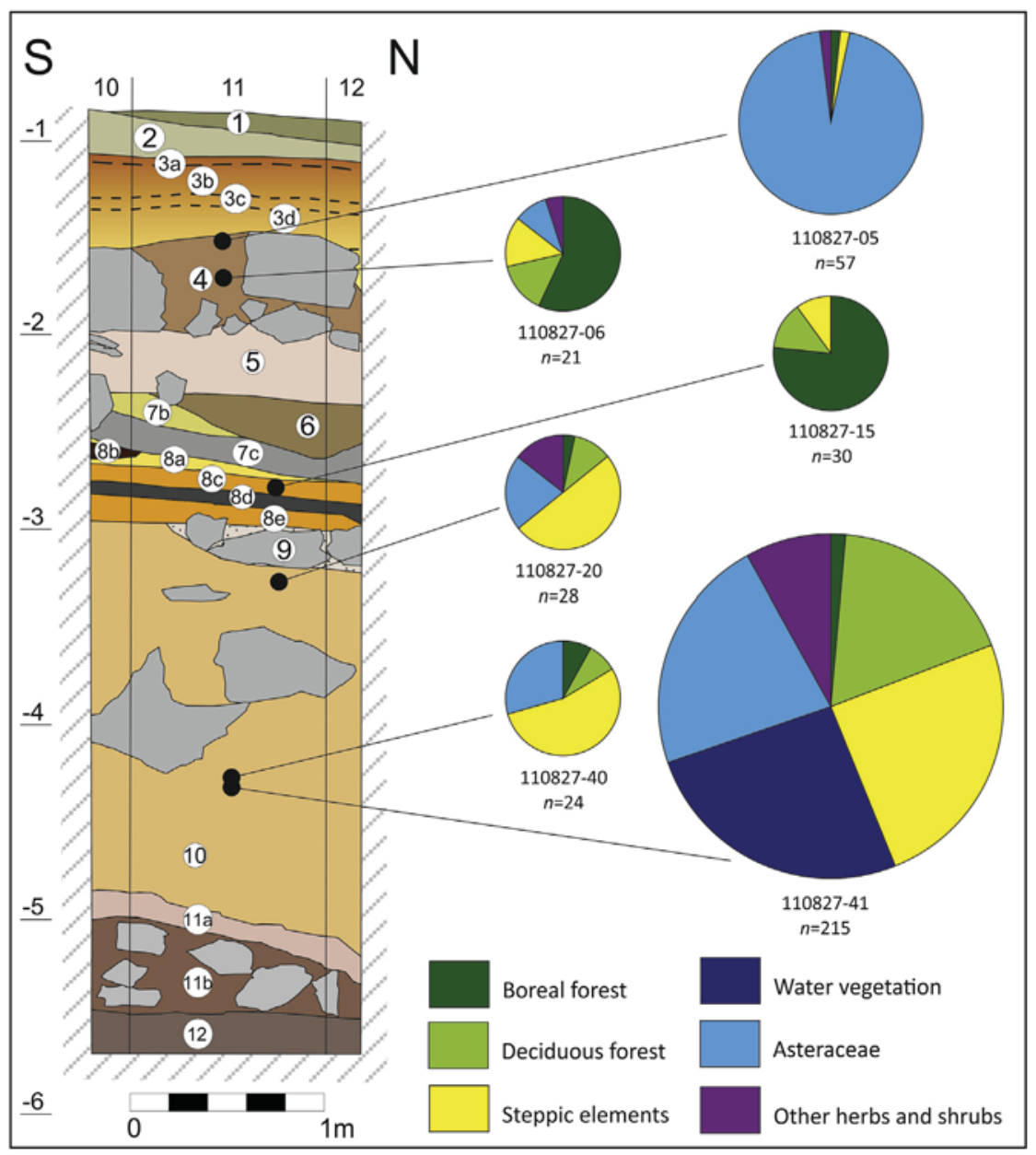

Figure 20. Relative abundances of the preferred ecology of the counted pollen taxa. The size of the diagrams is proportional to the number ( $n$ ) of pollen grains counted per sample.

The thickest layer, AH VI, dates to 36-32,000 cal BP and consists mainly of fine sediment. We see increased evidence for intermittent human occupation as the number of all find categories rises. Discrete concentrations of lithics occur around intact combustion features. Occupation appears punctuated, with single features isolated in space and time. The unidirectional mode of laminar reduction first detected in AH VII dominates the assemblage, while laterally retouched and backed bladelets become the most common types of stone tools. Obsidian remains the most frequent raw material, but the highest percentage of chert (31\%) comes from this layer. Like AH VII, regional sources account for $99 \%$ of obsidian artifacts.

The fauna of AH VI is also dominated by Ovis/Capra, but with few equid remains. Bone preservation is poorer than in AH VII. Paleoecological indicators generally point towards continuation of warm, moist climatic conditions. The avian fauna suggests a temperate environment with an open landscape of shrubs and riparian vegetation. Charcoal of $H$. rhamnoides peaks in this layer. The bestpreserved pollen data from the sequence indicate the presence of a mosaic landscape with an even distribution of elements from steppe and deciduous forest, among others. A high proportion of riparian vegetation with reeds suggests the presence of a small lake or gently flowing river close to the cave. In fact, one environmental reconstruction (S. Nahapetyan, pers. comm.) places the paleoVorotan next to the cave at this time, before the river cut its modern valley. Nonetheless, fish remains are not present.
At the top of AH VI, a massive rockfall up to 2-m-thick creates a wedge of debris that divides the site. Inside the cave, sediment began to accumulate through surface sheet flow, while the rockfall protected these deposits from subsequent erosion. The cause of the rockfall cannot be pinpointed, but triggers may include earthquakes, perhaps related to volcanic activity, or intensified cycles of freezing and thawing.

Layers AH V-IV date to 32-29,000 cal BP and document infrequent human presence with very few finds. Sandwiching AH V, the lower black and upper gray tephra layers indicate two phases of regional trachy-andesitic volcanism. Analysis of the micromammals shows an increasing proportion of Afghan pika (O. rufescens), a sign of cooling. The microbotanical remains also point to a cooling trend with fluctuating amounts of moisture, and the pollen spectra show an increase in pine. Since the counts are low and this pollen has a potential for long-distance transport, these data provide only a general indication.

The uppermost Paleolithic layer, AH III, dates to 29-24,000 cal $\mathrm{BP}$ and documents four phases of more intense occupation at Aghitu-3. The silty sediment is interlayered with horizontal-lying plates of basalt, which we interpret as frost-shatter from the cave's roof. Four sublayers (AH IIIa-d) document more or less continuous concentrations of lithics, bones, and charcoal. Obsidian dominates the lithic assemblages, and unidirectional bladelet production is focused on the manufacture of laterally retouched and backed bladelets. The key difference in AH III is that $8 \%$ of 
obsidian comes from distant to very distant sources, some $>250 \mathrm{~km}$ away, located along two directional axes of transport-to the northwest and southwest. Bone tools make their first appearance, including an eyed needle and a polished bone point. These tools suggest the manufacture of complex clothing. The presence of shell beads, two stained with ocher, adds a third axis of transport-eastward towards the Caspian Basin. The beads complement the eyed needle and support the notion that people used the shells as ornaments to adorn clothing or strung them into necklaces. The appearance of these new behaviors at Aghitu-3 may have spread through greater social interactions. It is possible that such behaviors existed earlier in the sequence. However, the low number of finds in AH VII and VI reduces the likelihood of retrieving evidence for such behaviors.

The fauna of AH III consists mainly of Ovis/Capra and equids, suggesting a broad hunting strategy aimed at capturing these species. Trout remains from this layer support the impression of a more diversified diet. Their reconstructed body size $(40 \mathrm{~cm})$ is larger than what we estimate for the natural accumulation of basal AH VII $(30 \mathrm{~cm})$ and may result from people selecting larger fish. The proportion of the Afghan pika is highest, indicating a rugged, open landscape consistent with colder climatic conditions. Although the site is located at $1601 \mathrm{~m}$, the micromammalian spectrum fits better with an elevation above $2000 \mathrm{~m}$, implying climatic conditions colder than today. Charcoal shows its highest diversity in this layer, as the proportions change: Salix, Tamarix, and other woods peak, while H. rhamnoides and Nitraria reach their lowest levels.

Across the sequence from AH VII-III, the climate becomes colder, yet the intensity of occupation increases as shown by measures of both lithic density and time-averaged lithic density (Table 21). The likelihood that different groups of people interacted across large distances increases, although we cannot determine whether the movement of materials indicates actual movement of people or exchange with other groups. Regardless, the long-distance transport of both obsidian and shell supports increasing interaction among groups in at least three directions: northwest, southwest, and east. Unidirectional bladelet technology is present across the entire sequence of 15,000 years. The spectrum of hunted animals also does not vary greatly; only the proportions of taxa differ. These data suggest a degree of continuity in the groups that populated this region. In sum, the most important behavioral changes observed in AH III are more intensive site-use, increased movement of obsidian, and the appearance of bone tools and shell beads.

It is important to note that occupation of the site was always episodic. Single fireplaces in AH VI suggest that people used the site occasionally, while the more complex combustion features of AH III support occupations of longer duration. The lithic industry is focused mainly on a single mode of production, and the fauna is diverse. Based on the data presented, we propose that Aghitu-3 served as a hunting camp, perhaps a seasonal base during warmer months of the year. We plan to address the question of seasonality in future studies. We argue that the high elevation of the site makes winter occupation less suitable, as winter snowcover would reduce the frequency of game. Furthermore, the region's steep altitudinal gradient allows people and animals to reach lower and thus warmer altitudes through relatively shortdistance movements, which are, in fact, considerably shorter than the distances shown by the transport of obsidian and shell beads.

\section{Regional comparison}

The earliest evidence for UP behavior at Aghitu-3 Cave suggests sporadic human presence in AH VII and VI and occurs under relatively warm and humid climatic conditions between 39 and $32,000 \mathrm{cal}$ BP. This period is associated with the last phase of the interstadial MIS 3 (57-29,000 BP), as seen in the northern hemisphere, although our data do not permit direct correlation with marine or ice core records. Settlement intensity increases during the next phase of human occupation in AH III from 29 to 24,000 BP as the climate cooled. This period coincides with the beginning of the last glacial cycle, MIS 2 (29-14,000 BP) and marks the beginning of the Last Glacial Maximum (LGM) dated from 26,500 to 20-19,000 BP by Clark et al. (2009).

Regional climatic records from Lake Urmia (Djamali et al., 2012; Stevens et al., 2012), Lake Van (Çağatay et al., 2014; Kwiecien et al., 2014; Stockhecke et al., 2016; Randlett et al., 2017), and the Black Sea region (Kwiecien et al., 2009; Rowe et al., 2012; Wegwerth et al., 2016) support this and generally point to cool conditions with greater seasonality of precipitation. The presence of northern ice sheets during insolation minima contributed to a southerly shift in the westerlies from about 60 to 20,000 BP. As a result, the suppression of precipitation is often noted and associated with changes in vegetation cover (Ünal-Ímer et al., 2015; Stockhecke et al., 2016).

Placing the assemblages from Aghitu-3 into established schemes for classifying the UP is not a straightforward matter. Compared to European and Levantine sites, the technology of Aghitu-3 does not resemble classic industries, although the "laminarity" of the Aghitu3 assemblage does not appear out of place within a UP framework. The dominance of laterally retouched bladelets, followed by backed bladelets, generally corresponds to a UP framework, but the typologies remain noticeably different. We do not observe the hallmarks of either Aurignacian or Gravettian industries, although we do not expect such distant regions to correlate with one another. Instead, we search for clues in adjacent regions.

Looking at the Imereti region of Georgia located $\sim 350 \mathrm{~km} \mathrm{NW}$, we see some parallels. For example, at Ortvale Klde (Adler et al., 2008), the early UP Layers 4 (40-26,000 cal BP) and 3 (26-22,000 cal BP) are of ages similar to Aghitu-3 and offer a workable comparison. The authors describe the lithic assemblage from Layer 4 as containing "unidirectional blade cores, end scrapers on blades, rounded flake scrapers, burins on truncation, numerous retouched bladelets (some $2-3 \mathrm{~mm}$ wide), and backed bladelets" (Adler et al., 2008, p. 819). The last two items on this list are the most common finds at Aghitu-3. However, the bone industry at Ortvale Klde contains bevel-based points, abraders, and a bone implement with incisions, a toolkit that differs from Aghitu-3.

Dzudzuana Units D (35-32,000 cal BP) and C (27-24,000 cal BP) offer perhaps the best comparison to Aghitu-3 (Bar-Yosef et al.,

Table 21

Calculation of settlement intensity using lithics based on artifact density and averaged over time.

\begin{tabular}{|c|c|c|c|c|c|c|c|c|}
\hline Layer & $\begin{array}{l}\text { Thickness } \\
\text { range }(\mathrm{cm})\end{array}$ & $\begin{array}{l}\text { Thickness } \\
\text { average }(\mathrm{m})\end{array}$ & $\begin{array}{l}\text { Excavated } \\
\text { area }\left(\mathrm{m}^{2}\right)\end{array}$ & $\begin{array}{l}\text { Time } \\
\text { range }(k a)\end{array}$ & $\begin{array}{c}\text { Time } \\
\operatorname{span}(k a)\end{array}$ & Lithics $(n)$ & $\begin{array}{l}\text { Lithic density } \\
\quad\left(\text { per } \mathrm{m}^{3}\right)\end{array}$ & $\begin{array}{l}\text { Time averaged lithic } \\
\text { density (per } \mathrm{m}^{3} \text { per ka) }\end{array}$ \\
\hline AH III & $50-100$ & 0.75 & 40 & $29-24,000$ & 5 & 4452 & 148.4 & 29.7 \\
\hline AH IV & $55-100$ & 0.78 & 12 & $30-29,000$ & 1 & 5 & 0.5 & 0.5 \\
\hline $\mathrm{AH} \mathrm{V}$ & $20-30$ & 0.25 & 12 & $32-30,000$ & 2 & 13 & 4.3 & 2.2 \\
\hline $\mathrm{AH}$ VI & $200-250$ & 2.25 & 12 & $36-32,000$ & 4 & 355 & 13.1 & 3.3 \\
\hline AH VII & $100-150$ & 1.25 & 6 & $39-36,000$ & 3 & 155 & 20.7 & 6.9 \\
\hline
\end{tabular}


2011). The assemblage from Unit D has distinctive tool forms represented by rounded end scrapers and dihedral burins. However, unlike Aghitu-3, obsidian is represented by only 3\% of the stone artifacts. Bone tools are present, including three awls and nine points, as well as a decorated piece and an antler bi-point. Unit D does not appear that similar to Unit C, but the latter unit parallels AH III of Aghitu-3. In Unit C, the authors describe a lithic assemblage focused on the manufacture of small blades and bladelets from carinated narrow unidirectional cores. Tools include a diverse array of scrapers and burins, with $4 \%$ made out of obsidian. Retouched bladelets dominate, while typical Aurignacian tools are lacking. The authors emphasize the unique presence of a small number of Sakajia points in Dzudzuana C, “....arched/curved pointed blades with abrupt retouch (but never bipolar) along the straight edge and a proximal retouched truncation [...] removed from unidirectional cores" (Bar-Yosef et al., 2011, p. 339), which are reminiscent of Gravette points but differ technologically. Two decorated stone pendants are present, as is a collection of worked bone, including decorated bones, polished pieces, and perforated teeth. The presence of an eyed needle in Unit $C$ is also noteworthy. Thus, starting at $\sim 29,000$ cal BP, we note a degree of cultural convergence between the two regions. In fact, Bar-Yosef et al. (2011, p. 344) state: "We are lucky to have clear chronological gaps, indicating the various periods during which the cave was occupied. At the same time, one can see continuity of a local tradition in the lithic techno-typological properties [italics added for emphasis]."

The site of Satsurblia in Georgia completes the Georgian UP sequence with evidence of occupation from Layers $\mathrm{B} / \mathrm{III}$ and $\mathrm{B} / \mathrm{II}$ at 26-24,000 cal BP, as well as from Layers A/IIb and A/IIa from 18 to 16,000 cal BP (Pinhasi et al., 2014). Chronologically, B/III and B/II correlate well with AH III of Aghitu-3, while A/IIb and A/IIa overlap with Kalavan-1 (Montoya et al., 2013). A gap in occupation at Satsurblia during the LGM, which Pinhasi et al. (2014) define from 24.4 to $17.9 \mathrm{ka}$ cal BP, is mirrored by an apparent lack of settlement across the region. In Layers $\mathrm{B} / \mathrm{III}$ and $\mathrm{B} / \mathrm{II}$, retouched and backed bladelets dominate, with many burins and end scrapers. The assemblage contains mostly unidirectional and some bidirectional bladelet cores, many of them highly reduced. The technology of $B /$ III and B/II compares favorably with AH III of Aghitu-3. Raw material is mostly poor quality chert with rare occurrences of obsidian. Pinhasi et al. (2014) caution that only the general technotypological trend should be considered because of the small sample size of some layers and possible mixing of Chalcolithic finds within the Paleolithic layers.

With regard to lithic raw material, chert predominates at the Georgian sites. In fact, in all of the examples cited, obsidian appears to be an infrequent material, despite the relative proximity of obsidian in southern Georgia (e.g., the Chikiani/Paravani source) and northwestern Armenia. This may suggest that Paleolithic populations in Georgia maintained fewer long-distance contacts than their southern counterparts. We postulate that this difference may be related to environmental constraints imposed by altitude. Much of the territory of Armenia lies between 1000 and $2000 \mathrm{~m}$, whereas the Georgian sites are much lower at $\sim 300-500 \mathrm{~m}$. Thus, Georgian UP populations might have had access to a more stable variety of locally available resources which reduced their need for long-distance mobility and/or social networks.

Looking to the south, we note several Early UP sites in Iran, Iraq, and central Syria dating between 40 and 35,000 cal BP. Many of these sites are quite distant, some over $1000 \mathrm{~km}$ away. Moreover, the increasingly arid conditions to the south show little resemblance to the Armenian Highlands. At Shanidar, about $350 \mathrm{~km} \mathrm{SW}$ of Aghitu-3, the lithic industry of Layer C is flake-based, consisting of burins, carinated pieces, side scrapers, and points (Olszewski and Dibble, 1994). While Shanidar is as close as the Georgian sites, it does not resemble the bladelet-dominated assemblage of Aghitu-3. However, at Umm el Tlel in central Syria, about 800 km SW, Boëda et al. (2015) report the production of bladelets in Facies 3. They describe an intermediate industry (between MP and UP), where blank production occurs from Levallois and platform cores, and triangular products are present. While Levallois technology and triangular products are unknown from Aghitu-3, the high degree of laminarity resembles AH III, as does the toolkit of retouched bladelets, which the authors show were variously hafted. At Warwasi Rockshelter in Iran, about $700 \mathrm{~km} \mathrm{~S}$, the division of the Zagros Aurignacian into an early and a late entity (see Olszewski, 2001) also seems to have less bearing on our observations from the Armenian Highlands. While the early division is more flake dominated, the late division seems to show links to European and Levantine assemblages, neither of which is apparent in Armenia. Likewise, recent studies at sites such as Yafteh Cave, Ghar-e Boof Cave, and Garm Roud 2 open-air site (Chevrier et al., 2006; Otte et al., 2011, 2012; Tsanova, 2013; Ghasidian, 2014) reveal a greater affiliation to Warwasi in terms of both typology and technology.

\section{Conclusion}

Adler et al. (2008) state that the Caucasus region was likely devoid of Mousterian occupation when UP humans appeared $\sim 42-40,000$ cal BP. However, no sites currently document an actual MP-UP "transition." We note that the first appearances of UPassociated behaviors occur almost simultaneously in Armenia, Georgia, Iran, Iraq, and central Syria, suggesting a rapid expansion of the first UP people into the region.

We argue that the finds from Aghitu-3 in the Armenian Highlands represent a cultural entity that differs from those present in Europe and the Levant at the same time. We resist the tendency to name a new material "culture" or recycle existing classification schemes. Instead, we name the first UP industries from AH VII-VI "Early UP" and the later ones from AH III "Middle UP" (see Gasparyan and Arimura, 2014). At Aghitu-3, we see stronger affinities to the UP of Georgia and central Syria, but fewer similarities compared to the UP sites of Iran and Iraq. We hope that future research will help to clarify regional connections.

The unparalleled record from Aghitu-3 offers a unique view into the first 15,000 years of the UP coupled with a multi-proxy perspective on climate change (Table 22). The record at Aghitu-3 documents the presence of UP people by 39,000 cal BP, a time when climatic conditions were more similar to today. Starting at $\sim 32,000$ cal BP, we see a gradual transition to increasingly colder and drier climatic conditions, and these conditions predominate after $\sim 29,000$ cal BP. Besides the hint of bidirectional reduction technology at the beginning of the sequence, lithic technology remains remarkably constant throughout the sequence. The most notable behavioral changes in AH III coincide with the onset of a cold, dry period and include more intense site-use with frequent combustion features, long-distance transport of obsidian, and the advent of bone tools and shell beads.

These behavioral changes reflect an increase in the movements of individual groups across the landscape into varied ecological zones, coupled with the creation and maintenance of more sophisticated social networks. This suggests that population density increased or, at least, that groups came into contact more frequently. Indeed, more social interaction may be the mechanism behind some of the behavioral changes seen. The cold, dry climate did not hinder human occupation of the Armenian Highlands. We hypothesize that seasonal movements to lower elevations may have been part of the settlement system and, thus, a potential behavioral adaptation to steep climatic and ecological gradients. Archaeologists should focus future efforts on prospecting for sites 
Table 22

Summary of ecological data relating to climate and environment.

\begin{tabular}{|c|c|c|c|c|c|c|c|c|}
\hline Layer & $\begin{array}{l}\text { Date ka } \\
\text { cal BP }\end{array}$ & Macrofauna & Micromammals & Fish & Reptiles/amphibians & Birds & Charcoal & Pollen (sample\#) \\
\hline $\begin{array}{l}\text { AH IIla-b } \\
\quad \text { (upper) }\end{array}$ & $26-24$ & $\begin{array}{l}\text { Most fauna; } \\
\text { Ovis/Capra, } \\
\text { equids }\end{array}$ & $\begin{array}{l}\text { More pika; few hamsters; not as cold; } \\
\text { moderate fragmentation; }\end{array}$ & $\begin{array}{l}\text { Fish up to } 40 \mathrm{~cm} \text {; } \\
\text { probable accumulation } \\
\text { by humans }\end{array}$ & $\begin{array}{l}\text { Open and dry, } \\
\text { mountainous steppe } \\
\text { and rocky }\end{array}$ & $\begin{array}{l}\text { Small sample, no clear } \\
\text { signal }\end{array}$ & $\begin{array}{l}\text { Greatest diversity of } \\
\text { firewood; Salix and } \\
\text { Tamarix peak; } \\
\text { Hippophae lowest }\end{array}$ & - \\
\hline $\begin{array}{l}\text { AH IIIc-d } \\
\quad \text { (lower) }\end{array}$ & $29-26$ & $\begin{array}{l}\text { Most fauna; } \\
\text { Ovis/Capra, } \\
\text { equids }\end{array}$ & $\begin{array}{l}\text { Most pika; few hamsters; maximum } \\
\text { cooling; fragile parts preserved; low } \\
\text { fragmentation }\end{array}$ & $\begin{array}{l}\text { Fish up to } 40 \mathrm{~cm} \text {; } \\
\text { probable accumulation } \\
\text { by humans }\end{array}$ & $\begin{array}{l}\text { Open and dry, } \\
\text { mountainous steppe } \\
\text { and rocky }\end{array}$ & $\begin{array}{l}\text { Small sample, no clear } \\
\text { signal }\end{array}$ & $\begin{array}{l}\text { Hippophae dominates; } \\
\text { Salix and Tamarix } \\
\text { decline }\end{array}$ & - \\
\hline AH IV & $30-29$ & Least fauna & $\begin{array}{l}\text { More pika; few hamster; most species } \\
\text { present; gradual cooling; mostly } \\
\text { mandibles \& molars; low fragmentation; } \\
\text { high deposition; reduced human presence }\end{array}$ & - & - & $\begin{array}{l}\text { Small sample, no clear } \\
\text { signal }\end{array}$ & $\begin{array}{l}\text { Hippophae dominates; } \\
\text { Salix and Tamarix } \\
\text { decline }\end{array}$ & $\begin{array}{l}\text { Qualitative data, } \\
\text { cooling trend, } \\
\text { moisture unclear }(5,6)\end{array}$ \\
\hline AH V & $32-30$ & Least fauna & $\begin{array}{l}\text { Few pika; most species present; gradual } \\
\text { cooling; mostly mandibles \& molars; low } \\
\text { fragmentation; high deposition, reduced } \\
\text { human presence }\end{array}$ & - & - & $\begin{array}{l}\text { Small sample, no clear } \\
\text { signal }\end{array}$ & $\begin{array}{l}\text { Hippophae dominates; } \\
\text { Salix and Tamarix } \\
\text { decline }\end{array}$ & $\begin{array}{l}\text { Qualitative data, cool } \\
\text { and humid (15) }\end{array}$ \\
\hline AH VI & $36-32$ & $\begin{array}{l}\text { More fauna; } \\
\text { Ovis/Capra, } \\
\text { fewer equids }\end{array}$ & $\begin{array}{l}\text { Few pika; moderate gradual cooling, but } \\
\text { still warm; fragmentation }\end{array}$ & - & - & $\begin{array}{l}\text { Temperate, relatively } \\
\text { open landscape; } \\
\text { shallow fresh water in } \\
\text { vicinity of site }\end{array}$ & Hippophae peaks & $\begin{array}{l}\text { Temperate, fairly } \\
\text { humid climate }(20,40 \text {, } \\
41)\end{array}$ \\
\hline AH VII & 39-36 & $\begin{array}{l}\text { Few fauna; } \\
\text { Ovis/Capra, } \\
\text { equids }\end{array}$ & $\begin{array}{l}\text { Mole vole, but few pika; near-modern } \\
\text { climatic conditions; moderate } \\
\text { fragmentation; lower VII lag - high } \\
\text { deposition, reduced human presence }\end{array}$ & $\begin{array}{l}\text { Fish up to } 30 \mathrm{~cm} \text { in lag } \\
\text { deposit; natural } \\
\text { accumulation }\end{array}$ & $\begin{array}{l}\text { Open and dry, } \\
\text { mountainous steppe } \\
\text { and rocky }\end{array}$ & $\begin{array}{l}\text { Temperate, relatively } \\
\text { open landscape; } \\
\text { possible rocky } \\
\text { outcrops; sparse shrub } \\
\text { vegetation; shallow } \\
\text { fresh water, riparian } \\
\text { vegetation in vicinity of } \\
\text { site; possible reed beds }\end{array}$ & $\begin{array}{l}\text { Hippophae dominates; } \\
\text { Nitraria peaks }\end{array}$ & - \\
\hline
\end{tabular}


in the surrounding lower-lying areas of Armenia (Goris, Kapan and Meghri Districts), Artsakh (Nagorno-Karabakh), Azerbaijan, and Iran. These regions may offer further clues, but for now, Aghitu-3 remains the earliest evidence for the presence of UP humans in the Armenian Highlands.

\section{Acknowledgments}

We thank the Director of the Institute of Archaeology and Ethnography of the Armenian National Academy of Sciences, Dr. Pavel Aretisyan, for his help in getting this project off the ground. Without financial and logistical assistance from this organization, we could not have conducted field work or collected data in the laboratory. The Mayor of Aghitu, Avetis Avetisyan, his family, and excavation assistants from the village were also key in implementing the project. The excavation would not have been possible without the hard work of many students from the University of Tübingen and Yerevan State University, with special thanks to D. Araklyan, T. Bagoyan, H. Haydosyan, S. Kesejyan, M. Schaefers, and D. Zardaryan. Finally we thank three anonymous reviewers for their useful comments which helped improve this manuscript. The excavation was sponsored by the Gfoeller Foundation and the Heidelberg Academy of Sciences and Humanities. In addition, E. Allué received funding for charcoal studies from MINECO/FEDER (CGL 2015-65387-C3-1-P), MINCEO (HAR2016-76760-C3-1-P) and AGAUR (2014SGR900) and thanks Dorian Fuller for access to the reference collection at the archaeobotany lab of the Institute of Archaeology (University College London). V.L. Cullen was funded by a Natural Environment Research Council studentship (NE/J500045/ 1) and thanks V. Smith Johnson (University of Oxford) for help with the acquisition of the major element data. E. Frahm's work was supported by the Department of Archaeology, University of Sheffield, the NARNIA (New Archaeological Research Network for Integrating Approaches to Ancient Material Studies) Project, a Marie Curie network funded by the European Commission and FP7 (Grant Agreement 265010), and the Departments of Anthropology and Earth Sciences, University of Minnesota. B. Gruwier thanks Dr. Tarek Oueslati for help with identification and granting access to the reference collections of Charles-de-Gaulle University Lille 3, H. van der Es, for allowing him to study the bird collections of the Natural History Museum of Rotterdam, and Dr. U. Albarella for sharing his data on P. porzana.

\section{Supplementary Online Material}

Supplementary online material related to this article can be found at http://dx.doi.org/10.1016/j.jhevol.2017.05.010.

\section{References}

Adamian, M.S., Klem, D., 1997. A Field Guide to the Birds of Armenia. American University of Armenia Press, Yerevan.

Adler, D.S., Bar-Yosef, O., Belfer-Cohen, A., Tushabramishvili, N., Boaretto, E. Mercier, N., Valladas, H., Rink, W.J., 2008. Dating the demise: Neandertal extinction and the establishment of modern humans in the southern Caucasus. J. Hum. Evol. 55, 817-833.

Adler, D.S., Yeritsyan, B., Wilkinson, K., Pinhasi, R., Bar-Oz, G., Nahapetyan, S. Mallol, C., Berna, F., Bailey, R., Schmidt, B.A., Glauberman, P., Wales, N., Gasparyan, B., 2012. The Hrazdan Gorge Palaeolithic project, 2008-2009. In: Avetisyan, P., Bobokhyan, A. (Eds.), Archaeology of Armenia in Regional Context, Proceedings of the International Conference dedicated to the 50th Anniversary of the Institute of Archaeology and Ethnography Held on September 15-17, 2009 in Yerevan. National Academy of Sciences of the Republic of Armenia, Gitutyun Publishing House, Yerevan, pp. 21-37.

Adler, D.S., Wilkinson, K., Blockley, S., Mark, D., Pinhasi, R., Schmidt-Magee, B., Nahapetyan, S., Mallol, C., Berna, F., Glauberman, P., Raczynski-Henk, Y., Cullen, V., Frahm, E., Jöris, O., Macloud, A., Smith, V., Gasparyan, B., 2014. Early Levallois technology and the transition from the Lower to Middle Palaeolithic in the Southern Caucasus. Science 345, 1609-1613.
Akramovski, N.N., 1976. Fauna Armyanskoy SSR: Molluski. (Fauna of the Armenian SSR: Mollusca). Izdatel'stvo akademii nauk Armyanskoy SSR. Publications of the Armenian Academy of Sciences, Yerevan, Yerevan (in Russian).

Allué, E., Cabanes, D., Solé, A., Sala, R., 2012. Hearth functioning and forest resource exploitation based on the archaeobotantical assemblage from level J of Abric Romaní. In: Carbonell, E. (Ed.), High Resolution Archaeology and Neanderthal Behavior: Time and Space in Level J of Abric Romaní (Capellades, Spain). Springer, Dordrecht, pp. 135-158.

Allué, E., Solé, A., Burguet-Coca, A., 2017. Fuel exploitation among Neanderthals based on the anthracological record from Abric Romaní (Capellades, NE Spain). Quatern. Int. 431A, 6-15.

Andrews, P., 1990. Owls, Caves and Fossils: Predation, Preservation and Accumulation of Small Mammal Bones in Caves, with an Analysis of the Pleistocene Cave Faunas from Westbury-sub-Mendip, Somerset, UK. University of Chicago Press, Chicago.

Arutyunyan, E.V., Lebedev, V.A., Chernyshev, I.V., Sagatelyan, A.K., 2007. Geochronology of Neogene-Quaternary volcanism of the Geghama Highland (Lesser Caucasus, Armenia). Dokl. Akad. Nauk 416, 91-95.

Aslanian, S., Belyaeva, E., Kolpakov, E., Luybin, V., Suvorov, A., 2006. Stone Age in northern Armenia. Antiquity 80, 308 gallery. http://antiquity.ac.uk/projgall/ aslanian308/.

Asouti, E., Austin, P., 2005. Woodland vegetation and its exploitation by past societies, based on the analysis and interpretation of archaeological wood charcoal macro-remains. Environmental Archaeology 10, 1-18.

Auffermann, B., Burkert, W., Hahn, J., Pasda, C., Simon, U., 1990. Ein Merkmalsystem zur Auswertung von Steinartefaktinventaren. Arch. Korrbl. 20, 259-268.

Bar-Oz, G., Adler, D.S., 2005. Taphonomic history of the Middle and Upper Palaeolithic faunal assemblage from Ortvale Klde, Georgian Republic. J. Taphon. 3, 185-211.

Bar-Oz, G., Weissbrod, L., Gasparian, B., Nahapetyan, S., Wilkinson, K., Pinhasi, R. 2012. Taphonomy and zooarchaeology of a high-altitude Upper Pleistocene faunal sequence from Hovk-1 Cave, Armenia. J. Archaeol. Sci. 39, 2452-2463.

Bar-Yosef, O., Belfer-Cohen, A., Adler, D.S., 2006. The implications of the MiddleUpper Paleolithic chronological boundary in the Caucasus to Eurasian prehistory. Anthropologie 44, 49-60.

Bar-Yosef, O., Belfer-Cohen, A., Mesheviliani, T., Jakeli, N., Bar-Oz, G., Boaretto, E. Goldberg, P., Kvavadze, E., Matskevich, Z., 2011. Dzudzuana: an Upper Palaeolithic cave site in the Caucasus foothills (Georgia). Antiquity 85, 331-349.

Benkova, V., Schweingruber, F.H., 2004. Russian Wood Anatomy. Paul Haupt, Bern.

Bickel-Sandkötter, S., Kiefer, K., 2001. Nutzpflanzen und ihre Inhaltsstoffe. Quelle \& Meyer Verlag, Wiebelsheim.

Boëda, E., Bonilauri, S., 2006. The intermediate paleolithic: the first bladelet production 40,000 years ago. Anthropologie 44(1), 75-92.

Boëda, E., Bonilauri, S., Kaltnecker, E., Valladas, H., Al-Sakhel, H., 2015. Un débitage lamellaire au Proche-Orient vers 40000 ans cal BP. Le site d'Umm el Tlel, Syrie centrale. L'anthropologie 119, 141-169.

Bohn, U., Gollub, G., Hettwer, C., Neuhäuslová, Z., Raus, T., Schlüter, H., Weber, H., 2004. Map of the Natural Vegetation of Europe, EuroVegMap 1.01. German Federal Agency for Nature Conservation, Bonn.

Brain, C.K., 1974. Some suggested procedures in the analysis of bone accumulations from southern African Quaternary sites. Annls. Transv. Mus. 29, 1-8.

Bronk Ramsey, C., 2013. Recent and planned developments of the program OXCAL Radiocarbon 55, 720-730.

Bullock, P., Fedoroff, N., Jongerius, A., Stoops, G., Tursina, T., 1985. Handbook for Soil Thin Section Description. Waine Research Publications, Wolverhampton, UK.

Cağatay, M.N., Öğretmen, N., Damcı, E., Stockhecke, M., Sancar, Ü., Eriș, K.K. Ozeren, S., 2014. Lake level and climate records of the last $90 \mathrm{ka}$ from the Northern Basin of Lake Van, eastern Turkey. Quaternary Sci. Rev. 104, 97-116.

Čermák, S., Obuch, J., Benda, P., 2006. Notes on the genus Ochotona in the Middle East (Lagomorpha: Ochotonidae). Lynx (Praha) 37, 51-66.

Chabal, L., Fabre, L., Terral, J.F., Théry-Parisot, I., 1999. L'anthracologie. In: Ferdière, A (Ed.), La Botanique. Editions Errance, Paris, pp. 43-104.

Chataigner, C., 2003. Rapporte scientifique sur les opérations effectuées dans 2003 par la Mission Caucase. Annual report submitted to the Department of Archaeology and Ethnography of the National Academy of Sciences.

Chevrier, B., Berillon, G., Asgari-Khaneghah, A., Antoine, P., Bahain, J.-J., Zeitoun, V., 2006. Moghanak, Otchounak, Garm Roud 2: nouveaux assemblages paléolithiques dans le nord de l'Iran. Premières caractérisations typotechnologiques et attributions chrono-culturelles. Paléorient 32, 59-79.

Chiej, R., 1984. Encyclopaedia of Medicinal Plants. MacDonald \& Co, London.

Clark, P.I., Dyke, A.S., Shakun, J.D., Carlson, A.E., Clark, J., Wohlfarth, B. Mitrovica, J.X., Hostetler, S.W., McCabe, A.M., 2009. The Last Glacial Maximum. Science 325, 710-714.

Climate-data.org, 2017. Published on the Internet. http://climate-data.org (last accessed on 11 Apr. 2017).

Courty, M.A., Goldberg, P., Macphail, R.I., 1989. Soils and Micromorphology in Archaeology. Cambridge University Press, Cambridge.

Davis, M.K., Jackson, T.L., Shackley, M.S., Teague, T., Hampel, J.H., 2011. Factors affecting the energy-dispersive X-ray fluorescence (EDXRF) analysis of archaeological obsidian. In: Shackley, M.S. (Ed.), X-Ray Fluorescence Spectrometry (XRF) in Geoarchaeology. Springer, New York, pp. 45-63.

Dibble, H.L., McPherron, S.P., 1996. A Multimedia Companion to the Middle Paleolithic Site of Combe-Capelle Bas (France). University of Pennsylvania Museum, Philadelphia. 
Djamali, M., de Beaulieu, J.-L., Shah-Hosseini, M., Andrieu-Ponel, V., Amini, A., Akhani, H., Leroy, S.A.G., Stevens, L., Alizadeh, H., Ponel, P., Brewer, S., 2008. A late Pleistocene long pollen record from Lake Urmia, NW Iran. Quatern. Res. 69, 413-420.

Djamali, M., Baumel, A., Brewer, S., Jackson, S.T., Kadereit, J.W., LópezVinyallonga, S., Mehregan, I., Shabanian, E., Simakova, A., 2012. Ecological implications of Cousinia Cass. (Asteraceae) persistence through the last two glacial-interglacial cycles in the continental Middle East for the Irano-Turanian flora. Rev. Palaeobot. Palyno. 172, 210-220.

Dolukhanov, P., Aslanian, S., Kolpakov, E., Belyaeva, E., 2004. Prehistoric Sites in Northern Armenia. Antiquity 78, gallery 301. http://antiquity.ac.uk/projgall/ dolukhanov301/.

Egeland, C.P., Nicholson, C.M., Gasparian, B., 2010. Using GIS and ecological variables to identify high potential areas for paleoanthropological survey: An example from Northern Armenia. J. Ecol. Anthropol. 14, 89-98.

Ericson, P.G.P., 1987. Interpretations of archaeological bird remains: a taphonomic approach. J. Archaeol. Sci. 14, 65-75.

Fahn, A., Werker, E., Baas, P., 1986. Wood Anatomy and Identification of Trees and Shrubs from Israel and Adjacent Regions. The Israel Academy of Sciences and Humanities, Jerusalem.

Floss, H. (Ed.), 2013. Steinartefakte: vom Altpaläolithikum bis in die Neuzeit, 2nd ed. Kerns Verlag, Tübingen.

Forster, N., Grave, P., Vickery, N., Kealhofer, L., 2011. Non-destructive analysis using PXRF: methodology and application to archaeological ceramics. X-Ray Spectrom. 40, 389-398.

Frahm, E., 2014. Characterizing obsidian sources with portable XRF: accuracy, reproducibility, and field relationships in a case study from Armenia. J. Archaeol. Sci. 49, 105-125.

Frahm, E., 2016. Can I get chips with that? Obsidian sourcing down to the microdebitage with portable XRF. J. Archaeol. Sci. Reports 9, 448-467.

Frahm, E., Feinberg, J.M., 2015. Reassessing obsidian field relationships at Glass Buttes. Oregon. J. Archaeol. Sci. Reports 2, 654-665.

Frahm, E., Schmidt, B., Gasparyan, B., Yeritsyan, B., Karapetian, S., Meliksetian, K., Adler, D.S., 2014. Ten seconds in the field: Rapid Armenian obsidian sourcing with portable XRF to inform excavations and surveys. J. Archaeol. Sci. 41, 333-348.

Frahm, E., Feinberg, J.M., Schmidt-Magee, B., Wilkinson, K.N., Gasparyan, B., Yeritsyan, B., Adler, D.S., 2016. Middle Palaeolithic lithic procurement behaviors at Lusakert Cave 1, Hrazdan Valley, Armenia. J. Hum. Evol. 91, 73-92.

Gabunia, L., Vekua, A., Lordkipanidze, D., Swisher III, C.C., Ferring, R., Justus, A., Nioradze, M., Tvalchrelidze, M., Anton, S.C., Bosinski, G., Jöris, O., de Lumley, M.A., Majsuradze, G., Mouskhelishvili, A., 2002. Earliest Pleistocene hominid cranial remains from Dmanisi, Republic of Georgia: Taxonomy, geological setting, and age. Science 288, 1019-1025.

Galbreath, K.E., Hafner, D.J., Zamudio, K.R., 2009. When cold is better: climatedriven elevation shifts yield complex patterns of diversification and demography in an alpine specialist (American pika, Ochotona princeps). Evolution 63, 2848-2863.

Gasparyan, B.,Arimura, M. 2014. Study of the Stone Age in the Republic of Armenia: Achievements and perspectives. In: Gasparyan, B., Arimura, M. (Eds.), Stone Age of Armenia: A Guide-Book to the Stone Age Archaeology in the Republic of Armenia. Center for Cultural Resource Studies, Kanazawa University, Kanazawa, pp. 13-36.

Gasparyan, B., Adler, D.S., Egeland, C.P., Azatyan, K., 2014a. Recently discovered Lower Paleolithic Sites of Armenia. In: Gasparyan, B., Arimura, M. (Eds.), Stone Age of Armenia: A Guide-Book to the Stone Age Archaeology in the Republic of Armenia. Center for Cultural Resource Studies, Kanazawa University, Kanazawa, pp. 37-64.

Gasparyan, B., Egeland, C.P., Adler, D.S., Pinhasi, R., Glauberman, P., Haydosyan, H., 2014b. The Middle Paleolithic occupation of Armenia: Summarizing old and new data. In: Gasparyan, B., Arimura, M. (Eds.), Stone Age of Armenia: A Guide-Book to the Stone Age Archaeology in the Republic of Armenia. Center for Cultural Resource Studies, Kanazawa University, Kanazawa, pp. 65-106.

Gasparyan, B., Kandel, A.W., Montoya, C., 2014c. Living the high life: the Upper Paleolithic settlement of the Armenian highlands. In: Gasparyan, B., Arimura, M. (Eds.), Stone Age of Armenia: A Guide-Book to the Stone Age Archaeology in the Republic of Armenia. Center for Cultural Resource Studies, Kanazawa University, Kanazawa, pp. 107-131.

Ghasidian, E., 2014. The Early Upper Paleolithic Occupation at Ghar-e Boof Cave: A Reconstruction of Cultural Tradition in the Southern Zagros Mountains of Iran. Kerns Verlag, Tübingen.

Ghukasyan, R., Colonge, D. Nahapetyan, S., Ollivier, V., Gasparyan, B., Monchot, H., Chataigner, C., 2011. Kalavan-2 (North of Lake Sevan, Armenia): A new late Middle Paleolithic site in the Lesser Caucasus. Archaeology, Ethnology and Anthropology of Eurasia 38, 39-51.

González-Sampériz, P., Leroy, S.A.G., Carrión, J.S., Fernández, S., García-Antón, M., Gil-García, M.J., Uzquiano, P., Valero-Garcés, B., Figueiral, I., 2010. Steppes, savannahs, forests and phytodiversity reservoirs during the Pleistocene in the Iberian Peninsula. Rev. Palaeobot. Palyno. 162, 427-457.

Grimm, E.C., 2004. TILIA and TG View 2.0.2. Illinois State Museum, Springfield, USA.

Hahn, J., 1977. Aurignacien: Das Altere Jungpaläolithikum in Mittel- und Osteuropa. Böhlau Verlag, Köln.

Hahn, J., 1993. Erkennen und Bestimmen von Stein- und Knochenartefakten: Einführung in die Artefaktmorphologie, 2nd ed. Verlag Archaeologica Venatoria, Tübingen.
Inizan, M.-L., Reduron-Ballinger, M., Roche, H., Tixier, J., 1999. Préhistoire de la Pierre Taillée, Vol. 5, Technology and Terminology of Knapped Stone. Cercle de Recherches et d'Etudes Préhistoriques, Nanterre.

InsideWood, 2004-onwards. Published on the Internet. http://insidewood.lib.ncsu. edu/search (last accessed on 28 Jan. 2016).

International Union for Conservation of Nature, 2015. The IUCN Red List of Threatened Species. Version 2015-4. http://www.iucnredlist.org (last accessed on 28 Jan. 2016).

Jansen, S., Piesschaert, F., Smets, E., 2000. Wood anatomy of Elaeagnaceae, with comments on vestured pits, helical thickenings, and systematic relationships. Am. J. Bot. 87, 20-28.

Jochum, K.P., Stoll, B., Herwig, K., Willbold, M., Hofmann, A.W., Amini, M., Aarburg, S., Abouchami, W., Hellebrand, E., Mocek, B., Raczek, I., Stracke, A., Alard, O., Bouman, C., Becker, S., Dücking, M., Brätz, H., Klemd, R., de Bruin, D., Canil, D., Cornell, D., de Hoog C., Dalpé, C., Danyushevsky, L., Eisenhauer, A., Gao, Y., Snow, J.E., Groschopf, N., Günther, D., Latkoczy, C., Guillong, M., Hauri, E., Höfer, H.E., Lahaye, Y., Horz, K., Jacob, D.E., Kasemann, S.A., Kent, A.J.R., Ludwig, T., Zack, T., Mason, P.R.D., Meixner, A., Rosner, M., Misawa, K., Nash, B.P., Pfänder, J., Premo, W.R., Sun, W.D., Tiepolo, M., Vannucci, R., Vennemann, T., Wayne, D., Woodhead, J.D., 2006. MPI-DING reference glasses for in situ microanalysis: new reference values for element concentrations and isotope ratios. Geochem. Geophy. Geosy. 7, Q02008. http://dx.doi.org/10.1029/2005GC001060.

Kandel, A.W., Gasparyan, B., Bruch, A.A., Weissbrod, L., Zardaryan, D., 2011. Introducing Aghitu-3, the first Upper Paleolithic cave site in Armenia. ARAMAZD, Armenian Journal of Near Eastern Studies 6, 7-23.

Kandel, A.W., Gasparyan, B., Nahepetyan, S., Taller, A., Weissbrod, L., 2014. The Upper Paleolithic Settlement of the Armenian Highlands. In: Otte, M. (Ed.), Modes of Contacts and Displacements During the Eurasian Paleolithic. Conference Proceedings, Liège, 29-31 May 2012. ERAUL 140, Luxembourg, pp. 39-60.

Klein, R.G., Cruz-Uribe, K., Beaumont, P., 1991. Environmental, ecological, and paleoanthropological implications of the Late Pleistocene mammalian fauna from Equus Cave, Northern Cape Province, South Africa. Quatern. Res. 36, 94-119.

Kolpakov, E.M., 2009. The Late Acheulian site of Dashtadem-3 in Armenia. PaleoAnthropology 2009, 3-31.

Kroll, S., 2006. Southern Armenia Survey (Syunik), 2000-2003 (Achaemenid-Hellenistic Period, Aghitu Fortress, Sisian, 1640m, N39 30'49.7" E46 4'51.2") ARAMAZD, Armenian Journal of Near Eastern Studies 1, 19-49.

Kuiper, M.W., Ottens, H.J., Cenin, L., Schaffers, A.P., van Ruijven, J., Koks, B.J., Berendse, F., de Snoo, G.R., 2013. Field margins as foraging habitat for skylarks (Alauda arvensis) in the breeding season. Agr. Ecosyst. Environ. 170, 10-15.

Kvavadze, E., Kakhiani, K., 2010. Palynology of the Paravani burial mound (Early Bronze Age, Georgia). Veg. Hist. Archaeobot. 19, 469-478.

Kvavadze, E., Bar-Yosef, O., Belfer-Cohen, A., Boaretto, E., Jakeli, N., Matskevich, Z., Meshveliani, T., 2009. 30,000-year-old wild flax fibers. Science 325, 1359.

Kwiecien, O., Arz, H.G., Lamy, F., Plessen, B., Bahr, A., Haug, G.H., 2009. North Atlantic control on precipitation pattern in the eastern Mediterranean/Black Sea region during the last glacial. Ouatern. Res. 71, 375-384.

Kwiecien, O., Stockhecke, M., Pickarski, N., Heumann, G., Litt, T., Sturm, M., Anselmetti, F., Kipfer, R., Haug, G.H., 2014. Dynamics of the last four glacial terminations recorded in Lake Van, Turkey. Quaternary Sci. Rev. 104, 42-52.

Laroulandie, V., 2000. Taphonomie et archéozoologie des oiseaux en grotte: applications aux sites paléolithiques du Bois-Ragot (Vienne), de Combe Saunière (Dordogne) et de La Vache (Ariège). Ph.D. Dissertation, Université de Bordeaux.

Laroulandie, V., 2002. Damage to pigeon long bones in pellets of the eagle owl Bubo bubo and food remains of peregrine falcon Falco peregrinus: Zooarchaeological implications. Acta Zoologica Cracoviensia 45, 331-339.

Lebedev, V.A., Chernyshev, I.V., Sharkov, E.V., 2011. Geochronological scale and evolution of Cenozoic magmatism within the Caucasian segment of the Alpine Belt. Dokl. Earth Sci. 441, 1656-1660.

Liagre, J., Gasparyan, B., Ollivier, V., Nahapetyan, S., 2006. Angeghakot 1 (Armenia) and the identification of the Mousterian cultural facies of "Yerevan points" type in the Southern Caucasus. Paléorient 32, 5-18.

Liu, B., Zhao, W., 2009. Ecological adaptability of photosynthesis and water metabolism for Tamarix ramosissima and Nitraria sphaerocarpa in desert-oasi ecotone. J. Desert Research 29, 101-107.

Lordkipanidze, D., Vekua, A., Ferring, R., Rightmire, G.P., Agusti, J., Kiladze, G., Mouskhelishvili, A., Nioradze, M., Ponce de León, M.S., Tappen, M. Zollikofer, C.P.E., 2005. The earliest toothless hominin skull. Nature 434, 717-718.

Lordkipanadze, D., Ponce de León, M.S., Margvelashvili, A., Rak, Y., Rightmire, G.P., Vekua, A., Zollikofer, C.P. 2013. A complete skull from Dmanisi, Georgia, and the evolutionary biology of early Homo. Science 342, 326-331.

Marquer, L., Otto, T., Nespoulet, R., Chiotti, L., 2010. A new approach to study the fuel used in hearths by hunter-gatherers at the Upper Palaeolithic site of Abri Pataud (Dordogne, France). J. Archaeol. Sci. 37, 2735-2746.

Meriggi, M., Montagna, D., Zacchetti, D., 1991. Habitat use by partridges (Perdix perdix and Alectoris rufa) in an area of Northern Apennines. Italy. Boll. Zool. 58, 85-89.

Montoya, C., Balasescu, A., Joannin, S., Ollivier, V., Liagre, J., Nahapetyan, S., Ghukasyan, R., Colonge, D., Gasparyan, B., Chataigner, C., 2013. The Upper Palaeolithic site of Kalavan 1 (Armenia): An Epigravettian settlement in the Lesser Caucasus. J. Hum. Evol. 65, 621-640.

Mourer-Chauviré, C., 1983. Les oiseaux dans les habitats paléolithiques: Gibier des hommes ou proies des rapaces?. In: Grigson, C., Clutton-Brock, J. (Eds.), Animals 
and Archaeology: Shell Middens, Fishes and Birds. BAR International Series 183, Oxford, pp. 111-124.

Naeem Awan, M., Siddique Awan, M., Basharat, K., 2006. Distribution, status and habitat utilization of Alectoris chukar in Machiara National Park District, Muzaffarabad Azad, Kashmir. J. Agri. Soc. Sci. 2, 230-234.

Nioradze, M.G., Otte, M., 2000. Paléolithique supérieur de Géorgie. L'anthropologie $104,265-300$.

Ollivier, V., Nahapetyan, S., Roiron, P., Gabrielyan, I., Gasparyan, B., Chataigner, C., Joannin, S., Cornée, J.-J., Guillou, H., Scaillet, S., Munch, P., Krijgsman, W., 2010. Quaternary volcano-lacustrine patterns and palaeobotanical data in southern Armenia. Quatern. Res. 223-224, 312-326.

Olszewski, D.I., 2001. Ruminations on the Early Upper Paleolithic and a consideration of the Zagros Aurignacian. In: Hays, M.A., Thacker, P.T. (Eds.), Questioning the Answers: Re-solving Fundamental Problems of the Early Upper Paleolithic. BAR International Series 1005, Oxford, pp. 79-89.

Olszewski, D.I., Dibble, H.L., 1994. The Zagros Aurignacian. Curr. Anthropol. 35, $68-75$.

Otte, M., Shidrang, S., Zwyns, N., Flas, D., 2011. New radiocarbon dates for the Zagros Aurignacian from Yafteh Cave. Iran. J. Hum. Evol. 61, 340-346.

Otte, M., Shidrang, S., Flas, D. (Eds.), 2012. The Aurignacian of Yafteh Cave and Its Context (2005-2008 Excavations). ERAUL 132, Liège.

Palumbi, G., Gratuze, B., Harutyunyan, A., Chataigner, C., 2014. Obsidian-tempered pottery in the Southern Caucasus: a new approach to obsidian as a ceramictemper. J. Archaeol. Sci. 44, 43-54.

Peel, M.C., Finlayson, B.L., McMahon, T.A., 2007. Updated world map of the KöppenGeiger climate classification. Hydrol. Earth Syst. Sci. 11, 1633-1644.

Pinhasi, R., Gasparian, B., Wilkinson, K., Bailey, R., Bar-Oz, G., Bruch, A. Chataigner, C., Hoffmann, D., Hovsepyan, R., Nahapetyan, S., Pike, A.W.G. Schreve, D., Stephens, M., 2008. Hovk 1 and the Middle and Upper Paleolithic of Armenia: a preliminary framework. J. Hum. Evol. 55, 803-816.

Pinhasi, R., Gasparian, B., Nahapetyan, S., Bar-Oz, G., Weissbrod, L., Bruch, A.A., Hovsepyan, R., Wilkinson, K., 2011. Middle Palaeolithic human occupation of the high altitude region of Hovk-1, Armenia. Quaternary Sci. Rev. 30, 3846-3857.

Pinhasi, R., Meshveliani, T., Matskevich, Z., Bar-Oz, G., Weissbrod, L., Miller, C.E. Wilkinson, K., Lordkipanidze, D., Jakeli, N., Kvavadze, E., Higham, T.F.G., BelferCohen, A., 2014. Satsurblia: New insights of human response and survival across the Last Glacial Maximum in the Southern Caucasus. PLOS ONE 9, e111271.

Reimer, P.J., Bard, E., Bayliss, A., Beck, J.W., Blackwell, P.G., Bronk Ramsey, C., Buck, C.E., Cheng, H., Edwards, R.L., Friedrich, M., Grootes, P.M., Guilderson, T.P., Haflidason, H., Hajdas, I., Hatté, C., Heaton, T.J., Hoffmann, D.L., Hogg, A.G., Hughen, K.A., Kaiser, K.F., Kromer, B., Manning, S.W., Niu, M., Reimer, R.W. Richards, D.A., Scott, E.M., Southon, J.R., Staff, R.A., Turney, C.S.M., van der Plicht, J., 2013. IntCal13 and Marine13 radiocarbon age calibration curves 0-50,000 years Cal BP. Radiocarbon 55, 1869-1887.

Randlett, M.-E., Bechtel, A., van der Meer, M.T.J., Peterse, F., Litt, T., Pickarski, N., Kwiecien, O., Stockhecke, M., Wehrli, B., Schubert, C.J., 2017. Biomarkers in Lake Van sediments reveal dry conditions in Eastern Anatolia during $110.000-10.000$ years B.P. Geochem. Geophys. Geosyst. 18, 571-583.

Rowe, P.J., Mason, J.E., Andrews, J.E., Marca, A.D., Thomas, L., van Calsteren, P. Jex, C.N., Vonhof, H.B., Al-Omari, S., 2012. Speleothemisotopic evidence of winter rainfall variability in northeast Turkey between 77 and 6 ka. Quaternary Sci. Rev. 45, 60-72.

Schweingruber, F.H., 1990. Anatomie europäischer Hölzer: ein Atlas zur Bestimmung europäischer Baum-, Strauch- und Zwergstrauchhölzer (Anatomy of European Woods: An Atlas for the Identification of European Trees Shrubs and Dwarf Shrubs). Paul Haupt, Stuttgart.

Schweingruber, W., Landolt, W., 2005. The Xylem Database. Swiss Federal Research Institute WSL. http://www.wsl.ch/dendropro/xylemdb/ (last update $21 \mathrm{Dec}$ 2010, last accessed 7 Jul. 2015.).

Schweingruber, F.H., Börner, A., Schulze, E.-D., 2011. Atlas of Stem Anatomy in Herbs, Shrubs and Trees, Vol. 1. Springer, Berlin.

Solé, A., Allué, E., Carbonell, E., 2013. Hearth-related wood remains from Abric Romaní layer M (Capellades, Spain). J. Anthropol. Res. 69, 535-559.
Stevens, L.R., Djamali, M., Andrieu-Ponel, V., de Beaulieu, J.-L., 2012. Hydroclimatic variations over the last two glacial/interglacial cycles at Lake Urmia. Iran. J. Paleolimnol. 47, 645-660.

Stockhecke, M., Timmermann, A., Kipfer, R., Haug, G.H., Kwiecien, O., Friedrich, T. Menviel, L., Litt, T., Pickarski, N., Anselmetti, F.S., 2016. Millennial to orbital-scale variations of drought intensity in the Eastern Mediterranean. Ouaternary Sci. Rev. 133, 77-95.

Stoops, G., 2003. Guidelines for Analysis and Description of Soil and Regolith Thin Sections. Soil Science Society of America, Madison, WI.

Stuart Baker, E.C., 1922. The game birds of India, Burma and Ceylon, Part 31 J. Bombay Nat. Hist. Soc. 28, 306-312.

Svenson, L., Grant, P.J., 1999. Collins Bird Guide. Collins, London.

Takacsova, M., 2007. On habitat selection of the Marsh Harrier (Circus aeruginosus) in the agricultural region (SW Slovakia, the Danubian lowland). Acta Zoologica Universitatis Comenianae 47, 57-63.

Tsanova, T., 2013. The beginning of the Upper Paleolithic in the Iranian Zagros. A taphonomic approach and techno-economic comparison of Early Baradostian assemblages from Warwasi and Yafteh (Iran). J. Hum. Evol. 65, 39-64.

Théry-Parisot, I., 2001. Économie des Combustibles au Paléolithique. Dossier de Documentation Archéologique, 20. CNRS, Paris.

Théry-Parisot, I., Texier, P.J., 2006. Firewood gathering in the Mousterian site of Combette (Bonnieux, Vaucluse, France): Paleo-economic and paleoecologic implications. Morphometric approach of charcoal wood. Bulletin de la Société Préhistorique Française 103, 453-463.

Tornero, C., Balasse, M., Bălășescu, A., Chataigner, C., Gasparyan, B., Montoya, C., 2016. The altitudinal mobility of wild sheep at the Epigravettian site of Kalavan 1 (Lesser Caucasus, Armenia): Evidence from a sequential isotopic analysis in tooth enamel. J. Hum. Evol. 97, 27-36.

Ünal-Ímer, E., Shulmeister, J., Zhao, J.-X., Uysal, I.T., Feng, Y.-X., Nguyen, A.D. Yüce, G., 2015. An 80 kyr-long continuous speleothem record from Dim Cave, SW Turkey with paleoclimatic implications for the Eastern Mediterranean. Nature Sci. Rep. 5, 13560.

Uzquiano, P., 2014. Wood resource exploitation by Cantabrian Late Upper Palaeolithic groups (N Spain) regarding MIS 2 vegetation dynamics. Quatern. Int. 337, $154-162$.

van Geel, B. (Ed.), 2006. Quaternary non-pollen palynomorphs. Rev. Palaeobot. Palynol. 141, 1-230.

van Vliet-Lanoë, V., Coutard, J.P. Pissart, A., 1984. Structures caused by repeated freezing and thawing in various loamy sediments: a comparison of active, fossil and experimental data. Earth Surf. Proc. Land. 9, 553-565.

Vekua, A., Lordkipanidze, D., Rightmire, G.P., Agusti, J., Ferring, R., Maisuradze, G., Mouskhelishvili, A., Nioradze, M., Ponce de Leon, M., Tappen, M., Tvalchrelidze, M., Zollikofer, C., 2002. A new skull of early Homo from Dmanisi, Georgia. Science 297, 85-89.

Vereshchagin, N.K., 1967. The Mammals of the Caucasus. Israel Program for Scientific Translation, Jerusalem.

Vernet, J.L., 1997. L'homme et la forêt méditerranéenne de la Préhistoire à nos jours. Editions Errance, Paris.

Watson, G.E., 1961. Three sibling species of Alectoris partridge. Ibis 104, 353-367.

Wegwerth, A., Kaiser, J., Dellwig, O., Shumilovskikh, L., Nowaczyk, N.R., Arz, H.W., 2016. Northern hemisphere climate control on the environmental dynamics in the glacial Black Sea "Lake". Quaternary Sci. Rev. 135, 41-53.

Wheeler, E.A., 2011. InsideWood - a web resource for hardwood anatomy. IAWA 32. 199-211.

Willis, K.J., Rudner, E., Sümegi, P., 2000. The full-glacial forests of Central and Southeastern Europe. Quatern. Res. 53, 203-213.

World Wildlife Fund, 2006. WildFinder: Online database of species distributions, ver. Jan-06. http://www.worldwildlife.org/WildFinder (last accessed on 28 Jan. 2016).

Yang, S., Furukawa, I., Jiang, Z., 2010. Anatomical variations in the woody plants of arid areas. In: Ramawat, K.G. (Ed.), Desert Plants. Springer, Heidelberg, pp. 135-155.

Zhang, L.J., Wang, L.J., Nie, X.L., 2007. Comparative anatomical study on wood of three kinds of Hippophae stem. Journal of Jilin Agricultural University 29, 289-292. 